\title{
2014-2015 Offshore Wind Technologies Market Report
}

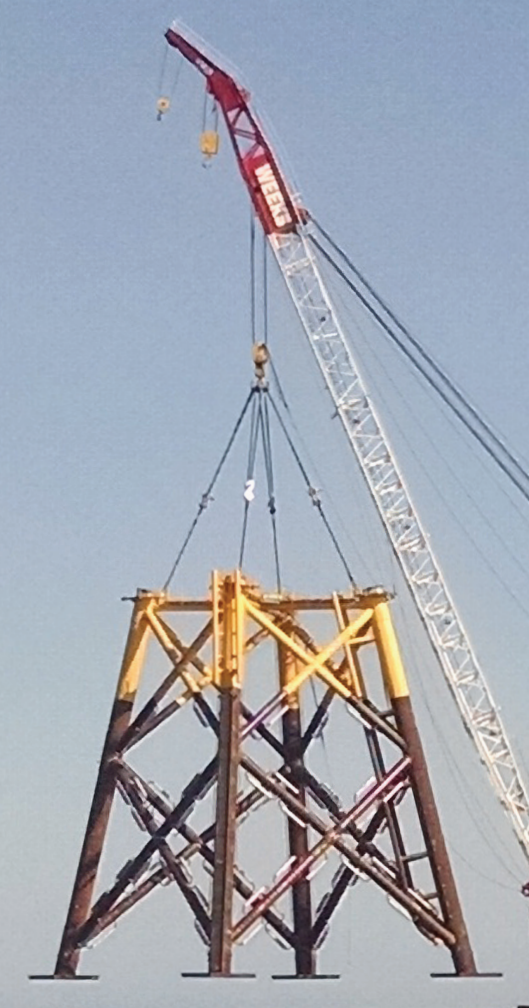

NREL is a national laboratory of the U.S. Department of Energy, Office of Energy Efficiency and

Renewable Energy, operated by the Alliance for Sustainable Energy, LLC. 


\section{4-2015 Offshore Wind Technologies Market Report}

Aaron Smith, Tyler Stehly, and Walter Musial National Renewable Energy Laboratory

Prepared under Task No. WE14.CG02

Link to Data Tables

NREL is a national laboratory of the U.S. Department of Energy Office of Energy Efficiency \& Renewable Energy Operated by the Alliance for Sustainable Energy, LLC

This report is available at no cost from the National Renewable Energy Laboratory (NREL) at www.nrel.gov/publications.

Technical Report

NREL/TP-5000-64283

September 2015 
This report is being disseminated by the U.S. Department of Energy (DOE). As such, this document was prepared in compliance with Section 515 of the Treasury and General Government Appropriations Act for fiscal year 2001 (public law 106-554) and information quality guidelines issued by DOE. Though this report does not constitute "influential" information, as that term is defined in DOE's information quality guidelines or the Office of Management and Budget's Information Quality Bulletin for Peer Review, the study was reviewed both internally and externally prior to publication. For purposes of external review, the study benefited from the advice and comments of seven wind industry and trade association representatives, nine consultants, one academic institution, and five U.S. Government employees.

\section{NOTICE}

This report was prepared as an account of work sponsored by an agency of the United States government. Neither the United States government nor any agency thereof, nor any of their employees, makes any warranty, express or implied, or assumes any legal liability or responsibility for the accuracy, completeness, or usefulness of any information, apparatus, product, or process disclosed, or represents that its use would not infringe privately owned rights. Reference herein to any specific commercial product, process, or service by trade name, trademark, manufacturer, or otherwise does not necessarily constitute or imply its endorsement, recommendation, or favoring by the United States government or any agency thereof. The views and opinions of authors expressed herein do not necessarily state or reflect those of the United States government or any agency thereof.

This report is available at no cost from the National Renewable Energy Laboratory (NREL) at www.nrel.gov/publications.

Available electronically at $\underline{\text { SciTech Connect http:/www.osti.gov/scitech }}$

Available for a processing fee to U.S. Department of Energy and its contractors, in paper, from:

U.S. Department of Energy

Office of Scientific and Technical Information

P.O. Box 62

Oak Ridge, TN 37831-0062

OSTI http://www.osti.gov

Phone: 865.576.8401

Fax: 865.576.5728

Email: reports@osti.gov

Available for sale to the public, in paper, from:

U.S. Department of Commerce

National Technical Information Service

5301 Shawnee Road

Alexandria, VA 22312

NTIS http://www.ntis.gov

Phone: 800.553 .6847 or 703.605 .6000

Fax: 703.605.6900

Email: orders@ntis.gov 


\section{Acknowledgments}

This work was supported by the U.S. Department of Energy (DOE) under Contract No. DEAC36-08GO28308 with the National Renewable Energy Laboratory (NREL). Funding for the work was provided by the DOE Office of Energy Efficiency and Renewable Energy, Wind and Water Power Technologies Office. The authors would like to extend thanks to Mark Higgins from the DOE Wind and Water Power Technologies Office for supporting this research. Thanks also to Jose Zayas, Patrick Gilman, Greg Matzat, Dan Beals, Rich Tusing, Alana Duerr, Gary Norton, and Liz Hartman of the DOE Wind and Water Power Technologies Office for their support and strategic guidance.

NREL would like to recognize the Navigant Consortium, including Navigant Consulting, the American Wind Energy Association, the Great Lakes Wind Collaborative, Green Giraffe Energy Bankers, Ocean and Coastal Consultants (a COWI company), and Tetra Tech EC, Inc. for developing the original market reports for the U.S. offshore wind industry covering 2012 through 2014.

NREL would also like to thank the following reviewers and contributors: Brian Smith, David Corbus, Maureen Hand, Christopher Moné (NREL); Jennifer Golladay, Amy Stillings, Doug Boren, David MacDuffee, Sid Falk (Bureau of Ocean Energy Management); Charles Nordstrom (BVG Associates); Dennis Duffy (Cape Wind); Jeff Grybowski (Deepwater Wind); Thomas Brostrøm, Lise Lotte Lyck, Sune Strøm (DONG Energy); Chris Wissemann (Fishermen's Energy); Feng Zhao and Aris Karcanias (FTI Consulting); Lorry Wagner (LEEDCo); Annette Bossler (Main(e) International Consulting); Aaron Barr and Michael Guldbrandtsen (MAKE Consulting); Brent Cooper (Ocean and Coastal Consultants); Bruce Hamilton and Jesse Broehl (Navigant Consulting); Stephanie McClellan (Special Initiative on Offshore Wind); Michael Ernst (Tetra Tech); and Willett Kempton (Center for Carbon-free Power Integration, University of Delaware).

Graphics, project management, and editing were supplied by Sheri Anstedt, Alex Lemke, Josh Bauer, Al Hicks, and Bryan Bechtold (NREL). 


\section{List of Acronyms}

ATD

BIWF

BLS

BOEM

BPU

CapEx

CFD

COD

CRMF

DOE

EWEA

FID

FIT

GW

HVAC

HVDC

IBGS

$\mathrm{kV}$

$\mathrm{kW}$

LEEDCo

LCOE

LLC

$\mathrm{m}$

METI

MHI

MOE

MW

MWh

N/A

NREL

O\&M

OCS

OEM

OpEx

OREC

ORE

OTM

OWDB

PPA

R\&D

RES

TBA

TBD

TSA

TSO
Advanced Technology Demonstration

Block Island Wind Farm

Bureau of Labor Statistics

Bureau of Ocean Energy Management

Board of Public Utilities (New Jersey)

capital expenditures

contract for difference

commercial operation date

Cost Reduction Monitoring Framework

U.S. Department of Energy

European Wind Energy Association

final investment decision

feed-in tariff

gigawatt

high-voltage alternating current

high-voltage direct current

inward battered guided structure

kilovolt

kilowatt

Lake Erie Energy Development Corporation

levelized cost of energy

Limited Liability Company

meter(s)

Ministry of Economic, Trade and Industry

Mitsubishi Heavy Industries

Minister of Environment

megawatt

megawatt-hour

not applicable

National Renewable Energy Laboratory

operation and maintenance

Outer Continental Shelf

original equipment manufacturer

operational expenditures

offshore renewable energy certificate

Offshore Renewable Energy

offshore transmission module

Offshore Wind Database

power purchase agreement

research and development

Renewable Energy Systems

to be announced

to be determined

turbine supply agreement

Transmission System Operator 
USD

VOWTAP

WACC

WEA
United States dollar

Virginia Offshore Wind Technology Advancement Project weighted average cost of capital

wind energy area 


\section{Executive Summary}

This report provides data and analysis to assess the status of the U.S. offshore wind industry through June 30, 2015. It builds on the foundation laid by the Navigant Consortium, which produced three market reports between 2012 and 2014. The report summarizes domestic and global market developments, technology trends, and economic data to help U.S. offshore wind industry stakeholders, including policymakers, regulators, developers, financiers, and supply chain participants, to identify barriers and opportunities. Key elements from the report are highlighted below.

\section{New Method for Tracking Offshore Wind Projects}

For this report, the National Renewable Energy Laboratory developed a new system for classifying and tracking the progress of projects within the development pipeline. This new framework aims to be generalizable across multiple markets (i.e., internationally) and regulatory regimes (e.g., state versus federal waters) and define discrete life cycle phases to provide an objective way of assessing project status based on measurable milestones. The new classification system divides the offshore wind project life cycle into nine stages: 1) planning - early stage, 2) planning - site control, 3) major permits submitted, 4) approved, 5) financial close, 6) under construction, 7) operating, 8) decommissioned, and 9) on hold/canceled. These stages ensure that every potential project is acknowledged and can be tracked throughout the project life cycle.

\section{Global Offshore Wind Market on Target to Set Annual Deployment Record in 2015}

The global offshore wind industry is poised to set a record for annual installations in 2015 . Although only 1,069 megawatts (MW) of new capacity was installed in 2014, 2015 is expected to be a record year for offshore wind deployments globally, with 3,996 MW on track to begin operations. In the first half of 2015, the industry commissioned 1,190 MW of this capacity, bringing the total current installed capacity to $8,990 \mathrm{MW}$ worldwide. The global cumulative capacity is expected to reach 11,800 MW by year-end 2015. A review of project announcements suggests that cumulative global offshore wind capacity could grow to more than $47,000 \mathrm{MW}$ by 2020. Although the majority of this capacity is being built in Europe, the industry is becoming more geographically dispersed with projects now under construction in the Asian and U.S. markets.

\section{Deepwater Wind Begins Installation of First U.S. Offshore Wind Project}

The 30-MW Block Island Wind Farm (BIWF) project started offshore construction in 2015 and is likely to be the nation's first offshore commercial wind project. Deepwater Wind reached financial close for the BIWF in March 2015, with a \$290 million debt financing package. Marine contractors began installing five conventional four-legged jacket substructures in the summer of 2015. Five 6-MW direct-drive Alstom Haliade turbines will be installed on these foundations in spring and summer 2016, as well as the 34.5-kilovolt cable that will connect Block Island to the mainland. Besides being the first U.S. commercial offshore wind project, the BIWF promises to significantly lower electricity prices for the residents of Block Island and provide substantial clean energy to the mainland townships of southern Rhode Island. The project is expected to generate up to 300 jobs during construction. 


\section{5,650 MW of U.S. Projects are in Various Stages of Development}

As of June 20, 2015, there are 21 U.S. offshore wind projects in the development pipeline, representing 15,650 MW of offshore wind. Out of these projects, 13 projects, representing 5,939 MW, have achieved site control or a more advanced phase of development. Approximately 3,305 MW of U.S. projects have announced a commercial operation date by 2020 , consistent with the timing of the deployment scenario laid out in the U.S. Department of Energy's (DOE's) Wind Vision. Beyond 2020, the Wind Vision scenario includes the deployment of 22,000 MW by 2030 and $86,000 \mathrm{MW}$ by 2050 ; with future deployment occurring in all major coastal regions.

\section{U.S. Bureau of Ocean Energy Management Issued Offshore Wind Leases that Could Support an Estimated 5,768 MW of Offshore Wind Projects in Federal Waters}

To date, the Bureau of Ocean Energy Management (BOEM) has issued two leases on a noncompetitive basis and conducted four competitive auctions for wind energy areas along the Atlantic Coast. In August 2014, BOEM announced that U.S. Wind, Inc. was the winning bidder for two lease areas delineated offshore Maryland, and, in January 2015, announced that Renewable Energy Systems Americas and OffshoreMW had each won one lease area offshore Massachusetts. Renewable Energy Systems Americas later transferred its lease to DONG Energy, the worldwide leader in offshore wind development, which imbued the sector with fresh confidence. BOEM has now awarded offshore leases with a total value of $\$ 14.5$ million under the "Smart from the Start" program. As the leasing process continues, BOEM has identified wind energy areas in New Jersey and North Carolina totaling nearly 9,000 MW of additional potential capacity that has not yet been auctioned.

\section{Advanced Technology Demonstration Projects Make Progress but Pace is Slower than Expected}

As part of its National Offshore Wind Strategy launched in February 2011, DOE created a new initiative to provide support for regionally diverse Offshore Wind Advanced Technology Demonstration (ATD) Projects through collaborative public/private partnerships. The primary goal of the ATD projects is to demonstrate innovative offshore wind systems in U.S. waters in a rapid and responsible manner that have the potential to lower the levelized cost of energy (LCOE). In addition, the program seeks to establish test capabilities, validate infrastructure, exercise the state and federal regulatory processes relevant to offshore wind, and address investor risk perceptions. DOE selected three projects in May 2014 to advance to the second phase of the ATD program: Dominion Power's Virginia Offshore Wind Technology Advancement Project, Fishermen's Atlantic City Windfarm, and Principle Power's WindFloat Pacific. Each project is eligible to receive up to $\$ 47$ million to complete final design, fabrication, deployment, and demonstration, and all projects are targeted to achieve commercial operation by the end of 2017; however, recent events suggest that the projects may need more time to work through the development process than originally anticipated. 


\section{Trends Indicate Technology Advances and Supply Chain Maturity May Be Helping the Industry to Reverse Cost Increases}

This report presents analysis that illustrates how global projects are being sited in areas that are located in deeper water and farther from shore. These characteristics impose new technical requirements for offshore wind projects and have contributed to the increase in capital expenditures observed from 2005 to 2014. Future cost projections, however, suggest that technology innovation and a maturing supply chain could drive a decline in LCOE through 2020. Some policymakers in the European Union are amplifying the impacts of technology innovation by designing policies that reduce risk for developers, lower the prices required to make projects financially viable, and minimize costs to ratepayers.

\section{Recent Evidence Suggests Offshore Wind is on Track to Meet 2020 Industry Targets for LCOE Reduction}

The European industry and stakeholders have set a target of reducing the LCOE for offshore wind projects by $40 \%$ for projects that close financing in 2020, relative to 2010 levels. As a result, the United Kingdom government set up the Cost Reduction Monitoring Framework to track the industry's progress towards cost reduction. The first Cost Reduction Monitoring Framework report, which was released in 2015, found that the average LCOE for projects that closed financing between 2012 and 2014 declined by 11\% relative 2010 levels. Also in 2015, the United Kingdom and Denmark held competitive auctions for price support, which resulted in the lowest power prices for offshore wind in recent history. The winning bids for the two projects in the United Kingdom, which are expected to close financing in 2016/2017, were $29 \%$ to $32 \%$ below 2010 levels. The competitive tender in Denmark showed similar results, with the winning bid coming in 32\% lower than the previous auction, which was conducted in 2010 . These results show that the industry is well in advance of the trajectory required to reach its 2020 cost reduction goals.

\section{The United States is Positioned to Leverage European Technologies and Experience that are Driving Cost Reduction}

The progress towards cost reduction in the European offshore wind energy industry should translate to U.S. projects and allow developers to offer offshore wind power at increasingly competitive prices relative to other low-carbon sources of electricity generation. The BIWF and ATD projects are expected to enable the U.S. industry to gain valuable experience by using the best-available European technology, as well as other project-specific innovations to adapt the technology to U.S. siting challenges. These projects are expected to help streamline and de-risk offshore wind investment in the United States by exercising the permitting process, generating information about U.S. operating conditions, and showcasing the capabilities of the U.S. supply chain. The two main challenges for the industry are 1) the limited viable revenue mechanisms that could support commercial projects in the near term and 2) the lack of long-term market visibility necessary to foster and sustain the development of a domestic offshore wind supply chain. 


\section{Table of Contents}

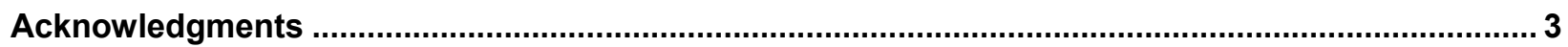

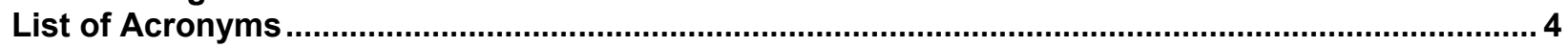

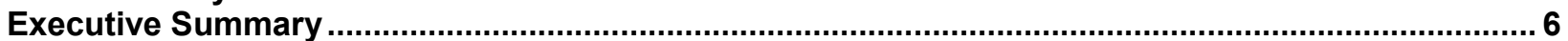

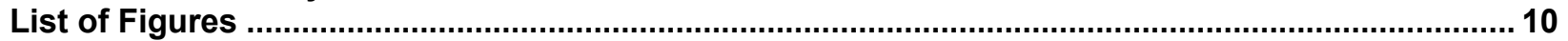

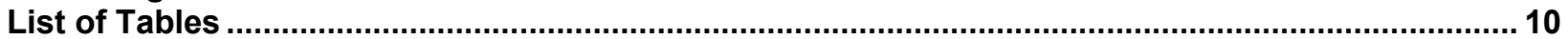

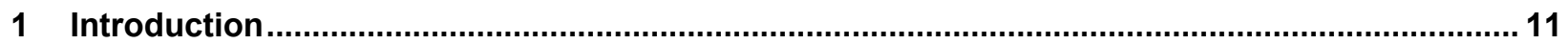

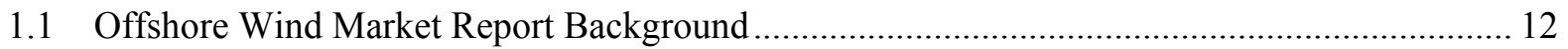

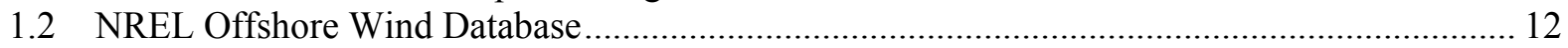

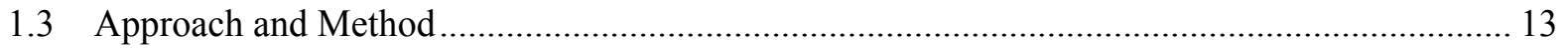

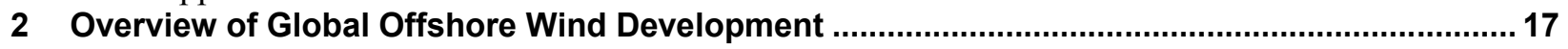

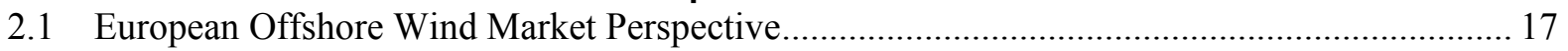

2.2 Asian Offshore Wind Market Developments ........................................................................ 19

2.3 Global Offshore Wind Market (Annual and Cumulative) ..................................................... 20

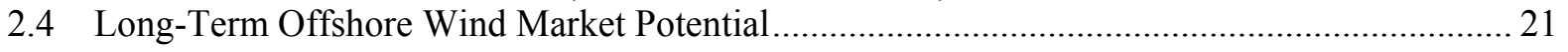

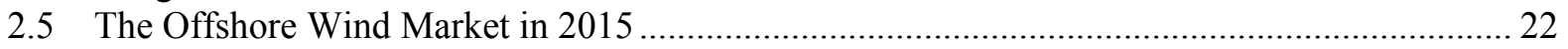

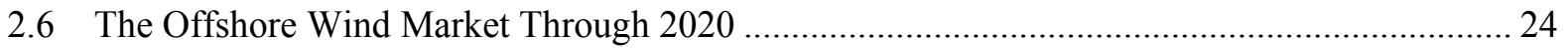

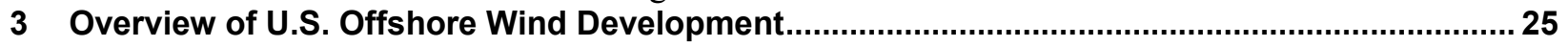

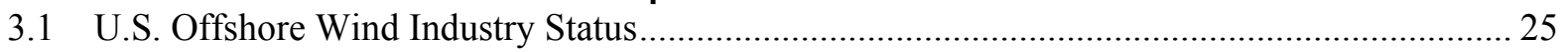

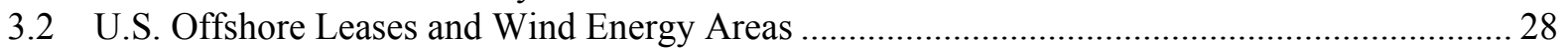

3.3 U.S. Offshore Wind Project Development Pipeline .................................................................. 33

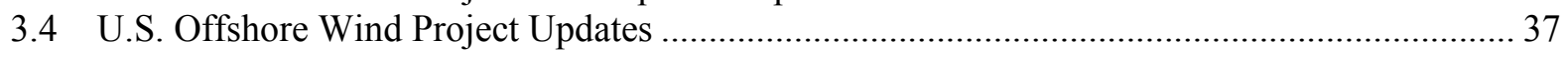

3.5 U.S. Advanced Technology Demonstrations Projects ...................................................... 41

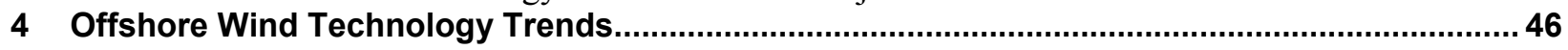

4.1 Site Characteristics for Global Offshore Wind Projects..................................................... 46

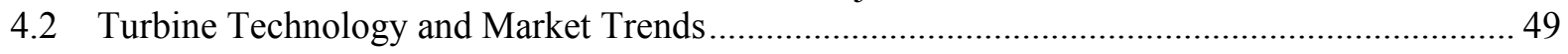

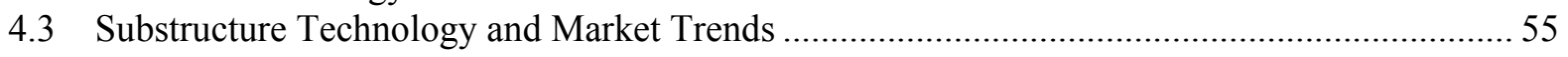

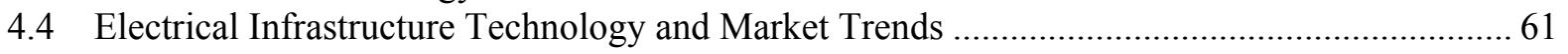

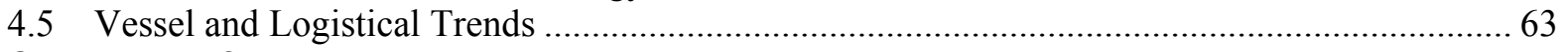

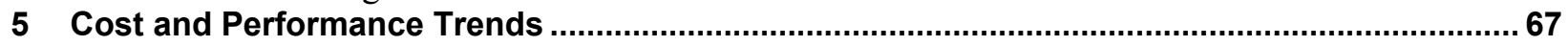

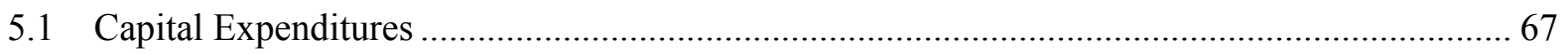

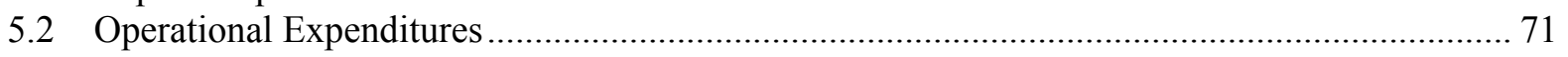

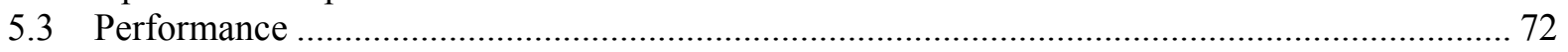

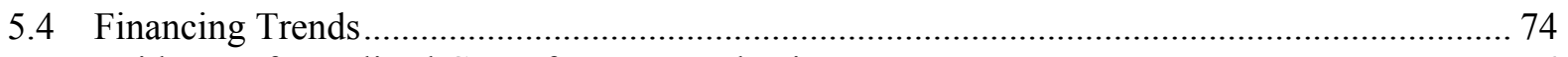

5.5 Evidence of Levelized Cost of Energy Reduction ............................................................ 76

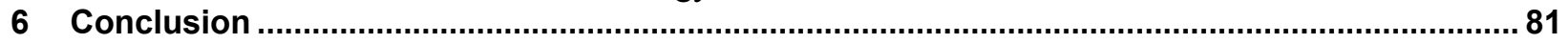

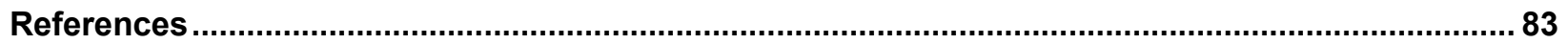

Appendix A. U.S. Offshore Wind Projects: Under Construction and Approved ............................... 98

Appendix B. U.S. Offshore Wind Projects: Major Permits Submitted .............................................. 100

Appendix C. U.S. Offshore Wind Projects: Planning with Site Control....................................... 102

Appendix D. U.S. Offshore Wind Projects: Early-Stage Planning (Without Site Control) ................ 104

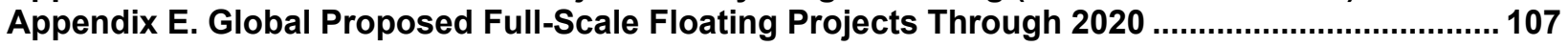

Appendix F. Revenue Analysis for Recent European Subsidy Auctions ..................................... 110 


\section{List of Figures}

Figure 1. Operating global offshore wind capacity (annual and cumulative)....................................21

Figure 2. Operating and development pipeline for offshore wind projects by region..................... 22

Figure 3. Comparison of national market share for operating versus under construction projects 23

Figure 4. Global offshore wind project pipeline through 2020 (by country) ................................... 24

Figure 5. Current U.S. federal offshore wind leases, WEAs, and call areas on the Atlantic OCS.... 32

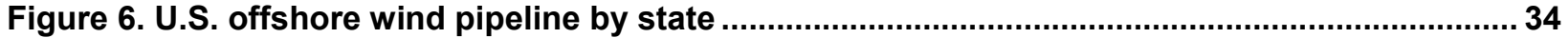

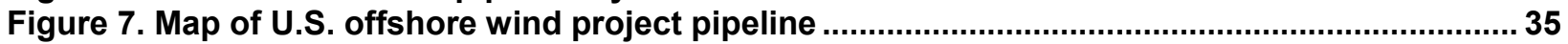

Figure 8. U.S. offshore wind project pipeline by state and development status............................... 36

Figure 9. The 30-megawatt Block Island Wind Farm under construction ....................................... 38

Figure 10. Advanced Technology Demonstration Project awardees .............................................41

Figure 11. Projects selected to continue technology advancement ............................................ 44

Figure 12. Global offshore wind projects as a function of water depth and distance to shore........ 47

Figure 13. Global turbine capacities, rotor diameters, and hub heights over time..........................50

Figure 14. Wind turbine prototype capacity and drivetrain architectures ...................................... 52

Figure 15. Global market for offshore wind turbine OEMs ............................................................ 54

Figure 16. Offshore wind substructure designs for varying water depths .........................................55

Figure 17. Global offshore wind substructure market share ............................................................5 56

Figure 18. Recent foundation supply contracts showing anticipated foundation types by water

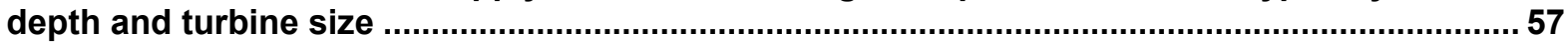

Figure 19. Global pipeline of operating and proposed floating offshore wind projects ..................60

Figure 20. Global offshore wind projects weighted average capital expenditures by commercial operation date.

Figure 21. CapEx trends for offshore wind projects by country....................................................... 70

Figure 22. Net capacity factor for selected European offshore wind projects (by country) ..............73

Figure 23. European LCOE estimated from empirical surveys and subsidy auction results ........... 80

Figure F-1. Horns Rev III revenue analysis................................................................................. 110

Figure F-2. Neart Na Gaoithe revenue analysis ...................................................................... 111

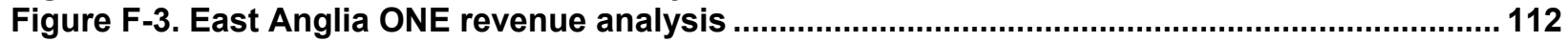

\section{List of Tables}

Table 1. Summary of Criteria for Reporting on Offshore Wind Project Status................................. 15

Table 2. Summary of Operating and Under Construction Offshore Wind Projects by Country ....... 23

Table 3. Summary of Awarded Commercial Offshore Leases and Wind Energy Areas ..................... 30

Table 4. Summary of Site Characteristics by Project Status.......................................................... 47

Table 5. Turbine Supply Agreement Costs........................................................................................ 71

Table 6. Summary of Lifetime Revenue for Horns Rev III, Neart Na Gaoithe, and East Anglia ONE 78

Table A-1. U.S. Offshore Wind Projects Currently Under Construction or Approved ....................... 98

Table B-1. U.S. Offshore Wind Projects That Have Submitted Major Permits................................. 100

Table C-1. U.S. Offshore Wind Projects in the Planning - Site Control Phase..................................102

Table D-1. U.S. Offshore Wind Projects in the Early-Stage (Without Site Control) Phase .............. 104

Table E-1. Proposed Full-Scale Floating Projects Worldwide (Through 2020).............................. 107 


\section{Introduction}

For the U.S. offshore wind market, 2015 has been an exciting, yet tumultuous, year. A number of promising projects have run into economic, legal, and political headwinds, generating much speculation about the future of the industry. But, after more than 15 years of development work, the United States has finally hit a crucial milestone: Deepwater Wind began offshore construction on the 30-megawatt (MW) Block Island Wind Farm (BIWF) in July 2015-making it the nation's first offshore wind project.

The slow start to the U.S offshore industry and the current market uncertainties are not without precedent; each major market for offshore wind began with pilot-scale, proof-of-concept projects before eventually moving to larger, commercial-scale installations. Now, after more than a decade of commercial experience, the global industry, which has installed 8,990 MW, is set to achieve a new deployment record of 3,996 MW in 2015 and is making demonstrable progress towards industry-wide goals for cost reduction.

Deepwater Wind is leveraging 25 years of European technical experience, as well as U.S. fabrication and installation competencies, to construct the first project. The successful deployment of the BIWF will provide a showcase that can illustrate offshore wind's potential to contribute to state, regional, and national goals for clean, reliable power. The U.S. industry and its stakeholders anticipate that this initial project, as well as recent state and federal policy developments, could launch the U.S. industry into a phase of commercial development that will position offshore wind to contribute significantly to the electric systems in coastal states by 2030 (Del Franco 2015a).

This report was developed by the National Renewable Energy Laboratory (NREL) and is intended to provide stakeholders, including policymakers, regulators, developers, financiers, and supply chain participants, with quantitative information about the offshore wind market, technology, and cost trends worldwide. The data presented in this report are intended to provide context for the domestic industry and help the U.S. offshore wind industry and its stakeholders identify barriers and opportunities. The scope of the report covers the fleet of operating projects through June 30, 2015, ${ }^{1}$ with particular focus on developments in 2014 and the first half of 2015, to provide historical context and summarize current status. It also includes available data about projects that are currently under development to provide a forward-looking perspective.

The remainder of the report is divided into five main sections that focus on the following:

- Section 2 provides an overview of the global offshore wind market

- Section 3 summarizes offshore wind market developments in the United States

- Section 4 analyzes global and domestic offshore wind technology trends

- Section 5 provides insight into offshore wind cost and performance trends

- Section 6 summarizes key findings.

\footnotetext{
${ }^{1}$ This report also refers to the June 30, 2015, date as "Q2 2015" in text and figures.
} 


\subsection{Offshore Wind Market Report Background}

The U.S. Department of Energy (DOE) Office of Energy Efficiency and Renewable Energy funds market reports for various wind technologies, including utility-scale land-based wind, ${ }^{2}$ offshore wind, and distributed wind. ${ }^{3}$ These companion reports provide quantitative, independent data for use by the wind industry and its various stakeholders.

DOE has sponsored a market report for offshore wind technologies since 2012. A consortium led by Navigant Consulting published reports in 2012, 2013, and 2014 under a contract award through Funding Opportunity Announcement 414 (see Hamilton et al. 2013a, 2013b, and 2014). The Navigant-led reports covered a broad scope, including global offshore wind development trends, policy development analysis, offshore wind economic impacts, as well as progress in relevant sectors of the economy.

This 2014 market report is intended to be a scaled-back version of the Navigant market reports and covers offshore wind market and technology trends, which can vary considerably on an annual basis. These data provide insight into market, technology, cost, and performance trends and are key inputs to the annual Cost of Wind Energy Review report, which provides an annually updated summary of the cost of land-based and offshore wind energy in the United States to support DOE's programmatic reporting (Tegen et al. 2012, Tegen et al. 2013, Moné et al. 2015).

\subsection{NREL Offshore Wind Database}

This report draws on NREL's Offshore Wind Database (OWDB), which contains information on 1,382 offshore wind projects located in 40 countries and totaling about 730,000 MW of announced project capacity (including both active and dormant projects). Projects in the database range in maturity and cover a time period from 1991 to 2034, although many have not yet announced a commercial operation date (COD). The OWDB contains information on project characteristics (e.g., water depth, wind speed, and distance from shore), economic attributes (e.g., project- and component-level costs and performance), and technical specifications (e.g., component sizes and masses). Additionally, the database contains information on the characteristics of offshore wind installation and transportation vessels, as well as ports that have been used to support the construction and maintenance of offshore projects.

The OWDB draws on various resources including peer-reviewed literature, press releases, industry news reports, manufacturer specification sheets, and global offshore wind project announcements. In cases where these sources conflict with each other or with other sources available to NREL, the data were adjusted to reflect best available information. Typically, the augmented data are sourced from industry experts and/or NREL analysis. To ensure accuracy, NREL has validated stored data against other databases, publications from institutions and associations, and research organizations, including:

\footnotetext{
${ }^{2}$ The Wind Technologies Market Report is prepared by Lawrence Berkeley National Laboratory and is available for the period 2005 to 2014. For the most recent version see Wiser and Bollinger (2015).

${ }^{3}$ The Distributed Wind Market Report is prepared by Pacific Northwest National Laboratory for the period 2012 to 2014. For the most recent version, see Orrell and Foster (2015).
} 
- The 4C Offshore Wind Database (4C Offshore 2015)

- European Wind Energy Association (EWEA) Annual Market Update (EWEA 2015)

- Navigant World Wind Energy Market Update (Broehl et al. 2015).

Although best attempts were made to validate the data and harmonize it against other available sources, the minor differences in database methodology among sources may naturally yield slightly different results than found in other published reports. For example, reported annual capacity additions often vary among sources because of the use of different criteria for considering a project as "operating" or "installed." Despite variability in annual numbers, longerterm trends are broadly consistent. NREL considers a project to be commissioned when all turbines are fully operational and capable of feeding power into the land-based electricity grid.

The data also vary in quality and, in many cases, are subject to some uncertainty. This is particularly true for future projects, in which values are largely based on the public announcements of developers and may be subject to change. Because of these uncertainties, the analysis presented here emphasizes the broader trends rather than data points corresponding to individual projects.

\subsection{Approach and Method}

The analysis contained in this report focuses on offshore wind projects at various stages of maturity within the project life cycle, starting with the first deployment in 1991 and extending into the future. It also covers projects in a range of countries, spanning North American, European, and Asian markets; however, it is often difficult to compare between markets because of differences in political systems, regulatory conditions, and the macroeconomic climate.

The breadth and diversity of the data set requires the development of consistent methodologies to classify and analyze the data. The Navigant annual market reports tracked U.S. projects that had reached an "advanced stage" of development as a way of reporting on industry growth and progress. Hamilton et al. (2013a, 2013b, and 2014) defined "advanced-stage" projects as those that have accomplished at least one of the following three milestones:

- Received approval for an interim limited lease or a commercial lease in state or federal waters

- Conducted baseline or geophysical studies at the proposed site with a meteorological tower erected and collecting data, boreholes drilled, or a geological and geophysical data acquisition system in use

- Signed a power purchase agreement (PPA) with a power off-taker.

Each of the criteria was identified as a requisite step that a project would have to complete before it could reach a final investment decision (FID) that would enable construction to start. Simply having achieved one of these milestones, however, did not guarantee that a project would move forward, and any two projects qualifying as "advanced" may have made different levels of progress relative to one another. Under these criteria, projects or wind energy lease areas that were not considered "advanced" did not get acknowledged. Similarly, projects that had met more than one or all of the criteria were not distinguished from each other. Therefore, on an annual basis, it was difficult to see significant progress or setbacks because projects would not change 
status even when important changes occurred. It was also difficult to compare the advanced projects in the United States to international projects because the criteria did not directly translate across borders.

\subsubsection{Classification of Project Status}

For this report, NREL developed a new system for classifying and tracking the progress of projects within the global offshore wind development pipeline. One of the main objectives for this new framework was to generalize the classification system to make it applicable across multiple markets and regulatory regimes, including projects that are proposed in both federal waters and state waters in the United States, as well as those operating and proposed in other countries. It was also important that the classification system defined discrete start- and endpoints for each life cycle phase to avoid overlap or ambiguity. The purpose of the new criteria is to provide an objective way of assessing project status based on measurable milestones, rather than requiring subjective assessments or unsubstantiated forecasts of project likelihood.

The new classification system divides the offshore wind project life cycle into nine stages: 1) planning - early stage, 2) planning - site control, 3) major permits submitted, 4) approved, 5) financial close, 6) under construction, 7) operating, 8) decommissioned, and 9) on hold/canceled. ${ }^{4}$ These stages ensure that every potential project is acknowledged and can be tracked throughout the project life cycle.

Table 1 summarizes the start and end criteria for the nine project phases and provides examples of some of the key milestones that exist within the U.S. regulatory framework. These criteria are broadly generalizable across all international markets for offshore wind (see, for example, 4C Offshore 2015); however, criteria are not likely to be perfectly applicable to every market, particularly in project phases 1 through 5 , in which political and regulatory structures impose different requirements. These different requirements will likely translate into variability in the duration and financial resources required to progress from one stage to the next.

\footnotetext{
${ }^{4}$ Note that the OWDB does not differentiate between the first category (planning - early stage) and the second (planning - site control) for international projects. Instead, both are tracked as a single, combined category labeled "Planning."
} 
Table 1. Summary of Criteria for Reporting on Offshore Wind Project Status

\begin{tabular}{|c|c|c|c|}
\hline Step & Phase Name & Phase Start Criteria & Phase End Criteria \\
\hline 1 & $\begin{array}{l}\text { Planning - Early } \\
\text { Stage }\end{array}$ & $\begin{array}{l}\text { Starts when developer or regulatory agency } \\
\text { initiates formal site control process }\end{array}$ & $\begin{array}{l}\text { Ends when a developer obtains exclusive } \\
\text { development rights to a site (e.g., through } \\
\text { competitive auction or a determination of no } \\
\text { competitive interest in the United States) }\end{array}$ \\
\hline 2 & $\begin{array}{l}\text { Planning - Site } \\
\text { Control }\end{array}$ & $\begin{array}{l}\text { Begins when the developer obtains exclusive } \\
\text { development rights to a site (e.g., through } \\
\text { competitive auction or a determination of no } \\
\text { competitive interest in the United States) }\end{array}$ & $\begin{array}{l}\text { Ends when the developer files major permit } \\
\text { applications (e.g., a construction operations } \\
\text { plan for projects in federal waters in the } \\
\text { United States) }\end{array}$ \\
\hline 3 & $\begin{array}{l}\text { Major Permits } \\
\text { Submitted }\end{array}$ & $\begin{array}{l}\text { Starts when the developer files major permit } \\
\text { applications (e.g., construction operation plan } \\
\text { for projects in federal waters in the United } \\
\text { States) }\end{array}$ & $\begin{array}{l}\text { Ends when a regulatory body(s) grants } \\
\text { authorization to proceed with construction; a } \\
\text { rejection may cause the project sponsor to } \\
\text { appeal (still permitting phase), place the } \\
\text { project on hold, or cancel }\end{array}$ \\
\hline 4 & Approved & $\begin{array}{l}\text { Starts when project has been approved by the } \\
\text { relevant regulatory bodies and is fully } \\
\text { authorized to proceed with construction }\end{array}$ & $\begin{array}{l}\text { Ends when sponsor announces FID, and has } \\
\text { signed unconditional contracts for major } \\
\text { construction work packages; achievement of } \\
\text { this milestone generally requires that a project } \\
\text { has secured sufficient revenue mechanisms } \\
\text { (e.g., power offtake contracts, subsidies, or } \\
\text { tax incentives) to be financially viable }\end{array}$ \\
\hline 5 & Financial Close & $\begin{array}{l}\text { Begins when sponsor announces FID and has } \\
\text { signed unconditional contracts for major } \\
\text { construction work packages; achievement of } \\
\text { this milestone generally requires that a project } \\
\text { has secured sufficient revenue mechanisms } \\
\text { (e.g., power offtake contracts, subsidy, or tax } \\
\text { incentives) to be financially viable }\end{array}$ & $\begin{array}{l}\text { Ends when project begins offshore } \\
\text { construction work }\end{array}$ \\
\hline 6 & $\begin{array}{l}\text { Under } \\
\text { Construction }\end{array}$ & $\begin{array}{l}\text { Starts when offshore construction work is } \\
\text { initiated }\end{array}$ & $\begin{array}{l}\text { Ends when project has been connected to the } \\
\text { power grid and all units fully commissioned; } \\
\text { COD marks the official hand-over from } \\
\text { construction to operations }\end{array}$ \\
\hline 7 & Operating & $\begin{array}{l}\text { Commences when project has been } \\
\text { connected to the power grid and all units fully } \\
\text { commissioned; COD marks the official hand- } \\
\text { over from construction to operations }\end{array}$ & $\begin{array}{l}\text { Ends when the project has begun a formal } \\
\text { process to decommission and stops feeding } \\
\text { power to the grid }\end{array}$ \\
\hline 8 & Decommissioned & $\begin{array}{l}\text { Starts when the project has begun a formal } \\
\text { process to decommission and stops feeding } \\
\text { power to the grid }\end{array}$ & $\begin{array}{l}\text { Ends when the site has been restored and } \\
\text { lease payments are no longer being made, or } \\
\text { if the site has been repowered }\end{array}$ \\
\hline N/A & $\begin{array}{l}\text { On Hold/ } \\
\text { Canceled }\end{array}$ & $\begin{array}{l}\text { Starts when sponsor stops development } \\
\text { activities (i.e., discontinues lease payments) } \\
\text { and/or abandons a prospective site }\end{array}$ & $\begin{array}{l}\text { Ends when the sponsor announces the restart } \\
\text { of project development activities }\end{array}$ \\
\hline
\end{tabular}

Acronyms used in table: Commercial operation date (COD); final investment decision (FID) 


\subsubsection{Normalization of Cost and Price Data}

The cost and pricing data in NREL's OWDB spans a large chronology and is reported in a number of different currencies. To analyze these data, all information in this report was normalized into 2014 U.S. dollars (USD) by:

- Converting costs and prices to USD using the exchange rate for the year in which the latest data were reported (United States Department of Agriculture 2015)

- Inflating the values, which are in nominal USD after the exchange rate conversion, to 2014 USD using the U.S. Consumer Price Index (BLS 2015).

Because this report focuses on the data from 2014 to June 30, 2015, NREL used the 2014 average exchange rates to convert other economic data not directly tied to projects (e.g., from studies or related to policy). This means that the recent appreciation of the dollar against the euro and other currencies is not fully captured in this report. 


\section{Overview of Global Offshore Wind Development}

The global market for offshore wind energy is rooted in Europe but market trends indicate a shift toward an increasingly wider global distribution of development in the coming years. Global market trends are based largely upon European experience and data show positive market indicators for technology innovation, policy advancement, and cost reduction. Present and future deployment is tracked according to industry reports, and is summarized for operating projects as well as projects that are in the development pipeline for the period ending in June 2015. Major trends are then determined by making comparisons between operating projects and projects in the development pipeline according to country, actual or announced COD, and progress within the regulatory process. Stakeholders can use these insights to better anticipate future market developments and establish long-term commercial plans as well as technology research and development $(\mathrm{R} \& \mathrm{D})$ strategies.

\subsection{European Offshore Wind Market Perspective}

The European offshore wind industry is more than 20 years old and its technical practices and market data are the cornerstone for assessing market potential and trends worldwide. These data informed our assessments of the budding Asian offshore wind market and are essential for understanding and benchmarking cost and technology trends in the emerging U.S. offshore wind market. The European offshore wind industry, including its policymakers, regulators, and R\&D funding bodies, continues to take coordinated action to achieve offshore wind deployment and cost reduction targets. As a result, these concerted actions have led to a strong downward trend in expected power generation prices for offshore wind in the coming years as evidenced by recent competitive subsidy auction results in Denmark and the United Kingdom (see Section 5.5).

Cost reduction within the European market is being driven by the industry's aggressive development of new technology and corresponding commitments by developers to adopt it into offshore wind projects. This new technology development is encouraged by a stable deployment outlook, averaging 4,000 MW per year from 2015 to 2020 that provides the market visibility required to sustain an efficient supply chain. The volume associated with this pipeline has several benefits for the industry that can reduce costs, including increasing economies of scale, improving infrastructure and manufacturing facilities, increasing competition within the supply chain, and fostering a skilled workforce.

Based on announced commercial orders, the market has recently seen a clear jump to technology platforms with turbine nameplate ratings between 6 and $8 \mathrm{MW}$. This new generation of offshore turbines is expected to embody the best available technology as measured by cost, reliability, and performance. A driving mechanism of this influx of larger machines is the confidence that some European utilities have in the market and the willingness to assume some technology risk. Utilities, primarily led by DONG Energy, have placed orders for new turbines before being fully certified, thus providing the original equipment manufacturers (OEMs) with the market certainty they need to commercialize new products and build efficient supply chains. Innovations in foundation design, installation techniques, and electrical infrastructure are also being demonstrated and adopted in near-term commercial projects in Europe. The industry has also benefited from some positive macroeconomic trends, such as stable commodity prices, reduced oil and gas development activity, and favorable exchange rates, which have contributed to lower cost levels. 
Furthermore, some European policymakers have developed support schemes and regulatory policies that are designed to minimize project cost and reduce the price impacts on ratepayers.

Some examples of these programs include:

- Selecting development zones that emphasize site affordability. The Danish government recently held a tender for up to $350 \mathrm{MW}$ of nearshore projects, which are anticipated to have low cost levels resulting from their proximity to the shore (ranging from 4 to 8 kilometers $(\mathrm{km})$ (Weston 2015a). These zones may, however, have lower wind speeds and therefore reduced capacity factors - relative to open-ocean sites — which makes it difficult to predict the likely levelized cost of energy (LCOE).

- Sponsoring early-stage development activities to reduce uncertainty about site conditions. Denmark, the Netherlands, and Belgium are defining development zones and conducting initial environmental assessments, geotechnical surveys, wind resource assessments, and meteorological (met) ocean condition studies before holding auctions for development rights. These auctions provide prospective developers with knowledge that allows them to estimate cost and performance of a site with increased confidence, reducing risk and enabling auctions to be based more on price competitiveness than on a given developer's willingness to accept risk (McClellan 2015).

- Implementing competitive auctions for subsidies. Denmark, the United Kingdom, and the Netherlands are adopting market mechanisms to price subsidies based on competitive auctions. The use of market mechanisms to discover price is based on the idea that competition will drive developers to offer their best price, rather than a price set by a government agency that often does not have insight into the cost structure for individual projects. ${ }^{5}$ These competitive auctions for price subsidy are sometimes combined with auctions for development rights (Milborrow 2015). The trend towards market mechanisms for awarding subsidies is expected to expand in the future, driven by the European Union's emphasis on competition as expressed in its revised Guidelines on State aid for environmental protection and energy 2014-2020 (European Commission 2014).

Despite these positive developments, the industry has expressed concern regarding current political uncertainty on future deployment levels for offshore wind within national energy plans, particularly after 2020 . Governments have largely not defined the subsidy levels that will be available to the industry after this timeframe or the role of offshore wind in national renewable energy deployment targets. The industry maintains that clarity about the future pipeline is needed to drive supply chain investments in new technologies and efficient infrastructure (Campbell 2015; Steiner-Dicks 2015). Uncertainty about future market size may be a barrier to further cost reduction (Offshore Renewable Energy [ORE] Catapult 2015).

\footnotetext{
${ }^{5}$ It is challenging for government agencies to set price support levels because they must balance between a level that is high enough to attract development but low enough that the developer does not earn returns that are excessively high. Moreover, cost levels are often set on a national level and must be appropriate for a variety of projects with diverse site conditions and, therefore, generating costs.
} 


\subsection{Asian Offshore Wind Market Developments}

Several Asian markets, including China, Japan, Taiwan, and South Korea are taking steps to stimulate domestic offshore wind industries and accelerate deployment. Developments in these markets could have implications for the U.S. industry. Future Asian supply chains could provide a counterweight to European suppliers and increase competition within the industry, which could reduce cost levels. Further, site conditions in many Asian markets are different than those in Europe. Many potential development zones are located in sites characterized by deep water and exposure to typhoons. Early experience gained through deploying and operating offshore wind projects in these conditions could be relevant for certain regions of the United States. Similarly, Asian markets offer an opportunity for exports, such as floating platform technologies that are under development by U.S. companies.

China is currently the leading market for offshore wind power in Asia, with several projects installed. Yet, deployment has been much slower than the government originally anticipated because of a fragmented permitting process and feed-in tariff rates that are insufficient to make projects economically viable. The National Energy Agency in China recently revealed that it would reduce deployment targets in the $13^{\text {th }} 5$-year plan; from $30,000 \mathrm{MW}$ by 2020 down to $10,000 \mathrm{MW}$ (Jianxiang 2015). Despite reductions in the speed of deployment, a number of offshore wind projects have received approval from the government to proceed with construction and nearly 10 turbine manufacturers are developing machines to support the eventual build-out.

As a direct result of the Fukushima nuclear power plant meltdown resulting from the earthquake and tsunami in March 2011, the Japanese government shifted the focus of its energy policy away from nuclear power; approximately 50 reactors currently sit idle and imports of liquefied natural gas, crude oil, coal, and petroleum products have risen to fill in the gap. ${ }^{6}$ Japan's Ministry of Economy, Trade and Industry (METI) released a draft plan in 2015 that calls for nuclear energy to account for $22 \%$ of future power generation, although public opposition remains strong. As part of their new energy strategy, the government has committed to actively developing offshore wind energy, one of Japan's only domestic energy resources. The waters off the Japanese coastline are deep, however, and the typical fixed-bottom technology developed for North Sea applications is economically unsuitable in most locations.

To meet these challenges, Japan is funding the rapid development and deployment of floating offshore wind technology. Since 2013, Japan has deployed three floating wind turbines, including a 7-MW turbine in summer 2015, which is now the largest floating offshore wind turbine in the world. Japan has deployed the most floating offshore wind capacity of any country to date and hopes to leverage its strong marine and shipbuilding competencies to expand upon this initial experience. The government has enacted a feed-in tariff for offshore wind that will deliver 36,000 yen/megawatt-hour $(\mathrm{MWh})(\$ 350 / \mathrm{MWh})$ for 20 years and expects that this subsidy will increase commercial interest in building offshore wind farms that would contribute to the country's goal of obtaining $20 \%$ of its electricity needs from wind power by 2050 (Grandum and Ishihara 2015).

\footnotetext{
${ }^{6}$ In 2015, Japan restarted the first nuclear reactor since 2012; the government plans to restart more reactors under new safety standards to reduce liquefied natural gas imports and electricity costs (Sheldrick and Kato 2015).
} 
South Korea installed its first offshore wind turbines in 2012, following a 2011 announcement that the government would provide nearly $\$ 8$ billion to fund the phased development of a 2,500MW offshore project, with operations beginning in 2019. Although development appears to be lagging, as a result of concerns raised by the fishing industry, approximately $500 \mathrm{MW}$ of projects are advancing through the Korean pipeline. Korea hopes to build capabilities that leverage its shipyards and heavy industry and is designing policies to foster the development of wind turbines from domestic suppliers (Korea Environmental Industry \& Technology Institute 2013).

Taiwan is also emerging as a potentially large offshore wind market. The government has announced targets of deploying $600 \mathrm{MW}$ of capacity by 2020 and 4,000 MW by 2030. To enable the industry to reach these targets, the government is taking a phased approach that will see the deployment of several small demonstration projects that are scheduled to begin operations in 2016. These small projects will be followed by three $200-\mathrm{MW}$ demonstration projects scheduled to begin operation in 2020. Finally, the government plans to designate commercial development zones in the post-2020 timeframe (Hu 2012; Weston 2015b).

Finally, India is an additional potential market for offshore wind in Asia. Even though the government has yet to announce deployment goals or incentives, state governments, including Gujarat and Tamil Nadu, are reportedly planning pilot projects that could be online by 2019 (Windpower Monthly 2015).

\subsection{Global Offshore Wind Market (Annual and Cumulative)}

Figure 1 shows the global cumulative and annual offshore wind installed capacity from 2000 through June 2015. These data only include projects that were fully commissioned (i.e., the entire wind plant is feeding power into the grid), and are based on project-announced commission dates from publicly available data sources. Note that the figure only includes projects in which all of the capacity has been fully commissioned in a given year and does not include intertidal projects. ${ }^{7}$

\footnotetext{
${ }^{7}$ Europe and the United States are not expected to install intertidal projects, which are located on beaches or tidal plains, because of environmental and competing use concerns. Intertidal projects have limited relevance because they use different foundational technologies, installation methods, and electric infrastructure designs.
} 


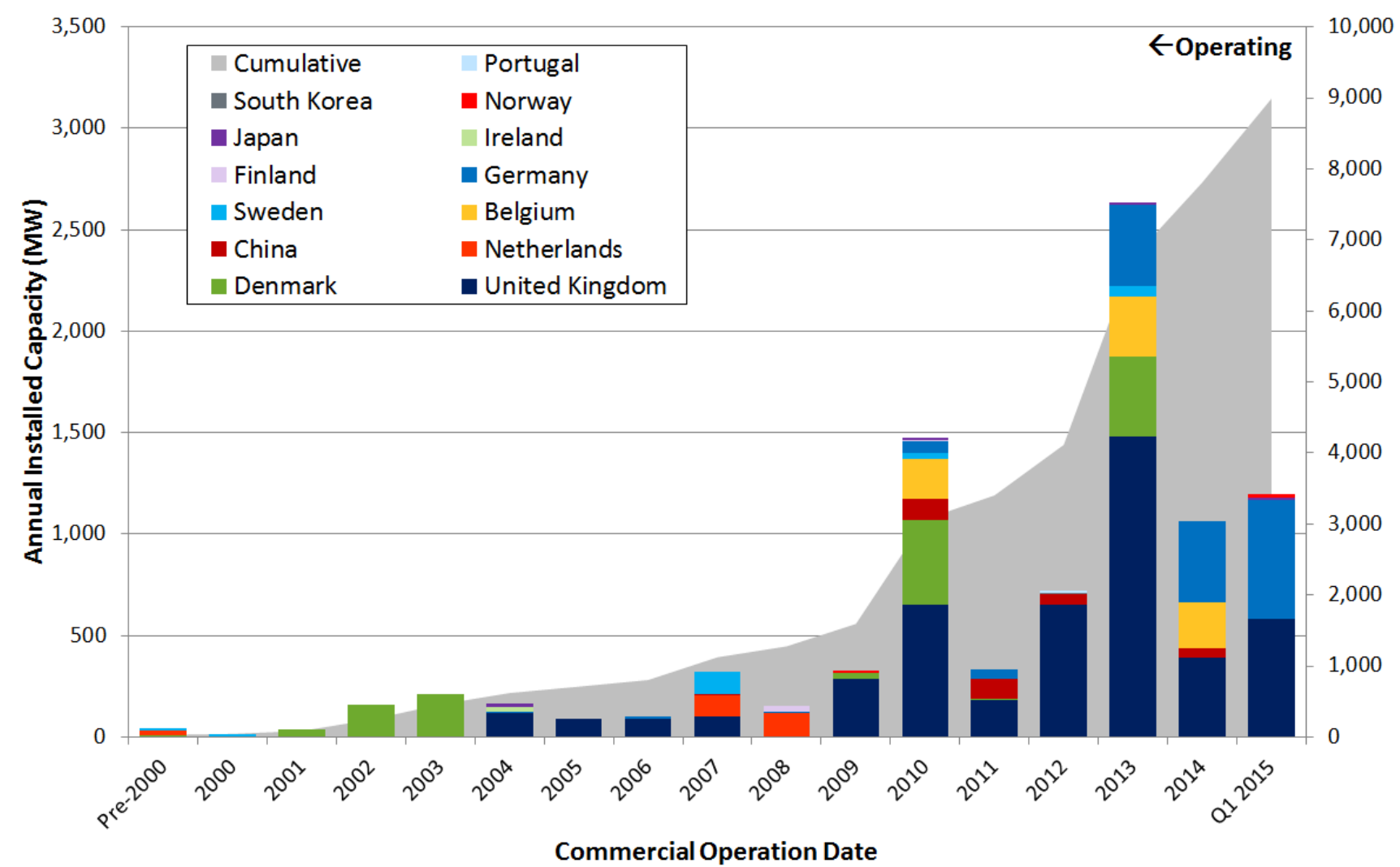

Figure 1. Operating global offshore wind capacity (annual and cumulative)

In 2014, the global offshore wind industry commissioned a total of 1,062 MW, representing an approximate $60 \%$ decrease from 2013 deployments. This decrease was mostly a result of challenging weather conditions in the North Sea and grid connection issues that delayed the commissioning of many projects. Germany led the commissioning of offshore projects with 402 MW, followed by the United Kingdom (389 MW), Belgium (288 MW), and China (50 MW).

In spite of a sluggish year in 2014, 2015 is expected to be a record year for global offshore wind deployments, with 3,996 MW on track to begin operations. In the first half of 2015, the industry commissioned 1,190 MW of this capacity, bringing the total current installed capacity to 8,990 MW worldwide. Approximately $96 \%$ of this capacity was installed in Europe, with the remainder installed in Asia. Although not shown in Figure 1, the cumulative global capacity is expected to reach 11,800 MW by year-end 2015 .

\subsection{Long-Term Offshore Wind Market Potential}

Figure 2 shows the capacity of the global operating as well as the announced development pipeline for offshore wind projects by region. This figure does not provide information about the likely timing of developments within the long-term pipeline, but provides overall announced capacity. Generally, projects that are more advanced within the pipeline are likely to be installed earlier than those that are less mature; however, international differences in regulatory structure can result in a wide range of development timelines. Sections 1.5 and 1.6 provide additional details about the near-term project pipeline, where the COD is expected to occur before 2020 . 


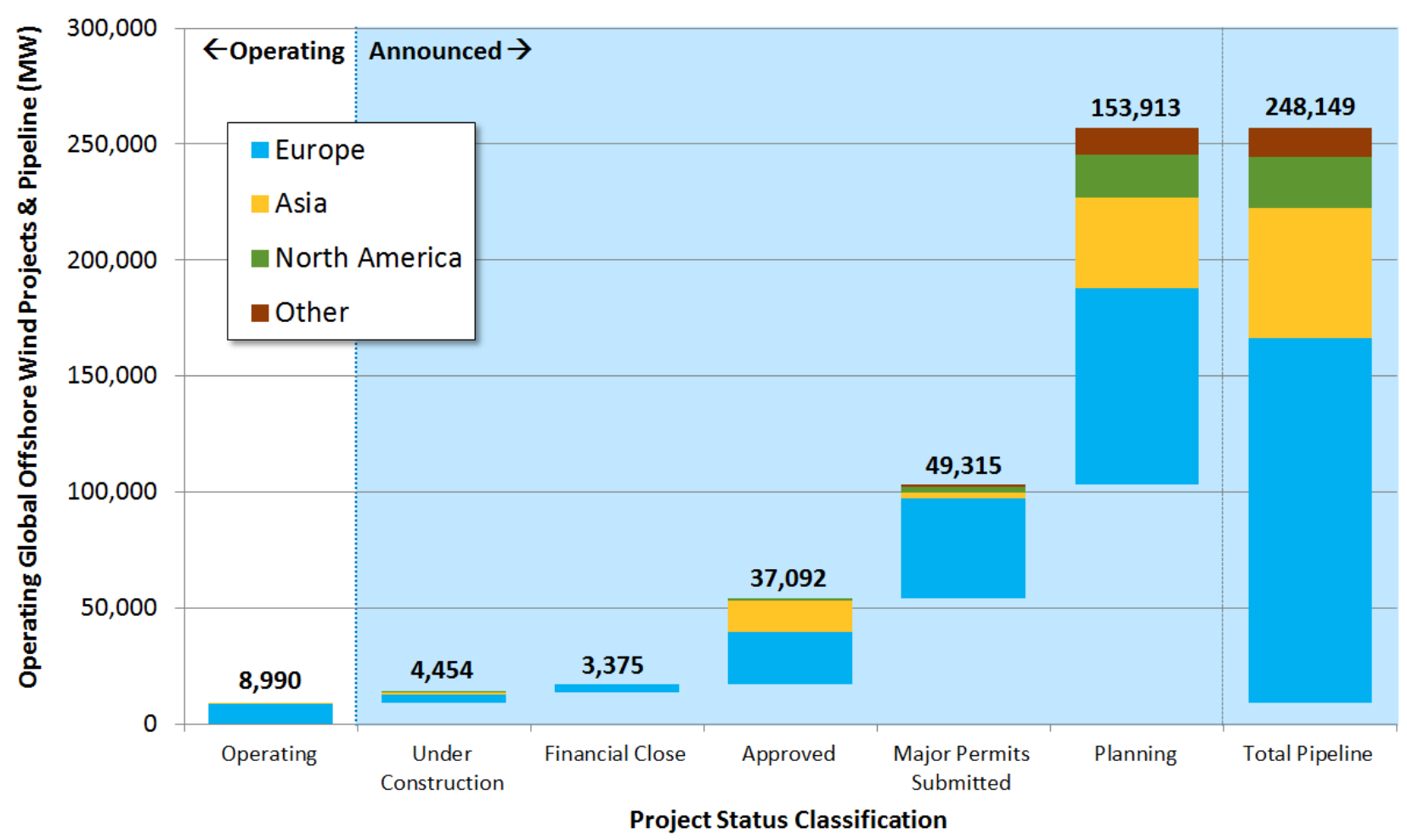

Figure 2. Operating and development pipeline for offshore wind projects by region

The offshore wind project pipeline includes projects that are under construction, at financial close, have been approved, have submitted major permits, and are undergoing planning. This classification is intended to adhere to the project phases defined in Table 1; however, because of differences in international regulatory processes, inconsistencies may occasionally arise. Note that the global project pipeline combines the U.S. status categories "planning - early-stage" and "planning - site control" into a single category called "planning." NREL does not track the distinction for global projects because it is not always relevant under regulatory structures for other national markets. The pipeline is segmented into four regional categories: Europe, North America, Asia, and Other. The "Other" category includes several early-stage projects that have been announced in Latin America and Oceana.

The total estimated global offshore wind pipeline currently totals nearly 250,000 MW of capacity, with approximately $8,990 \mathrm{MW}$ of operational capacity. Approximately $63 \%$ of the projects in the identified pipeline are located in Europe, $23 \%$ in Asia, $9 \%$ in North America, and $5 \%$ in the rest of the world (Other).

\subsection{The Offshore Wind Market in 2015}

The projects under construction are the most certain and illustrate the composition of the market over the next 1 or 2 years. The pipeline shows that there is $4,452 \mathrm{MW}$ of new capacity currently under construction. Figure 3 compares the global fleet of operating projects to the projects currently under construction by country. 


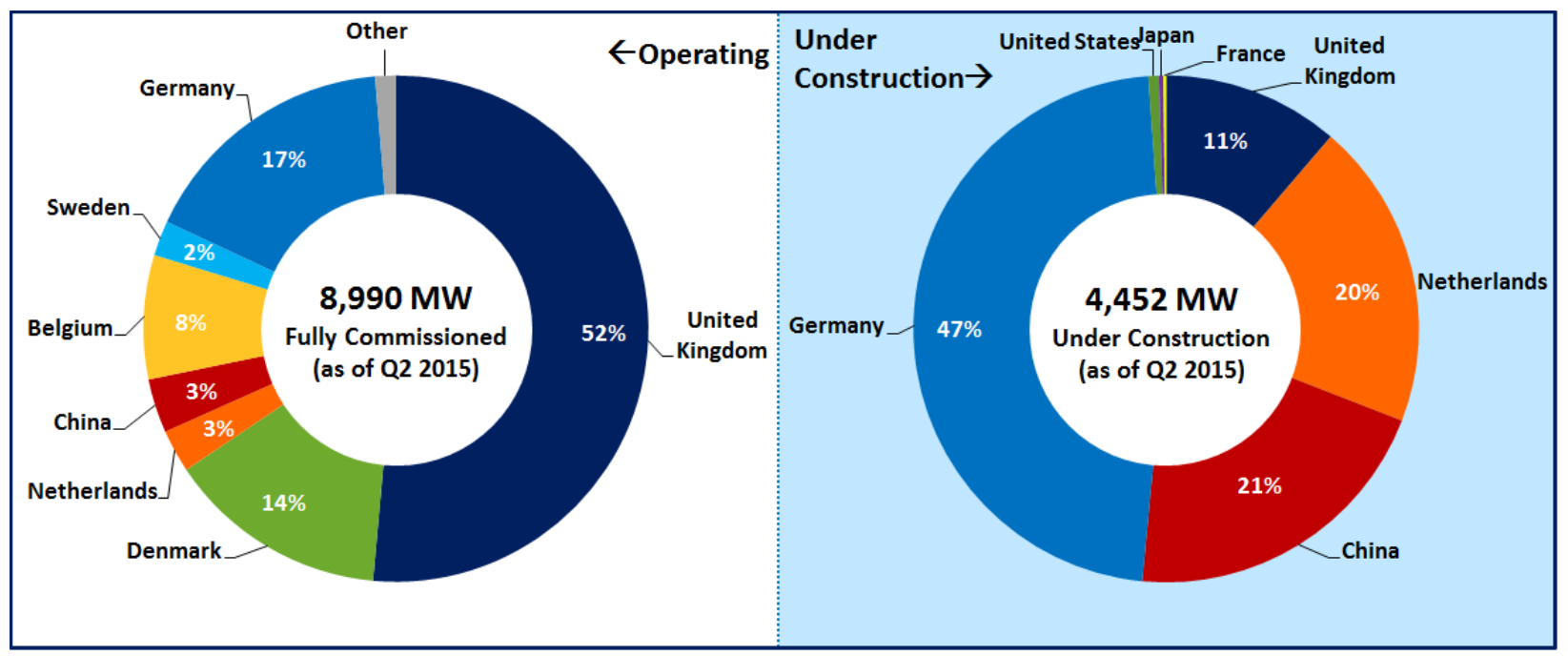

Figure 3. Comparison of national market share for operating versus under construction projects

Table 3 summarizes the fully commissioned offshore wind capacity and the new offshore wind capacity under construction, by country, as of June 30, 2015.

Table 2. Summary of Operating and Under Construction Offshore Wind Projects by Country

\begin{tabular}{|lcccc|}
\hline & Operating (MW) & Under Construction (MW) & Total (MW) & Rank \\
\hline United Kingdom & 4,625 & 503 & 5,128 & 1 \\
Germany & 1,505 & 2,108 & 3,613 & 2 \\
Denmark & 1,271 & 0 & 1,271 & 3 \\
China & 310 & 918 & 1,228 & 4 \\
Netherlands & 247 & 873 & 1,120 & 5 \\
Belgium & 712 & 0 & 712 & 6 \\
Sweden & 202 & 0 & 202 & 7 \\
Japan & 52 & 13 & 64 & 8 \\
Finland & 32 & 0 & 30 & 9 \\
United States & 0 & 30 & 30 & 10 \\
Ireland & 25 & 0 & 25 & 11 \\
France & 0 & 8 & 8 & 12 \\
South Korea & 5 & 0 & 5 & 13 \\
Norway & 2 & 0 & 2 & 14 \\
Portugal & 2 & 0 & 2 & 15 \\
\hline Total & $\mathbf{8 , 9 9 0}$ & $\mathbf{4 , 4 5 2}$ & $\mathbf{1 3 , 4 4 2}$ & \\
\hline
\end{tabular}

Note: Totals may not sum due to rounding.

The United Kingdom leads the offshore wind market in annual deployment and has the highest cumulative capacity, but the German market is seeing rapid growth. As shown in Figure 3, Germany represents approximately $47 \%$ of the global offshore wind projects under construction (2,108 MW), followed by China (918 MW), the Netherlands (873 MW), and the United Kingdom (503 MW). The United States has its first project under construction (BIWF), with 30 MW of capacity expected to be operational by fall 2016. 


\subsection{The Offshore Wind Market Through 2020}

Figure 4 shows the global offshore wind project pipeline through 2020, including all offshore wind projects that have announced a COD on or before 2020 (regardless of development status). Annual projected capacity additions are shown by country and the grey area denotes the cumulative projections. Note that U.S. market trends and project developments are described in detail in Section 3. Figure 4 can be reviewed with Figure 1 to get a sense of the full offshore wind project history and outlook through 2020 .

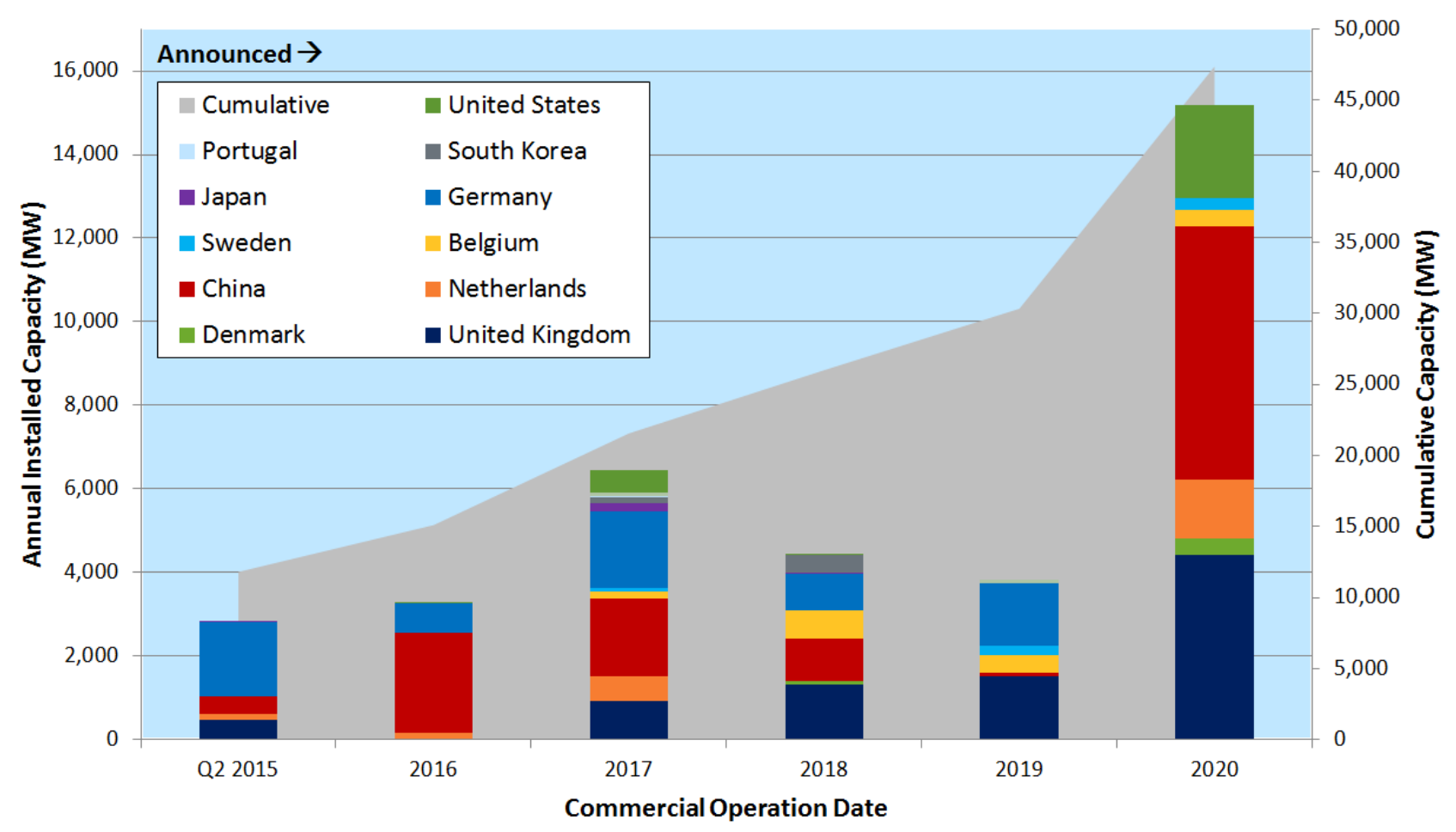

Figure 4. Global offshore wind project pipeline through 2020 (by country)

Figure 4 indicates that $38,397 \mathrm{MW}$ of installed capacity is expected to be commissioned by 2020 , which would bring the cumulative installed capacity to $47,387 \mathrm{MW}$. China and the United States are expected to contribute a greater share of the market by 2020. As mentioned earlier, individual projects have not been evaluated to determine the likelihood of achieving their announced schedules, therefore this report should not be treated as a forecast without conducting further investigation.

Global projections indicate a long-term market potential of nearly 250,000 MW of offshore wind based on a stream of announced projects that are making their way through the pipeline. With 4,452 MW under construction and another $40 \mathrm{GW}$ either under contract or approved, the global industry appears to be signalling positive growth. The recent progress towards reducing costs is a good sign for the industry because it indicates that the technology is likely to be increasingly competitive with other sources of low-carbon generation and therefore less reliant on public subsidies in the post-2020 timeframe. Policy support is, however, uncertain beyond 2020, and so it is unclear what portion of the projects in the pipeline will actually be constructed. 


\section{Overview of U.S. Offshore Wind Development}

The U.S. offshore wind industry has seen a range of progress and challenges over the past year and a half. This section highlights some of the key events that may impact the domestic industry's progress. It also describes the U.S. offshore wind development pipeline, which includes 15,650 MW of proposed projects, and highlights the headway that the U.S. Department of the Interior's Bureau of Ocean Energy Management (BOEM) has made towards defining and leasing tracts of subsea land to offshore wind project developers. Finally, this section provides a summary of projects that have obtained site control including private, commercial projects and projects funded under DOE's Advanced Technology Demonstration (ATD) program, which is composed of three unique flagship projects that are designed to reduce the cost of energy by developing and demonstrating innovative technology.

\subsection{U.S. Offshore Wind Industry Status}

Although there are still no operating offshore wind projects in the United States, global and national trends are setting the stage for the launch of a domestic industry over the next few years. Lower global cost projections and maturing markets in Europe and Asia have signaled the viability of the technology to prospective U.S. offshore wind developers and other stakeholders. In March 2015, Deepwater Wind closed financing on its \$360-million BIWF, which is now under construction in Rhode Island. If successful, this project is poised to be the stepping stone to a much larger national offshore wind industry.

In March 2015, DOE published the Wind Vision: A New Era for Wind Power in the United States (DOE 2015). The report examines a detailed, long-term, broad-reaching scenario for the United States to establish $35 \%$ of its electricity from wind energy by 2050 , using both land-based and offshore wind. The Wind Vision scenario estimates that $86 \mathrm{GW}$ of offshore wind could be deployed in the nation by 2050 and provides a high-level road map of the actions necessary to realize this scenario. The analysis shows that offshore wind could contribute to all regions of the United States, including the North and South Atlantic Ocean, the Gulf of Mexico, the Great Lakes, and the Pacific Ocean (including California, Oregon, Washington, and Hawaii), although varying regional market conditions and technology requirements may dictate a wide range of deployment timelines.

BOEM continues to make progress with its planning and leasing processes, especially in the mid- and north Atlantic regions. Ten years after BOEM was granted jurisdiction over renewable energy development on the Outer Continental Shelf $(\mathrm{OCS})^{8}$, its rigorous process of stakeholder engagement and intergovernmental coordination has resulted in the designation of offshore wind energy areas (WEAs); acreage that could support enough offshore wind capacity to develop a commercial industry in the United States (Farquhar 2011).

In the past year, the nation's offshore wind energy industry has experienced some notable advancement in the status of projects, as well as progress in state and federal policy. The industry

\footnotetext{
${ }^{8}$ U.S. waters between 3 nautical miles $(5.5 \mathrm{~km})$ and 200 nautical miles $(370.4 \mathrm{~km})$ from shore, not including the Great Lakes (or between 9 nautical miles [16.7 km] and 200 nautical miles [370.4 km] for Texas and Florida). BOEM was granted jurisdiction as the Minerals Management Service in August 2005 under the Energy Policy Act.
} 
has also had some setbacks, as projects in the pipeline have encountered a range of political, legal, and economic issues. The most notable events and achievements that could impact the U.S. offshore wind industry are summarized as follows.

Significant recent state and national policy developments include:

- The Obama Administration and the Environmental Protection Agency issued final Clean Power Plan regulations in August 2015. The Clean Power Plan is designed to reduce the nation's carbon dioxide emission levels by 32\% from 2005 levels by 2030 . The plan indicates a strong policy directive that could increase the national demand for renewable generation (The White House 2015).

- Senators Tom Carper (Delaware) and Susan Collins (Maine) introduced the Incentivizing Offshore Wind Power Act on July 9, 2015, a bipartisan initiative, which, if enacted, will provide critical financial incentives to encourage investment in offshore wind energy; this legislation would create an investment tax credit that is redeemable for the first 3,000 MW of offshore wind facilities placed into service (North American Windpower 2015a).

- Governor David Ige signed a bill into law in June 2015 that strengthens Hawaii's commitment to clean energy by directing the state's utilities to generate $100 \%$ of their electricity sales from renewable energy resources by 2045; this law is considered a bold step because it makes Hawaii the first state in the nation to set a $100 \%$ renewable portfolio standard for the electricity sector, and comes only months after two offshore wind projects totaling over $800 \mathrm{MW}$ were proposed.

- California's Governor Jerry Brown issued an executive order in April 2015 to reduce greenhouse gases to $40 \%$ of 1990 levels, thus requiring that the state reach $50 \%$ renewable electric energy by 2030 . The State Assembly passed the Clean Energy and Pollution Reduction Act in September 2015, which codifies the 50\% renewable portfolio standard and requires a 50\% increase in energy efficiency savings. This legislation may accelerate market development for offshore wind in California (Brown 2015; De León and Leno 2015).

- Patricia Haddad, the third ranking member of the Massachusetts House of Representatives, introduced a bill in January 2015 that will require utilities in the state - starting in 2016 - to conduct periodic joint solicitations for offshore wind energy projects off its coast. The bill would require utilities to contract for 8.5 million MWh annually by 2030 (Kessler 2015).

- The New Jersey Board of Public Utilities (BPU) announced that it would hire a consultant to help it design criteria for offshore wind projects to qualify for offshore renewable energy certificates (ORECs), which are the prescribed financial mechanism to support the legislative mandate of achieving 1,100 MW by 2020 (Johnson 2015).

- New York State announced a State Energy Plan that sets goals of 1) reducing carbon emissions by 40\% from 1990 levels, 2) increasing the share of electricity generated from renewable sources to $50 \%$ by 2030 , and 3 ) reducing building electricity consumption by $23 \%$ from 2012 levels. Although the plan is currently nonbinding (the targets would need to be codified by the legislature), it provides direction to state agencies, including the New York Public Service Commission, the New York State Energy Research and Development Authority, and the New York Power Authority to create conditions that would meet these targets (Sen 2015). 
- New York City announced a goal of obtaining $100 \%$ of electricity consumed by the city government from renewable sources as part of its strategy to reduce carbon emissions by $80 \%$ by 2050 . It released a Request for Information to identify renewable generation capacity that could help the city to meet its goal, prioritizing new projects over existing projects (de Blasio 2015).

- The University of Delaware's Special Initiative on Offshore Wind conducted a study (released in March 2015) for the New York State Energy Research and Development Authority that offers a roadmap of key strategic steps New York can take to reduce the costs of offshore wind power over the next decade (McClellan 2015).

Significant offshore wind planning and leasing developments include:

- BOEM completed lease auctions in Maryland and Massachusetts in August 2014 and January 2015, respectively, which added $1,566 \mathrm{~km}^{2}$ to the total offshore area in the United States under site control by private developers. An additional two lease areas in deeper water and farther offshore Massachusetts did not receive any bids (DOI 2015a).

- BOEM identified the WEAs offshore North Carolina and New Jersey, which include sufficient area to support over 5,000 MW of offshore wind capacity. The agency has also defined a Call for Information and Nominations area (precursor to a WEA) in New York that could support approximately 1,000 MW of capacity.

- DONG Energy, a Danish company that has built $30 \%$ of all operating global offshore wind projects, was assigned a lease area in the Massachusetts WEA and indicated that construction could begin after 2020 (DONG Energy 2015). The entrance of DONG Energy into the market inspires fresh confidence about the future of the U.S. offshore wind industry.

- BOEM issued a research lease to the Virginia Department of Mines, Minerals and Energy for the proposed 12-MW Virginia Offshore Wind Technology Advancement Project (VOWTAP), which is under development by a consortium led by Dominion Virginia Power (BOEM 2014).

- Principle Power, Inc. received a determination of no competitive interest from BOEM for the up-to-25-MW WindFloat Pacific project offshore Oregon, which provides the project with the ability to proceed with site development work (Federal Register 2014).

- Lake Erie Energy Development Corporation (LEEDCo) has formed a partnership with five counties in Ohio and Pennsylvania to develop offshore wind projects that benefit the region. By virtue of the Ohio Submerged Lands Act, each of these partner counties in Ohio has the authority to sign offshore wind leases for adjacent waters, which suggests that LEEDCo has exclusive development rights for $8,900 \mathrm{~km}^{2}$ in the Great Lakes (North American Windpower 2015b).

Significant events related to the progress of projects within the development pipeline include:

- Deepwater Wind began construction at sea on the 30-MW BIWF in Rhode Island; substructure installation is scheduled to be complete by fall of 2015, with turbines scheduled to be installed and commissioned by fall of 2016.

- Massachusetts utilities, National Grid and EVERSOURCE (formerly NSTAR), delivered purported notices of cancellation of their PPAs with the 468-MW Cape Wind project after it 
allegedly failed to meet a December 31,2014 , deadline to obtain financing, start construction, or submit financial collateral. Cape Wind contests the effect and lawfulness of such notices of termination and is expected to challenge this decision; however, the future of the project is uncertain at this time.

- DOE announced in May 2014 that Dominion Virginia Power, Fishermen's Energy, and Principle Power were selected as the three finalists for its ATD program. Two other projects, the 18-MW Icebreaker project offshore Ohio and the 12-MW Aqua Ventus project offshore Maine, were granted continued funding to mature innovative design concepts.

- The New Jersey BPU rejected the 24-MW Fishermen's Atlantic City Windfarm application for its OREC program citing concerns about the net economic benefits to the state; Fishermen's Energy has now filed an appeal to the New Jersey State Supreme Court and a ruling is expected in early 2016, likely moving the COD to 2018.

- Dominion Virginia Power announced in the spring of 2015 that it will delay the 12-MW VOWTAP after bids for construction came in over $60 \%$ above the initial estimates; Dominion is working with its partners to evaluate approaches for reducing the cost of the project, which will likely delay its COD to 2018 (Del Franco 2015b).

- U.S. Wind began conducting baseline geophysical and geotechnical surveys in summer 2015 to develop a site assessment plan of its offshore Maryland OCS leases (Wheeler 2015).

- Principle Power was unable to secure authorization to negotiate a PPA for the up-to-25-MW WindFloat Pacific project from the Oregon legislature in the 2015 term, which will likely delay the project's COD beyond 2017. On August 26, 2015, Oregon Governor Kate Brown announced the formation of an Offshore Wind Advisory Committee to "...identify viable pathways to procure the WindFloat Project in Oregon" (Oregon.gov 2015a).

- LEEDCo began geotechnical surveys at the Icebreaker site in summer 2015. The campaign will gather soil core samples to 25 meters $(\mathrm{m})$ deep at each of the turbine locations to inform the design of the suction-bucket foundations (Funk 2015a). LEEDCo also signed an interconnection agreement with the PJM Interconnection in July 2015, which would allow the project to sell power into the regional electric grid (Wagner 2015).

Although this list of industry developments includes some setbacks and progress towards commercial development remains slow, policy support generally appears to be growing across the nation, which could increase demand for offshore wind power in the United States over the long term.

\subsection{U.S. Offshore Leases and Wind Energy Areas}

On the regulatory side, BOEM has made significant progress over the past decade in establishing a safe, transparent, environmentally responsible offshore wind development process. The Energy Policy Act of 2005 granted BOEM the ability to issue leases, easements, and rights-of-way for activities that produce or support the production of energy from sources other than oil and gas. BOEM promulgated its regulations to implement this authority in 2009.

BOEM is working with stakeholders to identify areas on the OCS that appear to have minimal environmental and multiple use conflicts, referred to as WEAs. The delineation of these WEAs is informed by BOEM's Intergovernmental Task Forces, which consist of federal, state, local, and 
tribal government representatives that have jurisdiction over, or could be affected by, offshore wind development. Federal/state interagency cooperation is critical for achieving the U.S. Department of the Interior's objective to develop and implement an efficient and informed offshore wind planning and leasing process.

The development and execution of BOEM's leasing process, allowing private commercial developers to obtain site control, and, ultimately, the right to construct and operate offshore wind facilities, has been a key milestone in moving the U.S. offshore wind industry closer to commercial viability. Site control is a key milestone in the development process because exclusive control allows developers to begin the site investigations necessary to design the project and obtain critical environmental information about the area.

Table 3 summarizes the WEAs that have been designated thus far, as well as the competitive lease auctions results, lease area sizes, potential installed capacities, owner-announced installed capacities, and the lease area values, as determined through BOEM's auction process. The lease areas are sorted into three categories: "issued" means that BOEM and the developer have signed a lease, "proposed" means that a proposed sale notice has been published in the Federal Register, "reviews ongoing" means that BOEM has asked for information about the identified areas and is reviewing comments but has yet to publish a proposed sale notice. 
Table 3. Summary of Awarded Commercial Offshore Leases and Wind Energy Areas

\begin{tabular}{|c|c|c|c|c|c|c|c|c|}
\hline State & \begin{tabular}{|c|} 
Existing or \\
Proposed Lease \\
Area
\end{tabular} & Status & $\begin{array}{c}\text { Lease Issue } \\
\text { Date }\end{array}$ & Lessee & $\begin{array}{l}\text { Area } \\
\left(\mathrm{km}^{2}\right)\end{array}$ & $\begin{array}{c}\text { Estimated } \\
\text { Maximum } \\
\text { Potential } \\
\text { (MW) } \\
\end{array}$ & $\begin{array}{c}\text { Owner- } \\
\text { Announced } \\
\text { Project Size } \\
\text { (MW) } \\
\end{array}$ & $\begin{array}{c}\text { Auction } \\
\text { Value } \\
(\$ 000)\end{array}$ \\
\hline MA & OCS-A 0478 & Issued & $10 / 6 / 2010$ & $\begin{array}{c}\text { Energy } \\
\text { Management Inc. }\end{array}$ & 119 & 468 & 468 & N/A \\
\hline $\mathrm{DE}$ & OCS-A 0482 & Issued & $11 / 16 / 2012$ & Bluewater Wind & 418 & 1,254 & 400 & N/A \\
\hline RI-MA & $\begin{array}{l}\text { OCS-A } 0486 \\
\text { (North) }\end{array}$ & Issued & $7 / 31 / 2013$ & Deepwater Wind & 395 & 1,180 & 1,000 & \multirow{2}{*}{3,838} \\
\hline RI-MA & $\begin{array}{l}\text { OCS-A } 0487 \\
\text { (South) }\end{array}$ & Issued & $7 / 31 / 2013$ & Deepwater Wind & 272 & 820 & - & \\
\hline VA & OCS-A 0483 & Issued & $9 / 4 / 2013$ & $\begin{array}{c}\text { Dominion Virginia } \\
\text { Power }\end{array}$ & 456 & 1,370 & 2,000 & 1,600 \\
\hline MD & $\begin{array}{l}\text { OCS-A } 0489 \\
\text { (North) }\end{array}$ & Issued & $8 / 19 / 2014$ & U.S. Wind & 132 & 400 & 250 & \multirow{2}{*}{8,701} \\
\hline MD & $\begin{array}{c}\text { OCS-A } 0490 \\
\text { (South) }\end{array}$ & Issued & $8 / 19 / 2014$ & U.S. Wind & 190 & 570 & 250 & \\
\hline MA & OCS-A 0500 & Issued & $1 / 29 / 2015$ & $\begin{array}{l}\text { DONG Energy } \\
\text { Massachusetts }\end{array}$ & 759 & 2,280 & 1,000 & 281 \\
\hline MA & OCS-A 0501 & Issued & $1 / 29 / 2015$ & OffshoreMW & 675 & 2,030 & 400 & 167 \\
\hline NJ & $\begin{array}{l}\text { OCS-A } 0498 \\
\text { (North) }\end{array}$ & Proposed & 2015 & - & 742 & 2,230 & - & - \\
\hline NJ & $\begin{array}{l}\text { OCS-A } 0499 \\
\text { (South) }\end{array}$ & Proposed & 2015 & - & 649 & 1,950 & - & - \\
\hline $\mathrm{NC}$ & Kitty Hawk WEA & Reviews Ongoing & TBA & - & 495 & 1,490 & - & - \\
\hline NC & $\begin{array}{l}\text { Wilmington } \\
\text { West WEA }\end{array}$ & Reviews Ongoing & TBA & - & 209 & 630 & - & - \\
\hline NC & $\begin{array}{c}\text { Wilmington East } \\
\text { WEA }\end{array}$ & Reviews Ongoing & TBA & - & 541 & 1,620 & - & - \\
\hline Total & & & & & 6,052 & 18,292 & 5,768 & 14,587 \\
\hline
\end{tabular}

Note: Assumes an average capacity density of $3 \mathrm{MW} / \mathrm{km}^{2}$ based on spacing of 9 to 10 rotor diameters developed (Musial et al. 2013a and Musial et al. 2013b). Actual capacity will depend on the results of site evaluations, turbine rotor size, project size, and market considerations. In most cases the maximum potential capacity in Table 3 will be larger than the announced capacity for the actual specific project designed after obtaining site control.

To date, BOEM has issued two leases on a noncompetitive basis and conducted four competitive auctions for WEAs along the Atlantic Coast. In August 2014, BOEM announced that U.S. Wind was the winning bidder for two lease areas delineated offshore Maryland, and, in January 2015, BOEM announced that Renewable Energy Systems (RES) Americas and OffshoreMW had each won one lease area offshore Massachusetts. Analysis of these areas in Maryland and Massachusetts shows 5,280 MW of potential installed capacity (assuming full development at 3 $\mathrm{MW} / \mathrm{km}^{2}$ ). After award, however, developers announced project sizes that total approximately 1,900 MW. Later, DONG Energy, one of the principal offshore wind developers in Europe, was assigned ownership of the RES Americas' lease offshore Massachusetts.

So far, BOEM has issued leases for development zones that could support 10,372 $\mathrm{MW}^{9}$ of potential capacity, resulting in cumulative offshore wind lease sales of more than $\$ 14.5$ million.

\footnotetext{
${ }^{9}$ Capacity estimates for BOEM wind energy areas are based on a capacity density of $3 \mathrm{MW} / \mathrm{km}^{2}$, which corresponds to turbine spacing between 9 and 10 rotor diameters if the entire area was developed. Typical wind plants may elect to use wider spacing. In Europe, the average spacing is less than 8 rotor diameters (Musial et al. 2013a; Musial et al. 2013b).
} 
After award, developers have refined project size estimates, reducing total capacity under development in these areas to 5,768 MW.

A proposed sale notice for the New Jersey WEA, which could support up to 4,180 MW, was published in July 2014 and the competitive auction is expected to be held in fall 2015.

Additionally, BOEM is conducting environmental reviews of the WEAs identified offshore of North Carolina that have the potential to support an extra 4,730 MW of capacity, but the schedule for these potential auctions has not been announced.

No WEAs have been identified offshore Maine, New Hampshire, Connecticut, and New York, or offshore states south of North Carolina, the Gulf Coast, or on the Pacific Coast. BOEM is working with New York and South Carolina Task Forces to identify potential WEAs offshore of those states. Some projects in these regions are moving ahead, however, with unsolicited proposals to BOEM, or within state-level regulatory processes for sites in state waters. For example, BOEM received unsolicited lease requests from AW Hawaii Wind, LLC (AW Hawaii) for two floating wind projects in Hawaii totaling $816 \mathrm{MW}$.

Figure 5 provides three maps of up-to-date federal leasing activity for commercial and research purposes in the Northeast, Mid-Atlantic, and Southeast regions of the United States, respectively. 

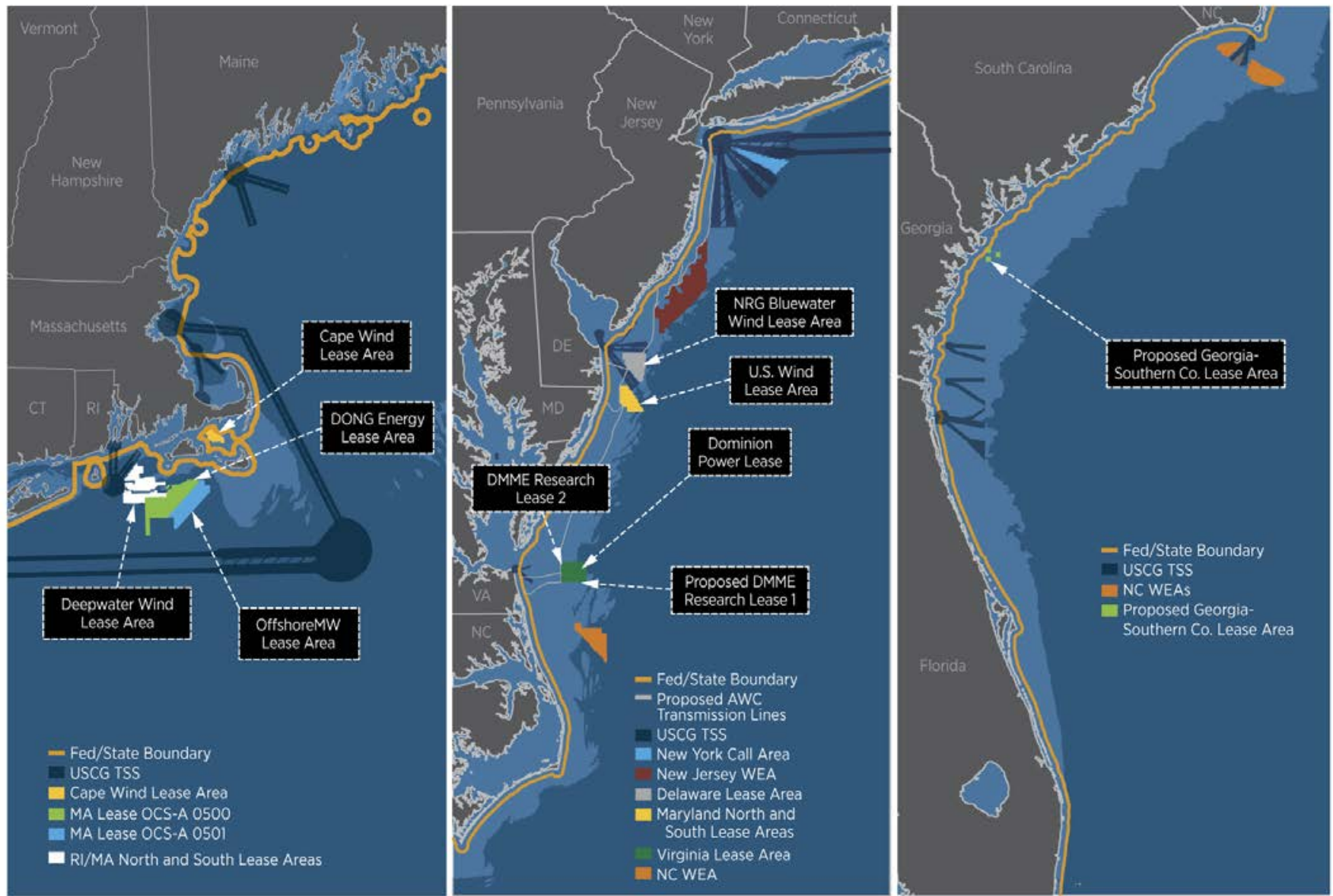

\section{Bathymetry}

Up to 30 meters More than 30 meters

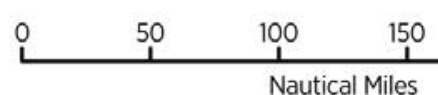

200 250

Note: Acronyms used in graphic: U.S. Coast Guard (USCG); Coast Guard Traffic Separation Schemes (TSS); Wind Energy Area (WEA) Interim Policy (IP); Virginia Department of Mines, Minerals, and Energy (DMME); Atlantic Wind Connection (AWC); Florida Atlantic University (FAU); Offshore Wind Alliance (OWA).

Figure 5. Current U.S. federal offshore wind leases, WEAs, and call areas on the Atlantic OCS. Illustration by Josh Bauer, NREL 


\subsection{U.S. Offshore Wind Project Development Pipeline}

The U.S. offshore wind project development pipeline includes 21 projects totaling 15,650 MW of potential installed capacity. Developers have obtained site control over 13 projects totaling $5,939 \mathrm{MW}$ of this capacity, including projects located in state waters. ${ }^{10}$ For OCS projects, site control is granted by BOEM, which identifies potential offshore wind development zones through an extensive stakeholder engagement process, and then typically holds competitive auctions to award development rights. Three active projects in the development pipeline are located in state waters and have been granted site control by the appropriate state agency, including the 30-MW BIWF in Rhode Island, the 24-MW Fishermen's Atlantic City Windfarm in New Jersey, and the 12-MW Aqua Ventus project in Maine.

For this report, the determination of project size was based on the developer's announced project size. In cases in which the project size is not known, capacity was estimated based on the total potential capacity of the WEAs as provided in Table 3. This method was carried over for earlystage projects where WEAs are not yet under site control but their boundaries have been defined by BOEM. As such, this process will have the tendency to overestimate the total capacity in the early phases because it is likely that full WEA development at a $3-\mathrm{MW} / \mathrm{km}^{2}$ density may not occur. Capacity limitations may include required restrictions to protect environmental resources, cultural resources, and other uses of the lease area; unsuitable seabed conditions; or array optimization tradeoffs; or those imposed by the off-take agreement or investors.

Figure 6 shows the capacity of U.S. projects in the pipeline broken down by status and state. The figure can be used to compare the U.S. pipeline to the global pipeline shown in Figure 2.

\footnotetext{
${ }^{10}$ A summary of each of the 21 U.S. offshore projects in the pipeline is contained in the appendices. The summaries are grouped into tables by project phase according to the criteria described in Table 1. Appendix A presents the status of three projects that are under construction or approved, Appendix B describes four projects in the permitting phase, Appendix C covers the six U.S. projects in the planning phase with site control, and Appendix D describes the remaining eight U.S. projects in the early-stage planning phase without site control.
} 


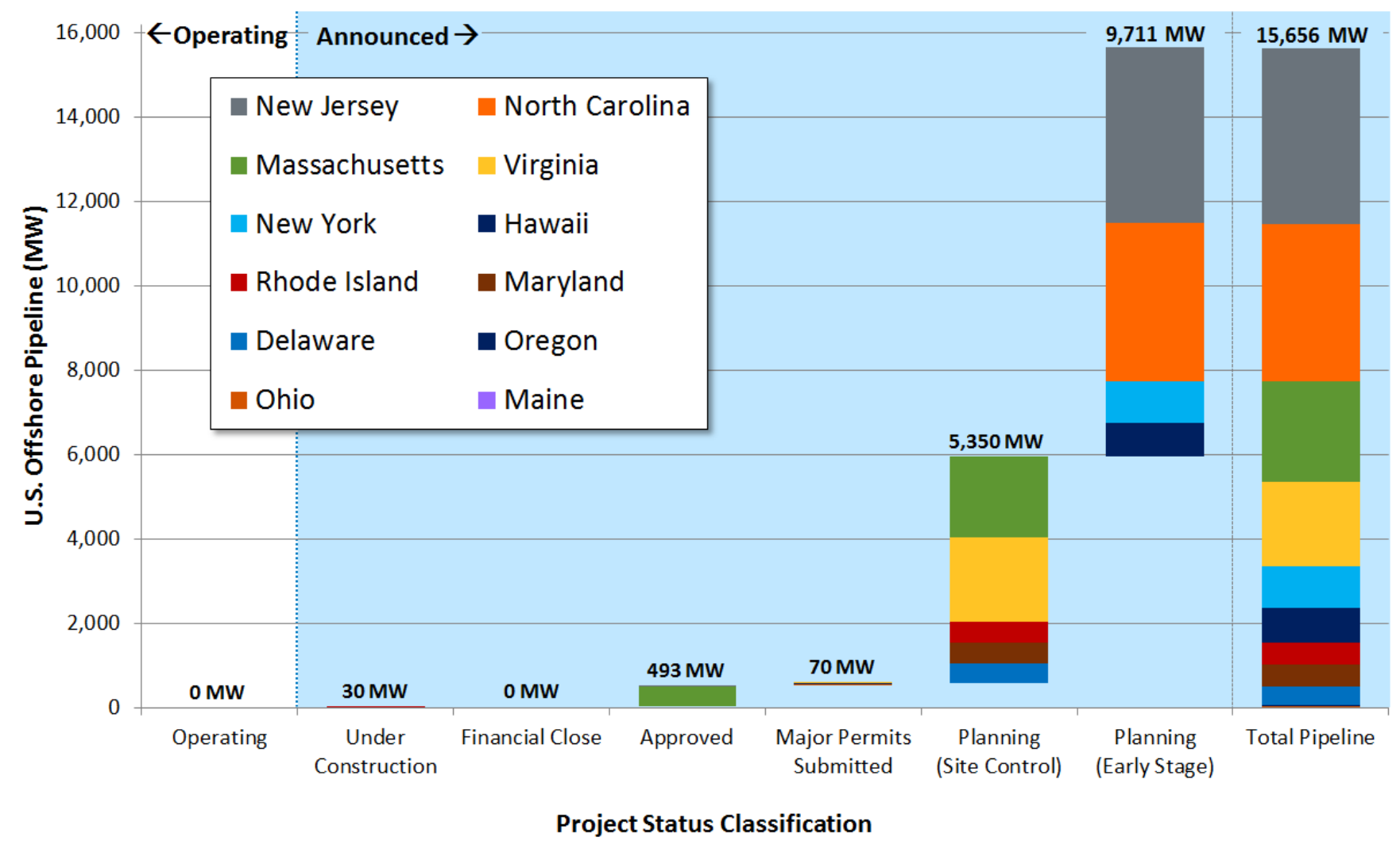

Figure 6. U.S. offshore wind pipeline by state

Figure 7 shows a map of the 21 U.S. project locations and development zones that make up the offshore pipeline in 12 states in the contiguous United States and Hawaii. Color-coded bubbles depict the scale and stage of advancement of the individual projects. Figure 8 shows the U.S. project pipeline capacity broken down by state and development status. 


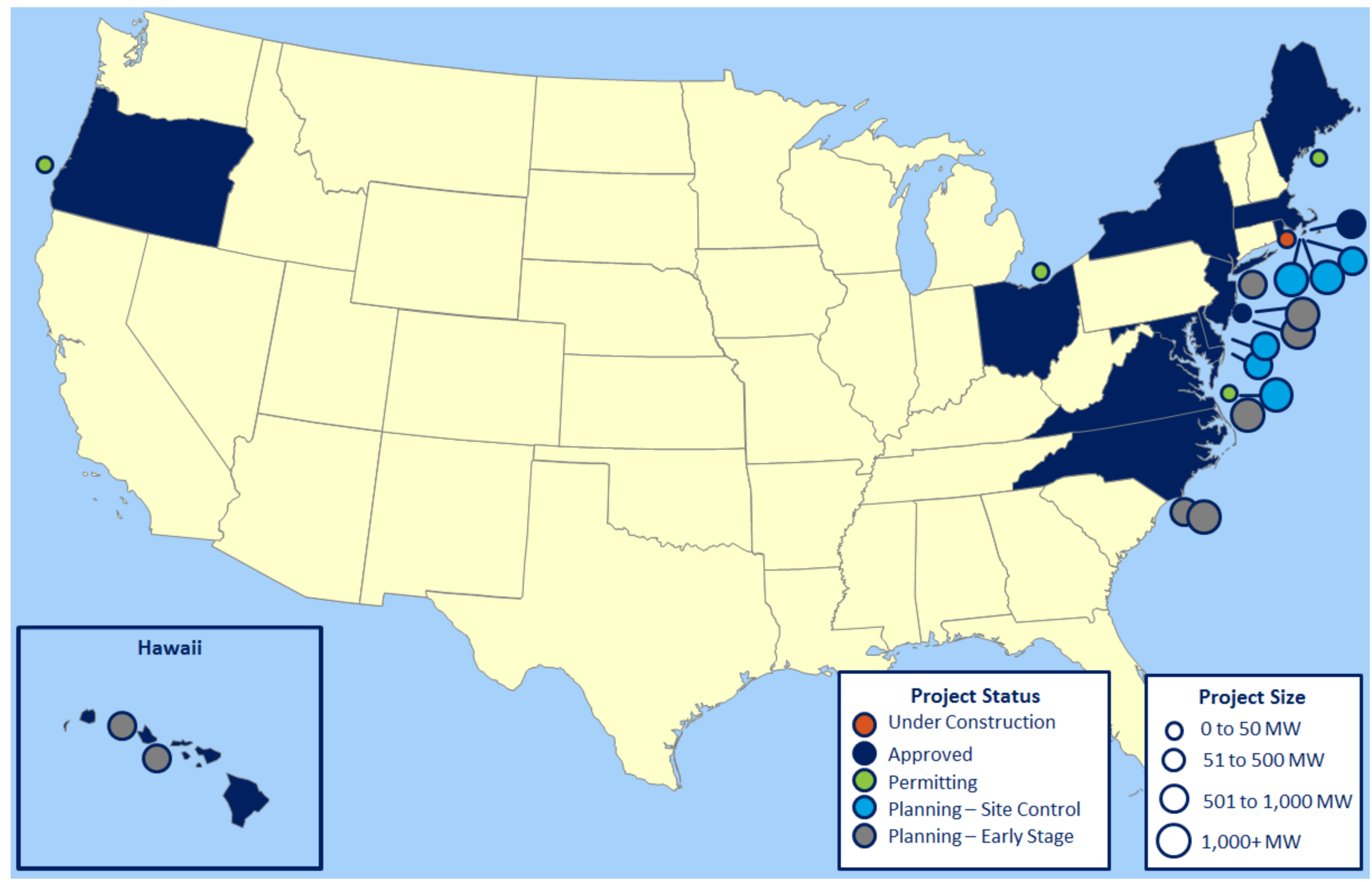

Figure 7. Map of U.S. offshore wind project pipeline 


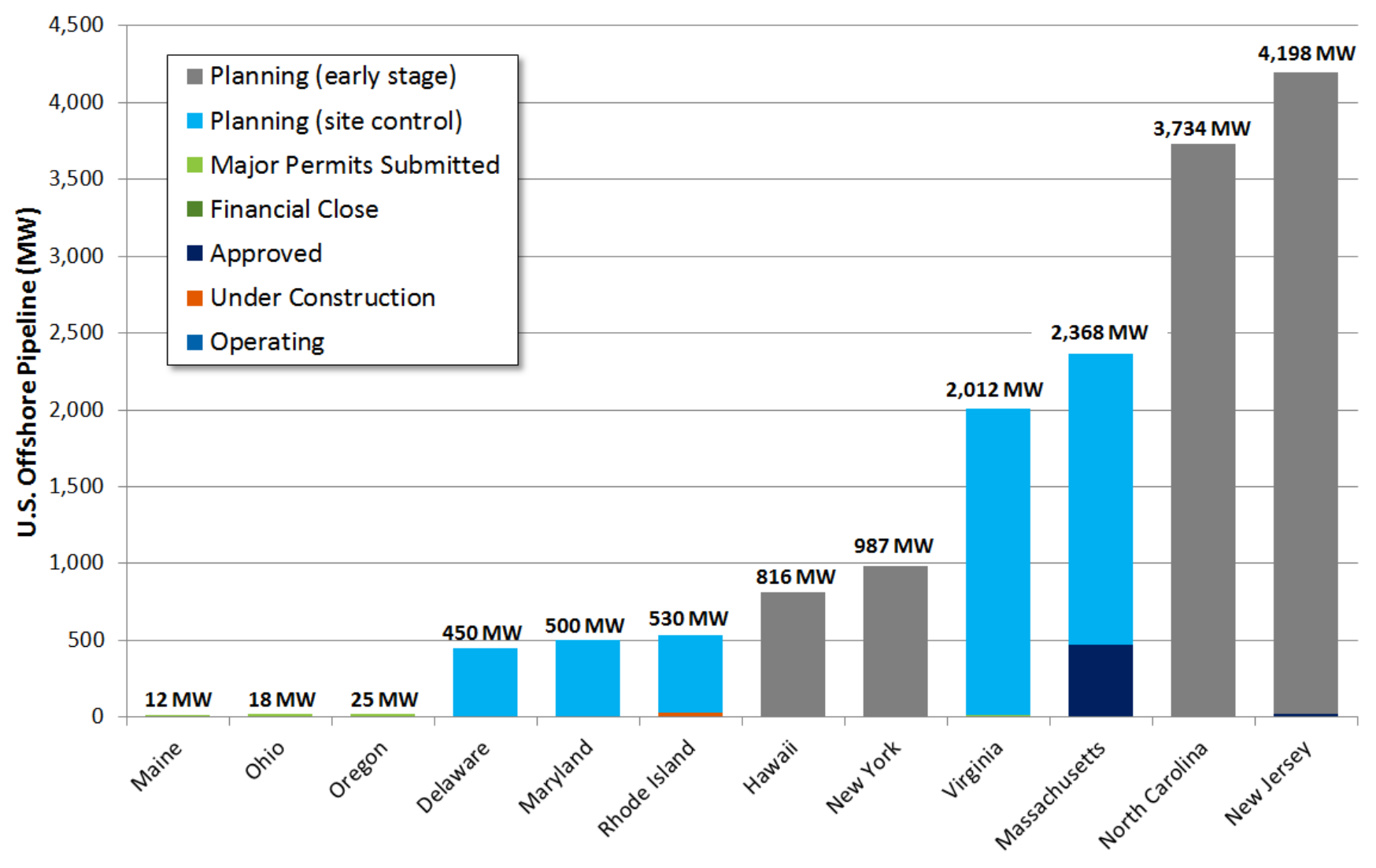

Figure 8. U.S. offshore wind project pipeline by state and development status

Figure 7 and Figure 8 show that most of the current offshore wind projects in the U.S. pipeline are concentrated in the North Atlantic region, although resource assessments indicate that there are viable offshore wind resources in other parts of the United States, such as in the South Atlantic, Great Lakes, Gulf of Mexico, and Pacific regions (Schwartz et al. 2010). Offshore wind is favorable in the North Atlantic region because of its:

- Status as having the highest wind speeds in the country for fixed-bottom sites

- Metocean and bottom conditions that resemble many North Sea sites, allowing developers to tap into global industry experience

- High population densities and congested energy markets, resulting in higher electricity prices (and an opportunity to help lower those prices)

- Political support from state governments wishing to diversify their energy supply, stimulate economic growth, and gain some measure of energy independence

- Issuance of a lease to Cape Wind Associates for an area offshore Massachusetts, which accelerated federal action and drew attention to the area at an early stage.

Figure 8 also shows that the states with the largest estimated project development pipelines are not necessarily the ones with the most advanced projects. It is expected that the size of potential projects in these states will decrease as projects mature through additional auctions and refinements by the eventual developers. 
One notable change to the U.S. pipeline this year is the absence of Texas, with the removal of the 150-MW Galveston Offshore Wind project (Coastal Point Energy) from the pipeline due to inactivity. Texas, whose state water boundary extends 9 nautical miles from shore, initiated a significant amount of early permitting and leasing activity and awarded several leases a few years ago that could support multiple gigawatts of capacity in state waters. Since 2013, activity in Texas has essentially ceased, with a major setback resulting from the cancellation of the Gulf Offshore Wind pilot project. Subsequently, the developer announced they were cancelling their U.S. Army Corps of Engineers permits for both its demonstration- and commercial-scale projects (ReNews 2014), and no publicly announced efforts to reactivate these projects have occurred.

\subsection{U.S. Offshore Wind Project Updates}

This section provides descriptions and project updates for the 13 U.S. projects that have obtained site control or a more advanced status, with a particular focus on the eight privately financed projects in the U.S. pipeline. Section 3.5 describes the three ATD finalists, as well as two alternative projects that received continuing DOE funding to mature innovative technology concepts, separately to distinguish them from the private commercial projects.

These 13 projects have significant overlap with the 14 "advanced-stage" projects identified by Navigant in the Offshore Wind Market and Economic Analysis report published in 2014 (Hamilton et al. 2014). There are, however, some differences in the composition of projects in the two reports because of additions and attrition within the development pipeline. Additions include the three leases that BOEM issued to U.S. Wind in Maryland, as well as OffshoreMW and DONG Energy in Massachusetts. Attrition within the pipeline occurred for two main reasons. First, interim leases held by Garden State Offshore Energy and Fishermen's Energy for zones offshore New Jersey expired in 2014 and it seems likely that development rights for these zones will be auctioned as part of the New Jersey WEA. Second, two projects, Galveston Offshore Wind offshore Texas and Ocean Offshore Energy offshore of Saint Thomas, were removed as a result of inactivity.

\subsubsection{Block Island Wind Farm}

The 30-MW BIWF project started offshore construction in July 2015 and is likely to be the first operating U.S. offshore wind project, with the COD currently scheduled for the fall of 2016. As part of this project, Deepwater Wind is installing five 6-MW turbines on jacket substructures 5 $\mathrm{km}$ southeast of Block Island, Rhode Island, in water depths averaging $26 \mathrm{~m}$. Besides being the first U.S. commercial offshore wind project, the BIWF promises to reduce electricity prices for the residents of Block Island by $40 \%$ and provide substantial clean energy to the mainland townships of its southern region of Rhode Island (DOI 2015b). Deepwater Wind reached financial close for the BIWF in March 2015 and began installing five four-legged jacket substructures in the summer of 2015. The five 6-MW direct-drive Alstom Haliade turbines and 34.5-kilovolt $(\mathrm{kV})$ cable connecting Block Island to the mainland will be installed in the spring of 2016 (Stromsta 2015a). The installation of the steel truss substructures is shown in Figure 9. 


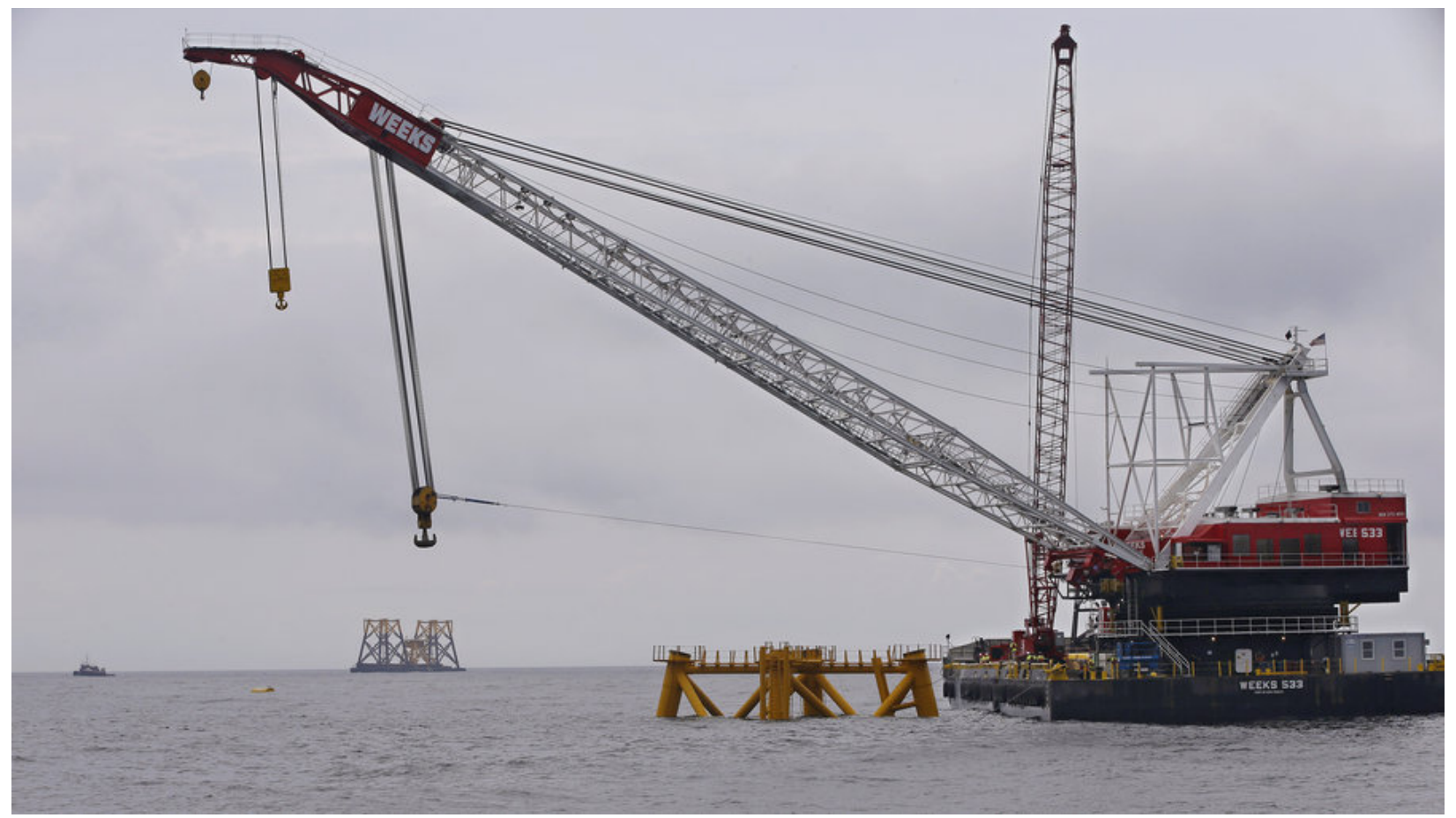

Figure 9. The 30-megawatt Block Island Wind Farm under construction. Photo courtesy of Deepwater Wind

Deepwater Wind is building the BIWF by combining the best available European turbine technology with U.S. manufacturing and installation capabilities. The jackets were designed by Keystone Engineering, fabricated by Gulf Island Marine Contractors in Houma, Louisiana, and incorporate outfitting steel provided by Rhode Island-based Specialty Diving Services. The jackets are being installed by a joint venture consisting of Weeks Marine, based in New Jersey, and Manson Construction, based in Washington (Kuffner 2015a). Deepwater Wind also has contracted with Atlantic Wind Transfers (a division of Rhode Island Fast Ferry) to provide technician transfer services. Atlantic Wind Transfers has ordered the first purpose-built personnel transfer vessel from Blount Boats, which is based on a licensed European design, but will be built in Warren, Rhode Island, (Maritime Executive 2015). Deepwater Wind expects to create 300 jobs throughout the construction phase of the project.

\subsubsection{Cape Wind Offshore Wind Farm}

The 468-MW Cape Wind project, located in Nantucket Sound offshore Cape Cod, was poised to be the first commercial wind plant in the United States, with construction originally scheduled to begin in May 2015; however, National Grid and EVERSOURCE (formerly NSTAR) delivered notices of cancellation of Cape Wind's PPAs in January 2015 after a milestone to obtain financing, start construction, or submit financial collateral was allegedly not met. Cape Wind contests the lawfulness and effect of such notices and believes that the milestones were extended pursuant to the terms of the agreements, citing extensive legal battles that could not be predicted when the contract was executed, and is expected to challenge the decision (Abel 2015).

The project was originally scheduled to start construction on May 1, 2015, but Cape Wind filed a request with the Massachusetts Energy Facilities Siting Board to extend the deadline by 2 years and was granted an interim approval. BOEM also approved Cape Wind's request for a 2-year 
suspension of the operations term of its lease, although the developer remains responsible for annual lease payments (Hopper 2015).

\subsubsection{Deepwater ONE}

Deepwater Wind won the competitive lease auction for the two lease areas within the Rhode Island and Massachusetts Area of Mutual Interest, which is located between Block Island and Martha's Vineyard. This was the first public auction for offshore wind that BOEM held in the United States on July 31, 2013. The two lease areas total $667 \mathrm{~km}^{2}$ and could support the deployment of about 2,000 MW of capacity. The northernmost lease area carried the highest value as it is closest to shore and thought to have shallower and more suitable seabed conditions (Deepwater Wind 2013). The development plan announced by the company includes a regional transmission system linking Long Island, New York, to southeastern New England. The developer has announced that it will begin to survey the lease areas starting in the summer of 2015.

The Long Island Power Authority did not select Deepwater Wind's 210-MW offshore proposal in its latest tender for $280 \mathrm{MW}$ of renewable energy supply, but instead contracted for $122 \mathrm{MW}$ of solar photovoltaics. Regardless, the company has indicated that it is working with stakeholders, including policymakers, regulators, and utilities in Rhode Island, Massachusetts, and New York to create favorable market conditions that could lead to a PPA in the next 12 to 18 months (Stromsta 2015b).

\subsubsection{Dominion Virginia Power}

Dominion Virginia Power won BOEM's second competitive lease auction, which was for the Virginia WEA in September 2013. This lease area totals $456 \mathrm{~km}^{2}$, is located approximately 50 $\mathrm{km}$ offshore Virginia Beach, and has water depths averaging $30 \mathrm{~m}$. Dominion indicates that the zone could support a maximum of 2,000 MW of capacity and plans to develop the lease area using a phased approach, with the potential for commercial operations to begin in the early 2020s (Dominion 2015). Dominion has hired the Danish engineering firm Ramboll to provide initial engineering design work for the site (Recharge News 2015).

VOWTAP, Dominion's 12-MW pilot project and one of the three ATD projects, is described separately in Section 3.5.1.

\subsubsection{U.S. Wind}

U.S. Wind, a subsidiary of the Italian developer Renexia, won BOEM's competitive lease auction for the two adjacent Maryland lease areas, together totaling $322 \mathrm{~km}^{2}$ and located $20 \mathrm{~km}$ offshore Ocean City. Although the project area could support a potential nameplate capacity of almost 1,000 MW, U.S. Wind is considering a smaller size around $500 \mathrm{MW}$ to constrain the project to areas with water depths of no more than $26 \mathrm{~m}$ and minimize costs. U.S. Wind started conducting geotechnical and geophysical surveys on site in the summer of 2015 (Stromsta 2015c).

In 2013, the State of Maryland enacted the Maryland Offshore Wind Energy Act, which creates a "carve-out" for offshore wind generation to supply up to $2.5 \%$ of total retail electricity sales. Offshore wind developers must submit applications to the Maryland Public Service Commission to be approved for ORECs, which are limited to a price of \$190/MWh (in 2012 USD) and a rate impact limit below $\$ 1.65 / \mathrm{MWh}$ for industrial customers. With these assumptions, it is thought that this revenue mechanism could support between $200 \mathrm{MW}$ and $250 \mathrm{MW}$ of offshore wind 
capacity in Maryland (Jenkins 2013). The presence of a revenue mechanism in Maryland contributed to the highest auction values for any offshore wind lease auction held to date and represents nearly $60 \%$ of all revenue that BOEM has generated through competitive offshore wind lease auctions.

\subsubsection{DONG Energy}

RES Americas won BOEM's competitive lease auction held in Massachusetts in January 2015 for the westernmost region of four areas up for auction. The lease area is $759 \mathrm{~km}^{2}$ and is located in federal waters south of Martha's Vineyard. The lease has a development potential of 2,280 MW based on $3 \mathrm{MW} / \mathrm{km}^{2}$; however, because the lease areas in the Massachusetts WEA are large and deep (ranging in depth from 35 to $65 \mathrm{~m}$ ), this capacity estimate may be high.

RES Americas has since sold the development rights to DONG Energy, an offshore wind developer that built 30\% of all operating projects. BOEM approved the transfer on July 18, 2015. As such, DONG Energy announced that their initial plans would be to develop the site for an approximately 1,000-MW wind plant (DONG Energy 2015). The project is expected to begin construction after 2020 .

\subsubsection{OffshoreMW}

OffshoreMW won BOEM's competitive auction for a lease zone that is located approximately 22 $\mathrm{km}$ south of Martha's Vineyard and adjacent to the DONG Energy lease area. ${ }^{11}$ The company, which will lead development activities within the lease area, has entered a partnership with Vineyard Power to form Martha's Vineyard Offshore Wind Alliance. The alliance is structured as a community benefit agreement that aims to develop a community-owned wind project that maximizes the benefits of offshore wind for both Martha's Vineyard and Massachusetts.

Early plans announced by the alliance call for building an approximately 400-MW project that would supply the Vineyard Power Cooperative with up to $100 \mathrm{MW}$ of electricity and export the balance to the mainland. Company representatives indicated that, if the permitting and power marketing process proceeds without challenges, construction on the project could start as early as 2018 (Myrick 2015).

\subsubsection{NRG Bluewater}

Secretary Salazar announced on October 23, 2012, that BOEM reached an agreement on a commercial wind energy lease with NRG Bluewater Wind for a lease area that is located $17 \mathrm{~km}$ off the coast of Delaware. The lease was executed on November 16, 2012; however, Delmarva Power, the prospective off-taker, canceled a PPA for $200 \mathrm{MW}$ of the power after the project failed to meet development milestones. After announcing that the project was officially on hold in 2012, a spokesman for the company stated in 2013 that NRG will maintain the lease as it seeks investors or buyers (Hamilton et al. 2014). Although it is unclear whether the project will be developed or sold, this report considers it to be in the "planning - site control" phase because the lease between NRG and BOEM is still active (see Table 1).

\footnotetext{
${ }^{11}$ The OffshoreMW lease area and DONG Energy's lease area in the Massachusetts WEA are the only existing leasing areas in the United States (thus far) that have competing developers with site control on adjacent offshore wind energy lease areas.
} 


\subsection{U.S. Advanced Technology Demonstrations Projects}

As part of its National Offshore Wind Strategy launched in February 2011, DOE created a new initiative to provide support for regionally diverse ATD projects through collaborative public/private partnerships. The primary goal of these projects is to demonstrate innovative offshore wind systems in U.S. waters in a rapid and responsible manner that have the potential to lower the LCOE. In addition, the program seeks to establish test capabilities in conjunction with commercial developments to support validation of innovative technology, installation methods, and operation and maintenance (O\&M) strategies.

The ATD program will also establish and validate the infrastructure that will be required for efficient offshore wind plant installation and operation to support the development of a domestic offshore wind industry that is adapted to the unique U.S. offshore environment and operating parameters. Finally, the projects are testing the state and federal regulatory processes relevant to offshore wind and will provide evidence that will allow BOEM to improve those processes for future offshore wind project developments in federal waters. DOE expects that evidence from the construction and operation of these projects will address public concerns and investor risk perceptions about offshore wind development in the United States, which will reduce risk and uncertainty and accelerate deployment.

DOE selected three projects in May 2014 to advance to the second phase of the ATD program: Dominion Power's VOWTAP, Fishermen's Atlantic City Windfarm, and Principle Power's WindFloat Pacific. The locations for each project are shown in Figure 10. Each project is eligible to receive up to $\$ 47$ million to complete final design, fabrication, deployment, and demonstration, and all projects are targeted to achieve commercial operation by the end of 2017; however, recent developments suggest that the projects may need more time than originally anticipated. Figure 10 provides the location of each project along with a brief description of the technology that will be demonstrated.

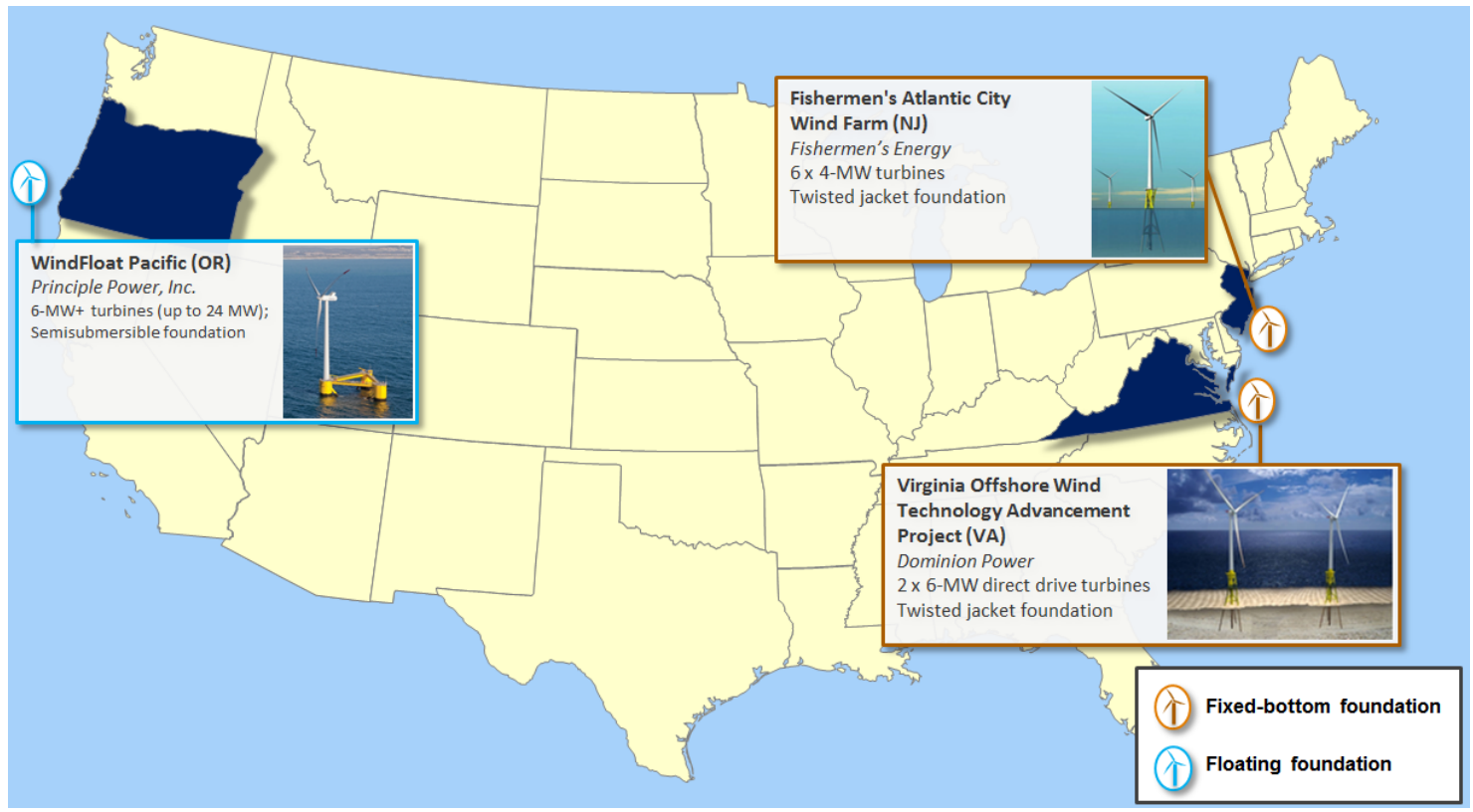

Figure 10. Advanced Technology Demonstration Project awardees. Images courtesy of Principle Power (left) and NREL (top and bottom right) 


\subsubsection{Virginia Offshore Wind Technology Advancement Project}

VOWTAP is a 12-MW pilot project being developed by Dominion Virginia Power on a research lease held by the Virginia Department of Mines, Minerals and Energy. The project is located 42 $\mathrm{km}$ from shore at the eastern edge of Dominion's commercial Virginia lease and includes two Alstom Haliade 150-6MW turbines on inward battered guided structures (IBGSs), a new "twisted-jacket" design developed by Keystone Engineering. Although VOWTAP is a pilot project, Dominion is planning to use the experience gained to inform its future commercial-scale projects, which are located adjacent to it. Developers are planning to orient the two demonstration turbines to study the ability to mitigate wake effects using feed-forward control systems. Although the site conditions do not exceed the turbine system's design strength using traditional offshore structural design standards, developers hope that the project will demonstrate hurricane survival strategies that can inform future installations located in hurricane-prone regions.

Dominion recently announced that the project schedule will be delayed to 2018 after the initial bid price for construction was quoted at around $\$ 400$ million, which was well above the expected cost of $\$ 230$ million. As a result, Dominion and its partners have formed a task force to study ways to reduce project costs, with results expected in early 2016 (Geiger 2015).

\subsubsection{Fishermen's Atlantic City Windfarm}

Fishermen's Atlantic City Windfarm is a 24-MW offshore wind project located $5 \mathrm{~km}$ off the coast of Atlantic City. Fishermen's Energy has obtained all of the permits necessary to proceed with construction and is trying to secure ORECs from the State of New Jersey as one of the final steps toward financial viability. The company plans to install six Siemens 4-MW wind turbines on IBGSs, with final turbine selection pending resolution of the OREC proceedings. The Siemens turbines are fully certified, use modular, three-stage, geared drivetrains, and have been proven to meet operational performance and reliability expectations in European offshore wind farms.

Fishermen's Atlantic City Windfarm's unique proximity to Atlantic City, which hosts over 27 million visitors each year, will provide an opportunity to showcase offshore wind technology to a wide variety and number of people. The array will be oriented close to the prevailing wind direction, creating an opportunity to evaluate the effectiveness of a new plant-level control strategy that would steer wind turbine wakes away from downwind machines to raise the energy capture of the entire array.

In 2010, the state of New Jersey enacted the Offshore Wind Economic Development Act, which called for up to 1,100 MW of offshore wind to be developed in the state and allowed offshore developers to apply for ORECs, which would subsidize the price of offshore wind power. The New Jersey BPU has twice rejected Fishermen Energy's proposal to receive ORECs, citing insufficient public benefit for the project when evaluated at a price approximately $30 \%$ higher than had been proposed by Fishermen's Energy. ${ }^{12}$ The Appellate Division of the Superior Court

\footnotetext{
${ }^{12}$ The New Jersey Board of Public Utilities determined that federal subsidies, such as the Advanced Technology Demonstration grant and Investment Tax Credit, should not be taken into account because they are subject to annual appropriations. Exclusion of these federal subsidies increased the OREC price used in net benefit calculations from the \$199.2/MWh proposed by Fishermen's Atlantic City Windfarm to \$263/MWh.
} 
of New Jersey upheld the decision in May 2015, citing their decision to defer to the board's expertise in the matter. Fishermen's Energy will appeal this decision to the New Jersey State Supreme Court. In parallel, the New Jersey State Senate passed a bill in February 2015 that requires the New Jersey BPU to award ORECs to any project that is a "...nominal $20 \mathrm{MW}$ and no more than $25 \mathrm{MW}$ in nameplate capacity" and located "...offshore of a municipality in which casino gaming is authorized" (NJ Senate Bill 2711). As of August 25, 2015, the bill still needs to pass State Assembly and would then need to be signed by Governor Chris Christie.

\subsubsection{WindFloat Pacific}

WindFloat Pacific is an up-to-25-MW project located $29 \mathrm{~km}$ off the coast of Coos Bay, Oregon, in water depths that average $350 \mathrm{~m}$. The project is expected to consist of an array of 6-8 MW turbines installed on two to three floating WindFloat semisubmersible foundations. The turbines will be installed on the foundations at Astoria, Oregon, using a standard, land-based crane at the port. The integrated units will then be towed 240 miles south to the project site by readily available, inexpensive offshore tugs, where they will be connected to the preinstalled mooring system. Principle Power's WindFloat technology would enable the project to be built without the need for heavy-lift crane operations in the marine environment and using existing U.S. vessel capabilities.

Principle Power, Inc., the project developer, has received a determination of no competitive interest from BOEM for its proposed lease area. As a result, the company has exclusive rights to the site and can proceed with conducting surveys in support of submitting a plan to BOEM for approval. As part of the leasing process, BOEM plans to conduct an environmental assessment, which is expected to be published in 2016. The assessment will evaluate the potential impacts of plan approval and lease issuance. Currently, Principle Power is conducting site investigations to inform the National Environmental Policy Act process. The company is also pursuing power offtake agreements through the recently announced Oregon Offshore Wind Advisory Committee, and, if successful, is poised to deploy the first U.S. offshore wind project in the Pacific Ocean (Principle Power 2015).

\subsubsection{Phase One Advanced Technology Demonstration Projects}

DOE also selected the University of Maine's Aqua Ventas I project and LEEDCo's Icebreaker project from the original group of seven ATD program applicants to receive an additional year of funding at $\$ 3$ million each to continue to advance their project designs. The location of the two projects are shown in Figure 11. These designs will further position the United States to expand commercial-scale offshore wind deployment. 


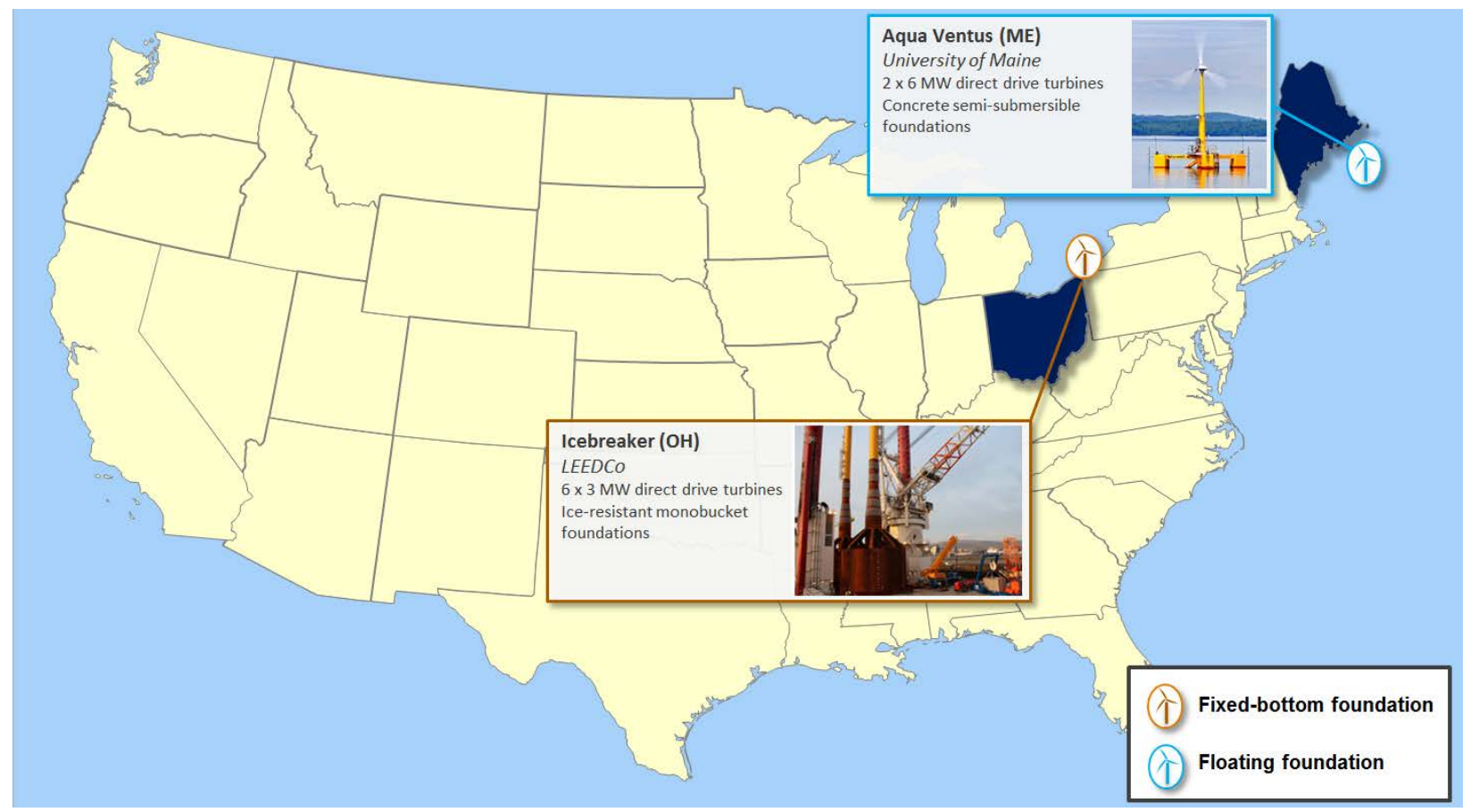

Figure 11. Projects selected to continue technology advancement. Photos courtesy of University of Maine (top) and LEEDCo (bottom)

\subsubsection{Maine Aqua Ventus I}

The DeepCwind Consortium, a public-private partnership led by the University of Maine and involving more than 30 industry partners, is developing the Maine Aqua Ventus I project. The consortium is proposing to deploy two 6-MW wind turbines on VolturnUS floating semisubmersible foundations at a site that is located $3 \mathrm{~km}$ south of Monhegan Island in water that is approximately $95 \mathrm{~m}$ deep. In 2013, DeepCwind deployed a 1:8-scale, grid-connected prototype off the coast of Castine, Maine, to validate design assumptions and collect performance data. Following the successful deployment, in which the platform experienced storms exceeding 50-year extreme design conditions, it was removed in November 2014. DeepCwind plans to use lessons learned from the scaled deployment to optimize the design of the two 6-MW systems that are planned for the Maine Aqua Ventus I project (University of Maine 2015).

In addition to being planned as one of the first floating offshore wind projects in the United States, this project, located in state waters, embodies many unique and innovative features including the use of a concrete hull design and composite towers. Concrete enables much greater local content in the supply chain and may be able to reduce costs relative to steel substructures, although this has yet to be proven. Additionally, composite towers have the potential to deliver the same stiffness properties as steel towers but at a much lower weight, and possibly reducing the required size of the floating platform.

In 2014, the Maine Public Utilities Commission approved a term sheet that would see power generated by the project sold to utilities in Maine. The draft PPA would have a 20-year term and be priced at \$230/MWh with an annual 2.25\% escalation rate (Maine Aqua Ventus 2014). 


\subsubsection{LEEDCo Icebreaker}

LEEDCo plans to install an 18-MW offshore wind plant in Lake Erie, and would be one of the first in the world to be deployed in freshwater, with exposure to surface ice. Known as Icebreaker, this project consists of six 3-MW Siemen's direct-drive wind turbines at a site that is 7 miles north of Cleveland. LEEDCo signed a 50-year submerged land lease with the State of Ohio in 2014 and is pursuing permits and power offtake agreements. In addition, the company has announced strategic partnerships with suppliers including Siemens and Fred. Olsen Windcarrier.

In 2015, LEEDCo announced that Icebreaker will use a monobucket foundation designed by Universal Foundation, which combines a monopile with a suction bucket (Husted 2015). The monobucket foundation combines properties of a monopile and a gravity base to resist overturning. The interface with the seabed is provided by a steel skirt that is approximately $15 \mathrm{~m}$ in diameter and penetrates the seabed to a depth of between 10 and $20 \mathrm{~m}$. This steel skirt is welded to an upper steel tube and transition piece that resembles the above-ground elements of a standard monopile. The monobucket can be installed by applying suction via nozzles located on the skirt, which causes the foundation to sink into the seabed. This installation method eliminates the need for piling, which could lessen environmental impacts relative to conventional monopiles or jackets. In summer 2015, LEEDCo commenced geotechnical investigations at each proposed turbine location to confirm soil properties for the detailed design of the foundations (Funk 2015b). Universal Foundation has been working with LEEDCo and Case Western Reserve University's Civil Engineering Department to design a system capable of withstanding winter ice floes. 


\section{Offshore Wind Technology Trends}

Offshore wind technology is evolving rapidly to meet the requirements of future projects that are generally expected to be built in locations that are deeper and farther from shore. The industry is relying on innovative technology to simultaneously reduce LCOE by cutting the costs of building and operating projects, as well as improving energy production. Although sites that are deeper and/or farther from shore generally increase the costs of building and operating projects, these locations allow developers to access more energetic wind resources, thereby improving power production and minimizing visual and environmental impacts (Hamilton et al. 2014). Furthermore, notable progress is being made on defining precommercial sites in the United States, Europe, and Japan that would accommodate multi-turbine arrays, and could enable larger commercial applications of floating wind turbine technology.

The industry's strong emphasis on lowering costs means that developers and supply chain stakeholders must collaborate to develop and commercialize technology that enables deployment in more challenging locations while simultaneously reducing the LCOE relative to the existing fleet of projects. These dual requirements are inspiring new technology concepts that are being adopted by the industry much more quickly than analysts expected in 2012 when The Crown Estate released the seminal Offshore Wind Cost Reduction Pathways study. In fact, ORE Catapult recently found that the industry is 3 years ahead of the technology acceleration scenario described in that report, which "...envisages a world where new products evolve rapidly, leading to a diverse range of turbines, foundations, cabling, installation methods, and other solutions available in the market" (ORE Catapult 2015; The Crown Estate 2012).

The following section reviews trends in offshore wind site characteristics (e.g., water depth and distance from shore) to provide context for understanding the key drivers behind recent technology innovation. Empirical data from NREL's OWDB provide insight into technology trends through 2020, with a focus on offshore wind turbines, substructures, electric infrastructure, and logistical approaches for construction and maintenance activities. Quantitative analysis of trends within each category is augmented by qualitative discussion that draws on recent developments within the market.

\subsection{Site Characteristics for Global Offshore Wind Projects}

Figure 12 shows the trends of global offshore wind projects as a function of water depth and distance from shore, color-coded by project phase. ${ }^{13}$ The figure includes roughly 5,939 MW of proposed U.S. offshore wind projects that have obtained site control, which appear to be following trends similar to the global data for water depth, although U.S. projects are generally closer to shore. Note that this figure is truncated at a $60 \mathrm{~m}$ water depth. Trends in water depths above $60 \mathrm{~m}$ are presented in Section 4.3 to complement the discussion about floating substructures.

\footnotetext{
${ }^{13}$ This figure does not show global projects that are in the planning phase.
} 


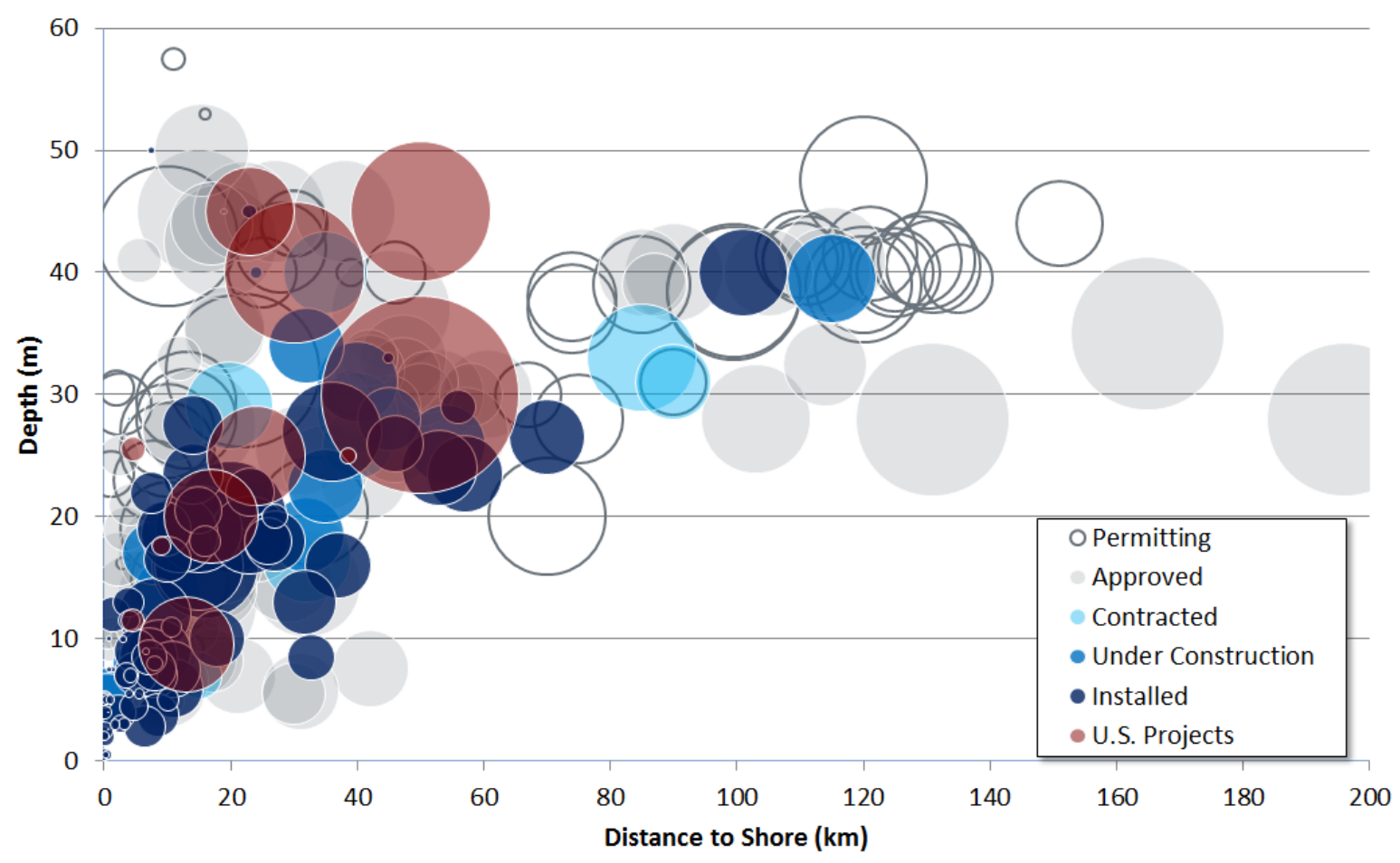

Figure 12. Global offshore wind projects as a function of water depth and distance to shore

Note: Bubble size represents project rated capacity (in MW). The 13 proposed U.S. projects ( $\sim 6 \mathrm{GW}$ ) include all projects that have advanced beyond the site control phase, although Principle Power's WindFloat Pacific project and the University of Maine's Aqua Ventus project, which are located at depths of $435 \mathrm{~m}$ and $90 \mathrm{~m}$, are not shown because of the truncation of the $\mathrm{Y}$-axis.

Figure 12 indicates several trends related to to project status (which can also be interpreted as proxies for time ${ }^{14}$ ), including development into deeper water, increased distance from shore, and larger project sizes. Table 4 provides a more quantitative look at these trends with respect to project development status. It also reveals the percentage of projects that are outside the present envelope of development in each status category as suggested by Figure 12. These envelopes are defined in Table 4 as projects in water depths greater than $40 \mathrm{~m}$, and located farther than $40 \mathrm{~km}$ from shore or larger than $500 \mathrm{MW}$.

Table 4. Summary of Site Characteristics by Project Status

\begin{tabular}{|l|c|c|c|}
\hline & $\begin{array}{c}\text { Water Depth } \\
(\mathbf{> 0} \mathbf{~ m})\end{array}$ & $\begin{array}{c}\text { Distance to Shore } \\
(\mathbf{> 0} \mathbf{~ k m})\end{array}$ & $\begin{array}{c}\text { Project Size } \\
(\mathbf{5 0 0} \mathbf{~ M W})\end{array}$ \\
\hline Installed & $0.2 \%$ & $17.1 \%$ & $19.5 \%$ \\
\hline Under Construction & $0.4 \%$ & $26.5 \%$ & $0.0 \%$ \\
\hline Financial Close & $0.0 \%$ & $29.7 \%$ & $20.1 \%$ \\
\hline Approved & $18.7 \%$ & $46.6 \%$ & $43.0 \%$ \\
\hline Major Permits Submitted & $31.9 \%$ & $58.2 \%$ & $36.1 \%$ \\
\hline U.S. Projects (Site Control) & $24.3 \%$ & $50.5 \%$ & $67.3 \%$ \\
\hline
\end{tabular}

\footnotetext{
${ }^{14}$ A less mature status implies that projects will be installed further into the future.
} 
Table 4 shows that the near-term projects (under construction or financial close) are similar to the operating fleet of projects in terms of depth, distance, and size. The next round of projects are, however, larger and moving into increasingly challenging site conditions. As indicated, about $19 \%$ of projects that have been approved and about $32 \%$ of projects that have submitted major permits are planned to be in depths greater than $40 \mathrm{~m}$. The trend is similar for distance to shore: although roughly $25 \%$ of projects that are under construction or have reached financial close are located less than $40 \mathrm{~km}$ from shore, $47 \%$ of projects that have been approved and $58 \%$ of projects that have submitted major permits are located beyond $40 \mathrm{~km}$. The U.S. projects that have obtained site control seem to have more characteristics in common with future global projects (those that have been approved or submitted major permits) than with operating or nearterm projects (those that have been installed, are under construction, or have reached financial close). It is important to note, however, that some of the WEAs in the United States are large and have a wide range of depths. Therefore, it may be too soon to predict the exact depths and distances for some early-stage U.S. projects.

Wind plants designed for deeper water and greater distances to shore will require innovative technologies and approaches to both enable deployment and simultaneously lower the cost of energy. Water depth is the primary variable influencing the selection and design of the substructure. Deeper water generally increases the height and weight of the substructure. As the substructure gets taller, the stiffness must be maintained to preserve critical system design frequencies. All else unchanged, the designer generally must add more steel, and therefore weight, to the substructure, by increasing its size, footprint, or wall thicknesses. Increasing depth may lead the designer to choose a different substructure type, for example, moving from a monopile to a jacket design.

Distance from shore has several impacts on cost. First, it increases the length of the subsea electrical cables that are required to connect the project to the grid, which increases capital expenditures (CapEx). In some cases, losses caused by standard AC electrical resistance (which increase with distance) are high enough that it may be more cost effective to consider a highvoltage direct current (HVDC) export system configuration; however, that decision depends on a number of factors, such as project size and regulatory environment. ${ }^{15}$ Distance from shore also increases logisitical challenges during construction and operations, thereby increasing both CapEx and operating expenditures (OpEx). Greater distances from port increase the time that it takes to deliver components and personnel to the project, which can raise costs and decrease the effective length of the working day. For projects that are located in high wave climates, an increased distance from shore can also pose additional challenges for accessibility, affecting availability, net energy production, and, ultimately, revenue.

Although the industry is introducing many innovations, the largest driver of cost reduction is expected to come from increasing the rated power and power conversion efficiency of turbines. Fewer larger sized turbines minimize the balance-of-system requirements (i.e., less substructures and other infrastructure required to achieve the same project size). These larger machines do, however, require larger vessels and equipment, as well as enhanced logistical facilities to enable

\footnotetext{
${ }^{15}$ NREL analysis suggests that the breakpoint between high-voltage alternating current and high-voltage direct current technology for an individual 600-MW project is somewhere around $115 \mathrm{~km}$, under current cost levels.
} 
efficient transportation, installation, and operation (Elkington et al. 2013). These increased infrastructure requirements have the potential to slow the adoption of larger turbine sizes in the nascent U.S. market, which currently lacks purpose-built ports and vessels, unless sufficient capabilities are developed. That said, several of the initial demonstration-scale projects in the United States plan to use turbines that are rated at $6 \mathrm{MW}$ or greater.

\subsection{Turbine Technology and Market Trends}

Offshore wind turbines are scaling rapidly; 2014 saw the first deployment of an 8-MW prototype and a number of commercial orders for 6- to 8-MW turbines were executed through June 30, 2015. Larger offshore turbine sizes are enabled because there are fewer logistical limits due to transportation and installation than exist for land-based projects. For example, land-based wind turbine components need to be shipped by road and/or rail, but offshore turbine components can be transported by vessels. Valpy (2014) reports that, all else equal, increasing the size of the turbine from 4 to $8 \mathrm{MW}$ could deliver a $10 \%$ savings in LCOE.

Figure 13 shows global offshore wind turbine trends since the beginning of the industry in 1991 along with the capacity-weighted ${ }^{16}$ average turbine rating (blue), capacity-weighted average rotor diameter (green), and hub height (orange). The forecast through 2020 is based on projects that have announced an agreement or partnership with a turbine OEM, which represents approximately $49 \%$ of the identified project pipeline through $2020(38,397 \mathrm{MW})$.

\footnotetext{
${ }^{16}$ A capacity-weighted average weighs the contribution of given characteristic (e.g., turbine rating) by the associated amount of capacity (MW) based on its percentage contribution to the total capacity installed in a given year.
} 


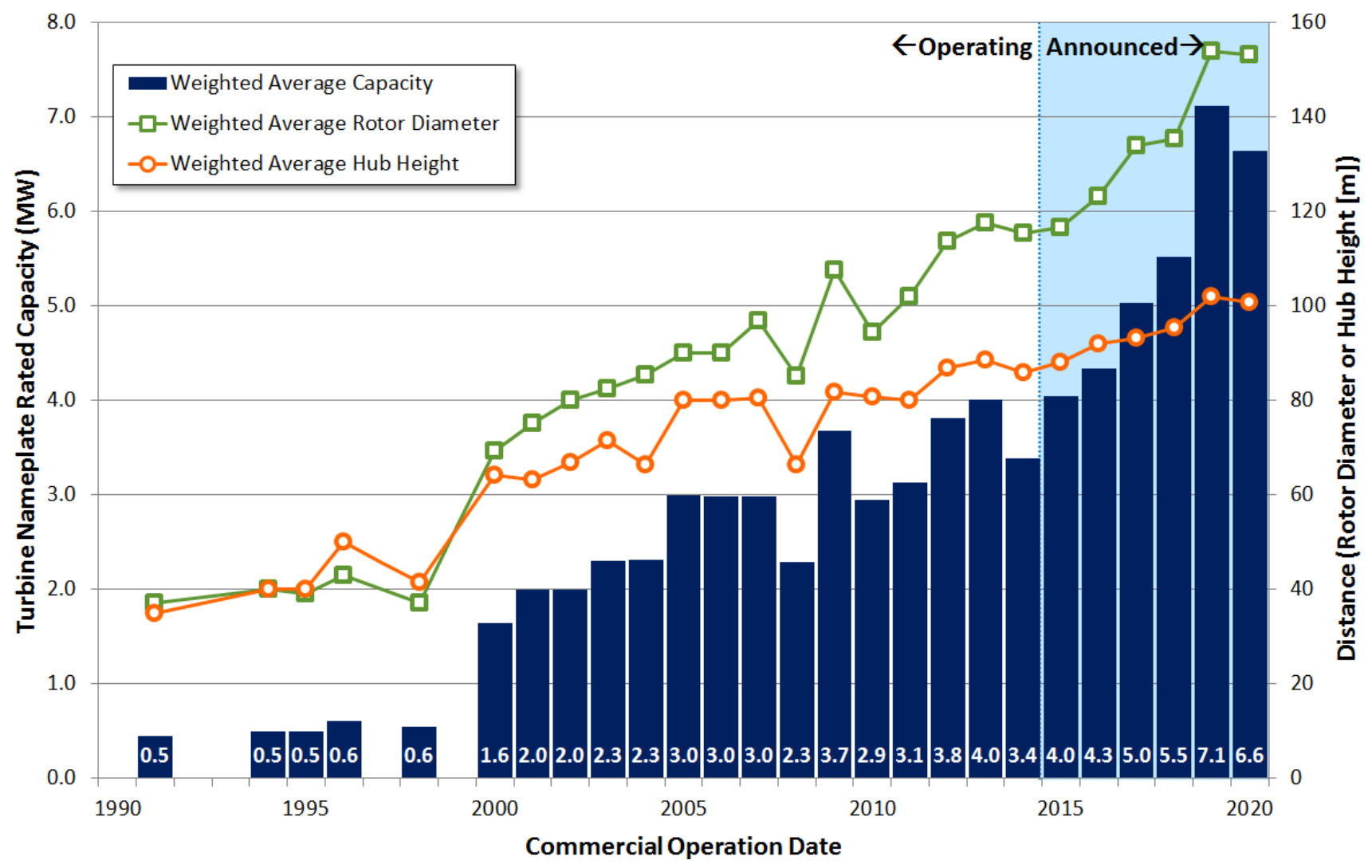

Figure 13. Global turbine capacities, rotor diameters, and hub heights over time

Note: The values for the expected turbine capacities, rotor diameters, and hub heights from 2015 to 2020 are determined from projects that have announced turbine supply agreements. The turbine characteristic weighted average values were calculated by considering each of the project's contribution of annual capacity additions.

Figure 13 shows that the average turbine nameplate capacity of turbines installed in 2014 was 3.4 MW, a 16\% reduction from the 2013 average. The average rotor diameter and hub height decreased slightly to $115 \mathrm{~m}$ ( $2 \%$ reduction) and $85 \mathrm{~m}$ (3\% reduction), respectively. These 2014 averages are, however, anomalous when viewed in the context of long-term industry trends. The data suggest that turbine ratings reached somewhat of a plateau during the period from 2010 to 2015, with the average fluctuating between 3 and $4 \mathrm{MW}$. Over the same time period, the average rotor diameter increased by approximately $20 \%$. An increase in rotor swept area raises the amount of energy that a turbine can extract from the wind at a given site and has contributed to improvements in energy production across the offshore wind industry (see Section 5.3).

Announced turbine supply agreements (TSAs) and partnerships suggest that the average turbine rating will begin to increase again in 2016, reaching an average of between 6 and $8 \mathrm{MW}$ in the $2019 / 2020$ timeframe. At the time of this writing, turbine OEMs are positioned to supply turbines with rated capacity greater than $6 \mathrm{MW}$ for a cumulative order pipeline that exceeds 11,400 MW. Notable developments that OEMs have taken to demonstrate and commercialize turbines include the following:

- Senvion (formerly REpower) was the first manufacturer to deploy 6-MW turbines commercially in 2013 at the 300-MW Thornton Bank II \& III projects in Belgium 
- Siemens recently commissioned the first commercial application of its SWT-6.0-154 turbine on July 1, 2015, at the 210-MW Westernmost Rough wind farm in the United Kingdom; Siemens also introduced a 7-MW machine in 2015 based on the existing 6-MW platform

- Mitsubishi Heavy Industries (MHI) Vestas, a joint venture between MHI and Vestas, signed an agreement with DONG Energy to install the V164 8-MW turbine at the 258-MW Burbo Bank Extension project in the United Kingdom, with an expected COD in 2017 (DNV GL 2015)

- Alstom installed the first Haliade 150-6MW at the Belwind II project in Belgium in 2013 and is slated to supply several demonstration-scale projects in the United States, including the 30MW BIWF and the 12-MW VOWTAP

- Adwen, a joint venture between AREVA and Gamesa, is aiming to test its AD 8-181 MW turbine, with an industry-leading 181-m rotor, in 2015, with commercial production starting in 2018 (Snieckus and Lee 2015)

- Ming Yang installed the first two-bladed 6.5-MW turbine at the Rudong project in China in March 2015.

Although turbine ratings may plateau again in the early 2020s while the industry adapts to 6- to 8-MW turbine sizes (similar to 2010 through 2015 in Figure 13), further long-term growth in turbine size is still likely. Both leading offshore wind turbine OEMs, Siemens and Vestas, have indicated that they will have a 10-MW+ design in the prototype stage by 2020 (Weston 2014a). The Danish Energy Agency recently released a tender that could support the deployment of prototype turbines with up to $50 \mathrm{MW}$ of capacity to help accelerate the commercialization of turbines and other technologies that have the potential to drive cost reduction (Steel 2015). The winners of the tender are expected to be announced in early 2016. There are a number of technical-, infrastructure-, and vessel-related challenges associated with upscaling turbines to reach 10-MW+ ratings; however, the industry has historically taken action in unison to address these concerns as turbines sizes have grown (Smith 2014c).

Traditionally, offshore machines have used high-speed drivetrain architectures with three-stage gearboxes; however, OEMs are now adopting medium-speed (two-stage gearboxes) and directdrive designs for the next generation of turbines. These designs are expected to deliver benefits in terms of weight, reliability, and energy production at larger turbine ratings (Hamilton 2014). Figure 14 shows the trends for both turbine-rated capacity and drivetrain architecture by year of prototype installation (actual or announced). 


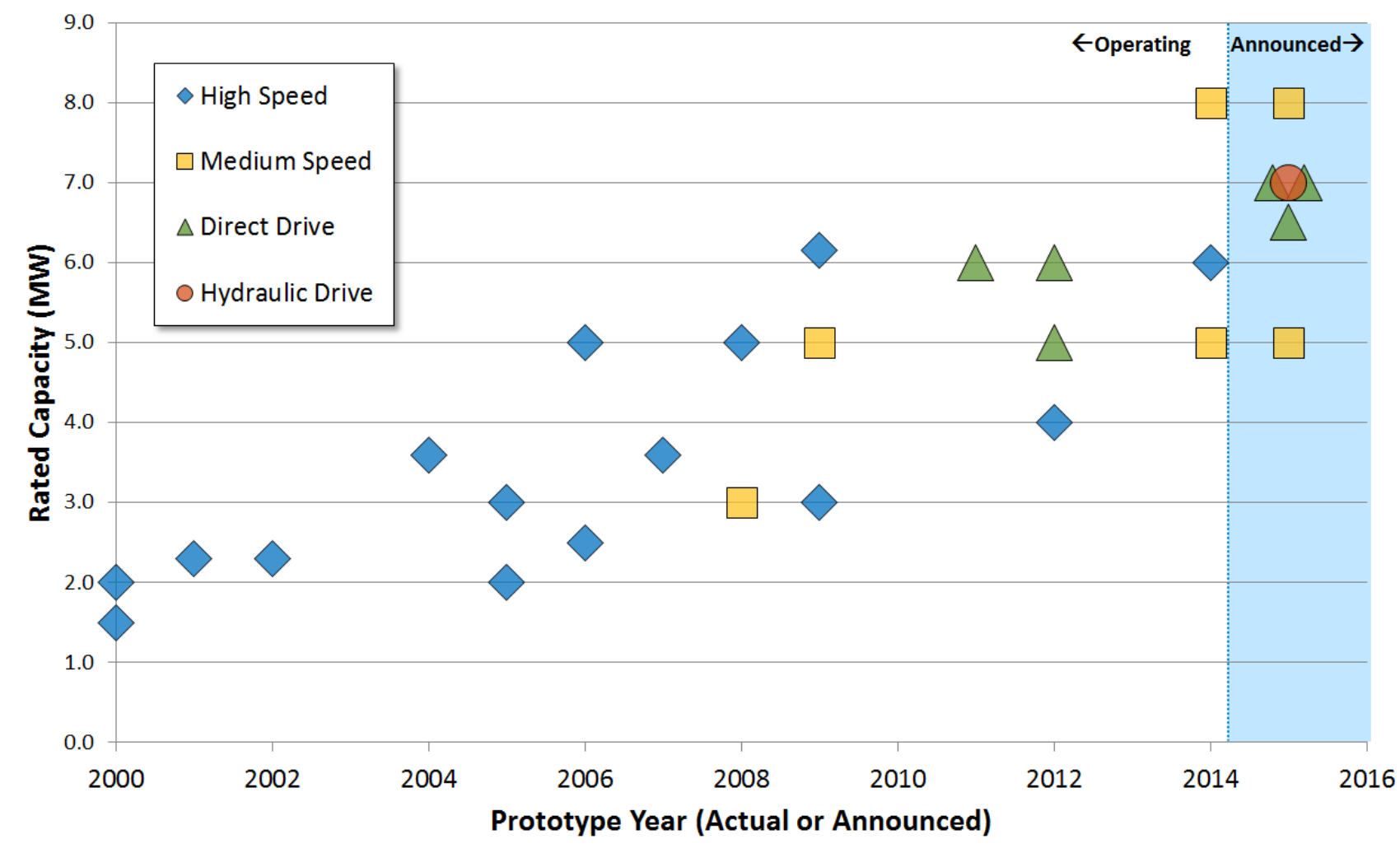

Figure 14. Wind turbine prototype capacity and drivetrain architectures

Note: The data cover only new turbine platforms and do not show incremental changes to a given turbine model. Future expected drivetrain architecture and rated capacity are in the shaded light blue region on the right side. Note that MHI, which installed a 7-MW hydraulic drive turbine at the Fukushima Demo project in 2015, has indicated that, although it will continue to mature its hydraulic drive concept, it will not actively market the turbine because of its joint venture with Vestas.

The trend shows a large and sustained increase in rated turbine capacity from 2000 through 2016, but a more recent shift away from high-speed architectures to alternative designs beginning in 2008. This shift was due in part because of an increasing concern over the reliability of geardriven designs and the additional maintenance costs for offshore service. The emerging diversity in drivetrain design philosophies suggests that there is some disagreement between OEMs about what design will offer the best combination of meeting customer demand specifications and minimizing manufacturing costs (Hamilton 2014). Each architecture offers its own set of advantages; however, there is too little operating experience at this time to determine if a single approach is likely to emerge as the preferred option.

A new trend began in 2014 and 2015 with respect to the formation of OEM consortia, in which there have been several cases of major technology teams consolidating to develop, commercialize, and market offshore wind turbines. This trend may be driven by recognition of the huge investment and commercial risks required to develop the next generation of offshore wind turbines, in which individual orders can total well over $\$ 1$ billion. Warranty obligations can also impose substantial liabilities, if a serial failure affects multiple turbines. Because of this, offshore project investors generally prefer to negotiate major procurement contracts with OEMs that are able to provide strong counterparty guarantees to cover warranty obligations. It is also 
widely recognized that scale might be an important element of OEM strategies to challenge Siemens for market share (Watanabe 2015).

Three main consortia have formed over the past 2 years:

- MHI and Vestas formed a 50/50 joint venture (MHI Vestas Offshore) in March 2014, which takes ownership of the V112 turbine, V164 turbine, and MHI's hydraulic drivetrain technology (Vestas 2013)

- AREVA and Gamesa formed a 50/50 joint venture (Adwen) in March 2015, which takes ownership of the AD 8-181, AD 5-135 (formerly the AREVA M5000), and AD 5-132 (formerly Gamesa G132-5.0) (AREVA 2015)

- General Electric received final approval from the European Union and the U.S. Department of Justice to purchase Alstom's power and grid business in September 2015. This transaction, which is expected to be finalized in the fourth quarter of 2015, is expected to establish a renewable energy joint venture (name yet to be announced) that includes Alstom's offshore wind assets (General Electric 2015).

The global market for offshore wind turbines is expected to become more competitive because of these strong consortia and an increase in the number of proven, financeable turbines that are available to the market.

Figure 15 shows the market share for the top offshore wind OEMs for the operating projects (left pane), as well as market share for the project pipeline through 2020 (right pane). Approximately $49 \%$ of the $38,397-\mathrm{MW}$ pipeline has disclosed a turbine supplier through an unconditional TSA, a conditional TSA, a preferred supplier agreement, or a development partnership agreement. 


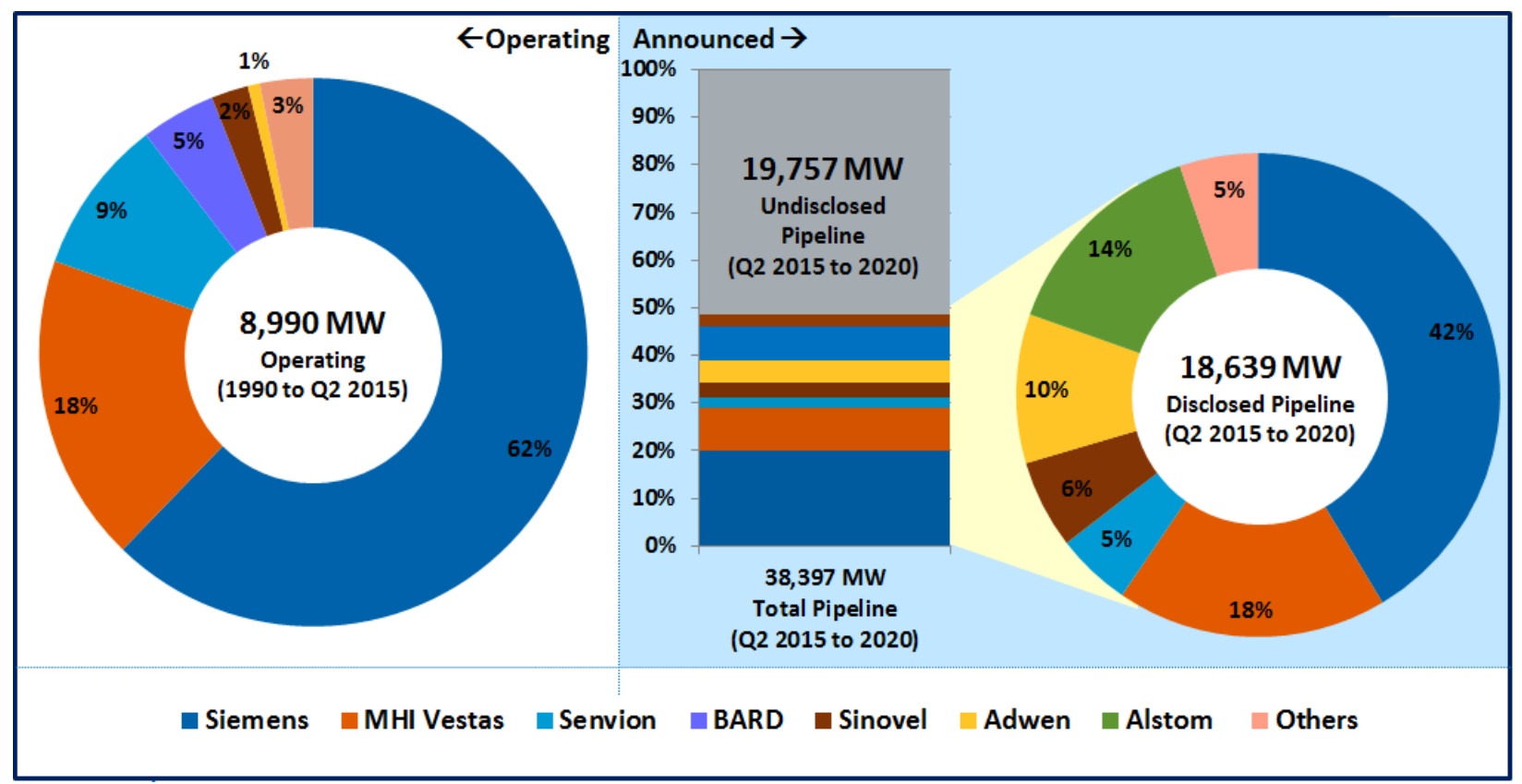

Figure 15. Global market for offshore wind turbine OEMs

Of projects operating by June 30, 2015, (left pane in Figure 15), Siemens has dominated the market with a $62 \%$ share, followed by MHI Vestas at $18 \%$, and Senvion at $9 \%$. BARD, the OEM in fourth place, has since exited the offshore wind business after substantial cost overruns at its 400-MW BARD Offshore I project in Germany. The market share for the pipeline through 2020 (right pane in Figure 15) shows more balance in the market in the future. Siemens is expected to continue to lead but with a reduced market share of $42 \%$, MHI Vestas remains second with an $18 \%$ share, and both Alstom and Adwen are expected to gain traction in the market with 14\% and $10 \%$ shares, respectively. The key drivers behind the more evenly distributed turbine market include:

- A larger annual market size that can support more turbine models

- Increasingly competitive offshore wind turbine designs from a broader array of financially robust OEMs

- A geographic diversification of the offshore wind market, which can allow domestic OEMs to gain commercial orders (for example, Alstom, and to a lesser extent, AREVA, both gained commercial footholds through the two French tenders, which emphasized domestic economic impacts in the evaluation of proposals) (De Clercq 2014).

A more diverse market for turbines is indicative of health in the offshore wind sector. Evidence suggests that increased competition has led to more competitive pricing and rapid technology innovation as OEMs seek to gain and defend market share. This heightened competition should also reduce the chance of repeating the supply chain bottlenecks and disruptions that led to shortages and cost increases for procurement activities that were conducted between 2007 and 2010 (affecting project CapEx for CODs from 2011 to 2015). EC Harris (2012) estimated that increased competition from European OEMs, as well as low-cost Asian suppliers, could reduce TSA prices by $15 \%$. 


\subsection{Substructure Technology and Market Trends}

Substructures for offshore wind projects are evolving to meet the new demands associated with deeper water and larger, heavier turbines. Designers and fabricators are simultaneously innovating to lessen costs by:

- Adopting more efficient geometries that seek to minimize material intensity and increase the ease of fabrication

- Simplifying installation operations, either by decreasing installation time or reducing dependencies on expensive vessels

- Maturing the supply chain by incorporating more efficient, purpose-built equipment and processes into manufacturing facilities and staging ports.

Figure 16 shows three fixed and three floating substructure technology design concepts being considered by the industry. From left to right, the substructures are: monopile, four-legged jacket, IBGS or "twisted jacket," semisubmersible platform, tension-leg platform, and spar buoy. Note that the figure does not show all of the substructure types being considered.

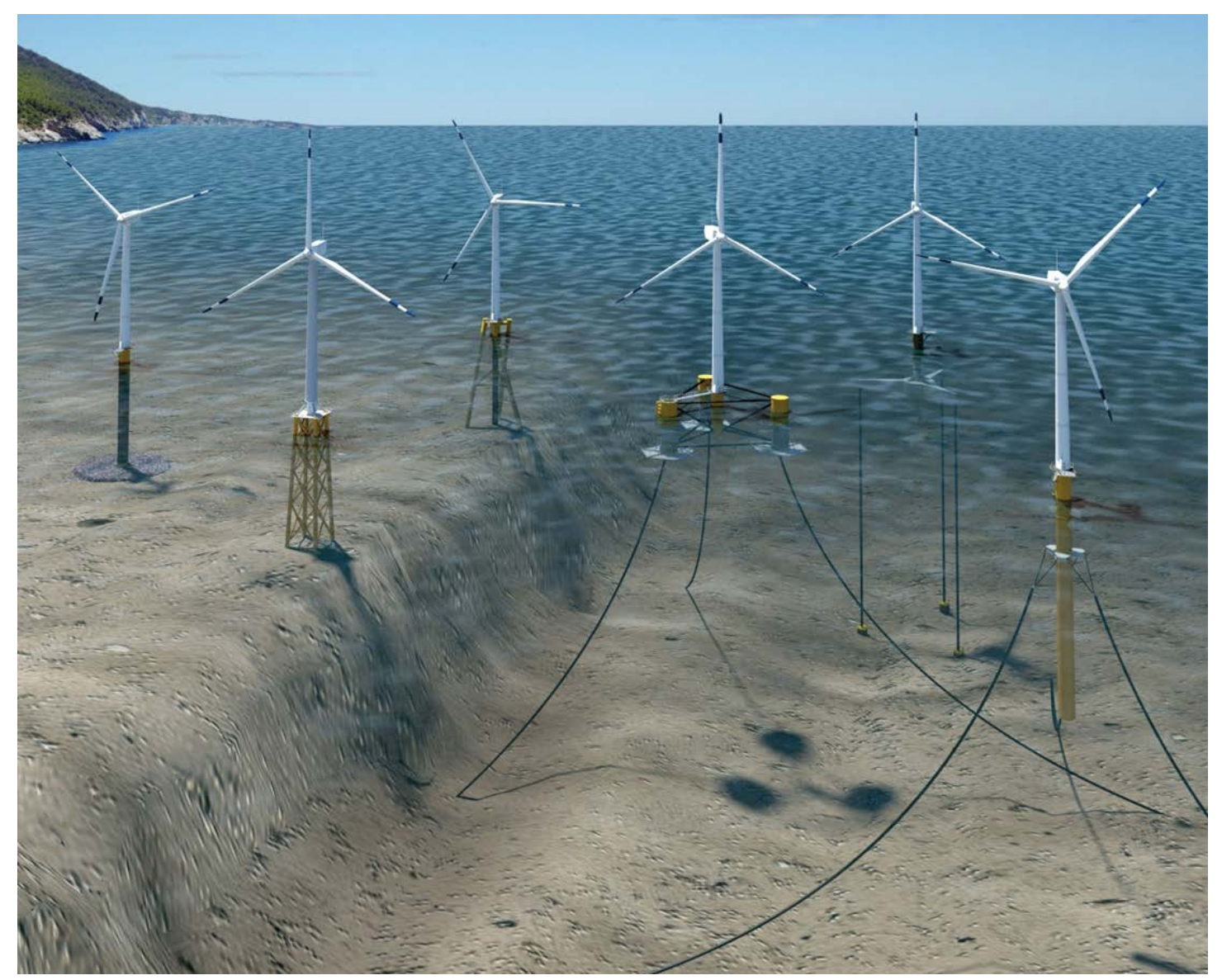

Figure 16. Offshore wind substructure designs for varying water depths. Illustration by Josh Bauer, NREL 
Figure 17 shows the market share for offshore wind substructures for the operating projects and project pipeline through 2020. Approximately $42 \%$ of the $38,397 \mathrm{MW}$ in the development pipeline has disclosed a foundation type, although, in many cases, these announcements may simply be initial proposals and may not reflect a commercial agreement with a supplier.

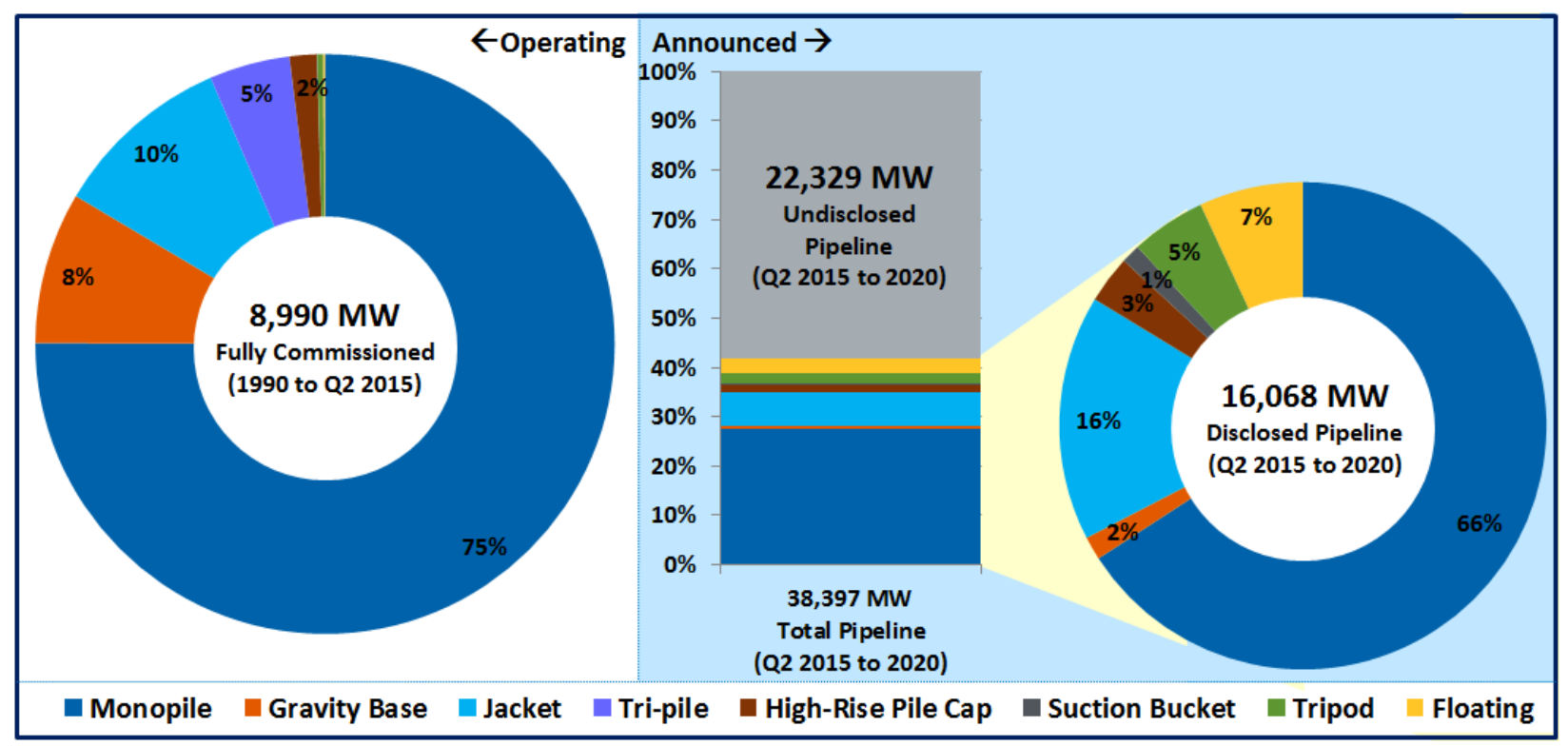

Figure 17. Global offshore wind substructure market share

Figure 17 reveals that monopiles have historically been the dominant substructure, with 6,746 MW installed as of June 30, 2015, or a 75\% market share. Monopiles are followed by jackets (10\% share), gravity bases $(8 \%)$, tri-piles $(5 \%)$, and high-rise pile caps $(2 \%)$.

Looking ahead, monopiles are expected to largely preserve their dominance of the market, representing about $65 \%$ of the disclosed pipeline. Jackets are expected to gain market share, moving up to $16 \%$, reflecting the industry's move to deeper water sites and larger turbine sizes; however, the adoption of jackets has been much slower than expected, largely as a result of the emergence of extra-large monopiles. Floating substructures also seem to be emerging as a large contributor, with a possible $7 \%$ market share based on project announcements. This projection may, however, be artificially high; the majority of this floating capacity (816 MW) is driven by two proposed projects in Hawaii that are currently at a very early stage of development. To date, several precommercial and commercial projects are being proposed, but the timing of deployment remains uncertain for many projects. Gravity-base structures have lost market share-from $8 \%$ to $2 \%$ - to monopiles and jackets; however, advanced gravity base structures, which can be installed without the use of expensive heavy-lift vessels, have the potential to be competitive in the future (Snieckus 2014).

\subsubsection{Fixed-Bottom Substructure Trends}

Monopiles are preferred by the industry for their simplicity both in terms of fabrication and installation. Until recently, many experts thought that monopiles would have limited applicability for waters deeper than $30 \mathrm{~m}$ or turbine sizes greater than $5 \mathrm{MW}$. But new extralarge monopiles, enabled by improved processes that allow for the fabrication and installation of larger-diameter piles and vessels with increased driving capacity, have greatly expanded the 
design envelope. Since 2014, eight projects have selected extra-large monopiles for their substructure with most of them pushing past the previous monopile "envelope of development" for water depth and turbine size. Figure 18 shows the turbine size and water depths for each of these monopile supply contracts plotted with a chart reflecting the common industry viewpoint on the theoretical economic break points between monopiles and jackets in 2012 (BVG Associates 2012). Note that bubble size and label shows the pile diameter for each project (information on pile diameter has not been disclosed for three of the eight projects).

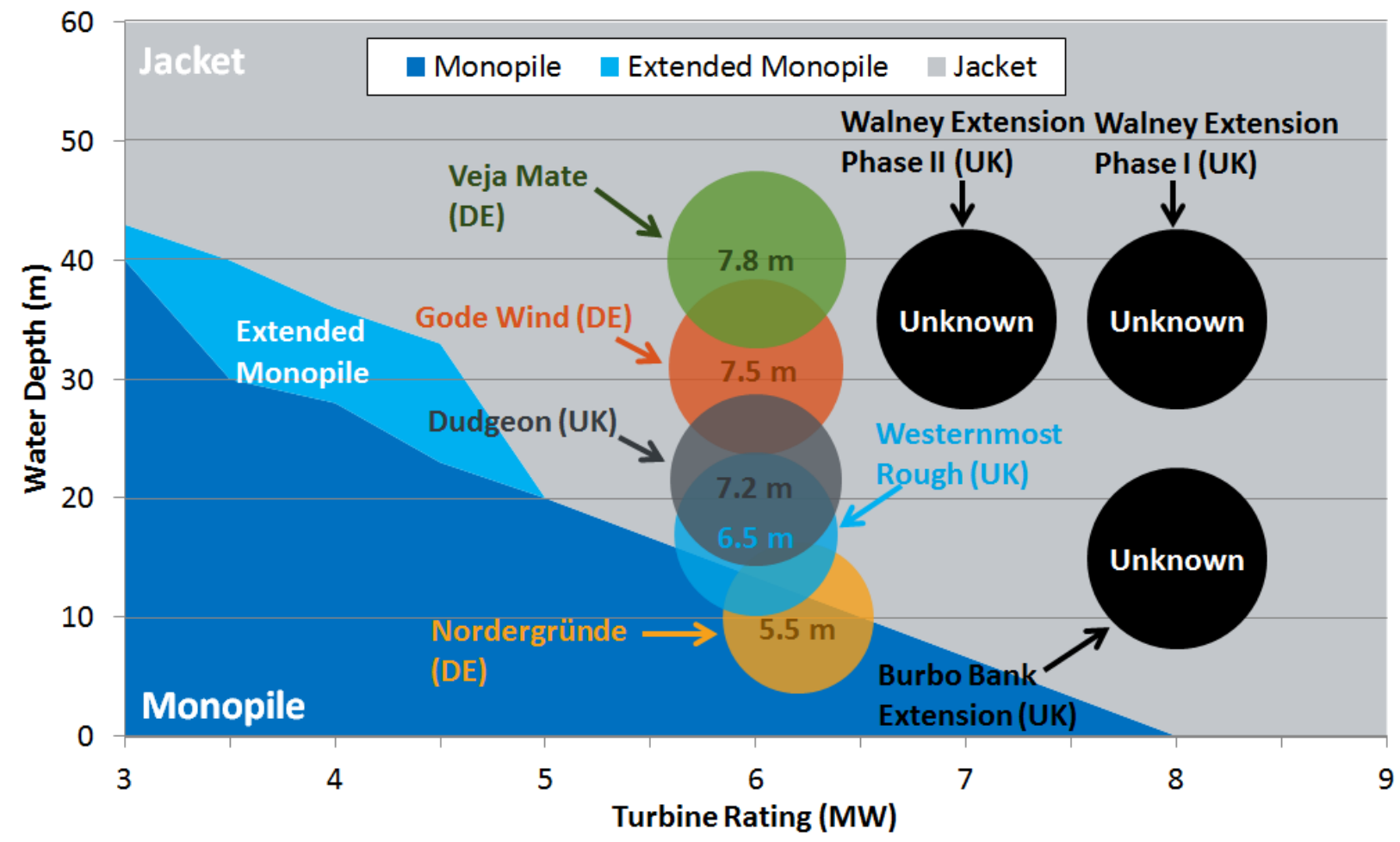

Figure 18. Recent foundation supply contracts showing anticipated foundation types by water depth and turbine size

Source: BVG Associates 2012; DNV GL 2015; NREL

Note: The underlying figure is from data published in the Cost Reduction Pathways Study-Technology Work Stream report (BVG Associates 2012); the foundation contracts update a figure first published in DNV GL (2015). Bubble size shows maximum pile diameter, which is also denoted by the corresponding label.

Figure 18 shows that today's 6- and 8-MW turbines on monopiles in depths greater than $15 \mathrm{~m}$ would exceed practical limits that were thought to exist only a few years ago. Veja Mate, a project using Siemens SWT-6.0-154 turbines in 40-m water depths, is the deepest application of monopile announced to date. The maximum pile diameter at Veja Mate is expected to be $7.8 \mathrm{~m}$ and it is reasonable to assume that projects with 7- and 8-MW turbines in similar water depths will have larger diameters. Ultimately, the industry expects that 10-m monopiles are on the horizon, which, if developed, could further increase the design space for monopile technology, assuming barriers related to supply chain capabilities, transport, and installation can be solved (DNV GL 2015). 
Several joint industry projects are also underway that could lead to an improved understanding of monopile behavior, better design practices, and, ultimately, more cost-effective structures. The Offshore Wind Structural Lifecycle Industry Collaboration is conducting a series of scaled fatigue tests to establish an empirical body of evidence about monopile behavior that will provide insight into how different materials, geometries, and environmental conditions affect performance. The Pile Soil Analysis project is testing monopiles that use thinner steel and are embedded at shallower depths to evaluate the impact of these design changes on performance. The partners tested 28 piles at two land-based sites in the United Kingdom and France that closely replicate surface-soil conditions in the North Sea. Initial test results have been completed and preliminary results show that current design standards are conservative and that there may be opportunities to reduce steel mass of monopile foundations by up to 35\% (Lee 2015a). Both of these joint industry projects aim to inform design standards for future projects and expect that improved knowledge about pile behavior could lead to lighter and more cost-effective substructures (Tavares and Brennan 2015; Weston 2014b).

Additionally, Van Oord, a Dutch offshore contractor, designed monopiles for the 129-MW Eneco's Luchterduinen that eliminates the transition piece, which typically is attached to the monopile with a grouted connection to provide the interface with the turbine tower, by orienting the flange connection to directly withstand blows from the piling hammer. The secondary steel components, including the deck and ladders, are installed after the pile is in place, reducing the overall mass of the substructure by $20 \%-30 \%$ relative to conventional designs (Lacal Arántegui and Serrano González 2015).

The European industry's emphasis on the monopile has led to anticipated stagnation in the jacket market through at least 2016; the only projects to have started construction or reached financial close using jackets are the 30-MW BIWF in the United States and the 350-MW Wikinger project in Germany. The lack of near-term commercial orders for jackets is preventing the industry from industrializing fabrication, which could influence the cost reduction prospects of future sites located in deeper water (DNV GL 2015).

The industry is maturing a number of innovative, fixed-bottom substructures that are expected to be adopted for commercial projects in the near term including:

- The deployment of a 3.6-MW turbine on a three-legged jacket by SPT Offshore and DONG Energy that uses suction buckets, rather than piles, as the interface with the seafloor. SPT will also supply bucket jackets to support the offshore substations at five projects under development by DONG Energy, as well as Statoil's Dudgeon project (DONG Energy 2014; Smith 2014b; Snieckus 2015a). In the United States, a DOEfunded, joint university-industry design and cost analysis shows that suction buckets, with optimized installation procedures and purpose-built port infrastructure, can lead to cost savings for 5- to 10-MW turbines (Kempton et al. 2015).

- The upcoming use of twisted jacket technology by Keystone Engineering for both the 24-MW Fishermen's Atlantic City Windfarm project and the 12-MW VOWTAP in the United States. This technology will provide important opportunities to demonstrate the design for both 4- and 6-MW turbines. 
- A signed agreement by Universal Foundation to use a monobucket foundation, which combines a monopile with a suction bucket, for its 18-MW Icebreaker project in the United States. The company is also reportedly close to a deal to supply the 50-MW Frederikshavn demonstration with foundations, which could be used to support a variety of 6-MW+ turbines (LEEDCo 2015; Snieckus 2015b).

- An advanced gravity base foundation, which can be installed without the use of crane vessels, was installed in 2015 to support a meteorological tower at the Fecamp site in France. EDF and DONG Energy, the project developers, released a request for proposals for the supply and installation of 83 gravity base foundations, which could be installed at the 500-MW Fecamp project, pending successful test results and commercial evaluation (Weston 2015c; Subsea World News 2014).

The BIWF is the first offshore wind project to use a gulf-style jacket, in which piles are driven through the legs of the jacket after it has been placed on the seabed. Although this design has been widely employed in the offshore oil and gas industry, the jackets at the BIWF are the first application of the design for offshore wind turbines. The offshore wind industry has historically used pin-pile designs, in which piles are driven into the seabed and then the jacket placed directly on the piles, or pile sleeve designs, in which piles are driven through sleeves attached to the jacket legs after the jacket has been placed on the seabed.

\subsubsection{Floating Substructure Trends}

Figure 17 shows that floating technology has the potential to make a significant contribution to the global offshore wind market. Demonstration-scale turbines and arrays that have been announced through June 30, 2015, total approximately $218 \mathrm{MW} .{ }^{17}$ Additionally, AW Hawaii has proposed to install commercial-scale floating wind projects, totaling $816 \mathrm{MW}(\sim 70 \%$ of proposed floating capacity) at two locations off the coast of Hawaii by 2020. If successful, this project will be the first commercial deployment of floating offshore wind technology in the world; still, the timing is uncertain given that the developer has not yet obtained site control from BOEM or negotiated a PPA with an off-taking utility.

At the time of this report, five demonstration-scale turbines using floating technology, totaling $15 \mathrm{MW}$, are operating globally. This total includes the July 2015 deployment of a 7-MW turbine at the Fukushima Forward project in Japan, which is the largest turbine installed to date on a floating structure and is representative of the turbine ratings that are expected to be installed in future precommercial and commercial projects. This turbine was deployed on a Mitsubishidesigned, V-shaped steel semisubmersible platform with an eight-line catenary mooring system. Carbon Trust (2015a) recently published the Floating Offshore Wind: Market and Technology Review, which provides an in-depth assessment of floating technology design concepts and project development activity.

\footnotetext{
${ }^{17}$ France launched a tender for floating offshore wind projects on August 5, 2015, that could support four projects with 3 to 6 turbines each, and a minimum turbine rating of 5 MW. De Clercq (2015) reports that the program could support projects with a total capacity between 45 and 100 MW by 2020, which would be in addition to the 1,140 MW identified in the pipeline.
} 
These initial installations have successfully demonstrated the feasibility of floating technology. The likely next step for the industry is to deploy precommercial arrays of turbines, with 6-MW+ turbines numbering between 2 and 10 units to demonstrate the progress towards cost reduction (from single turbine demonstration project levels) and increase investor confidence in the performance and reliability of the technologies. Floating wind turbines have gained substantial interest in countries that have deep water offshore wind resources, including Norway, Portugal, Japan, China, the United States, United Kingdom, Spain, Italy, and Korea. Appendix E provides a summary of active floating technology demonstration projects that NREL has identified globally.

Figure 19 shows the $218 \mathrm{MW}$ of announced demonstration-scale projects, as well as the twoproject commercial-scale proposal from AW Hawaii, which comprise the floating offshore wind development pipeline through 2020. The figure shows water depth, COD, and project rated capacity. Figure 19 shows the hypothesized design space for fixed-bottom wind technology (detailed in Figure 12) for comparative purposes (Musial and Ram 2010).

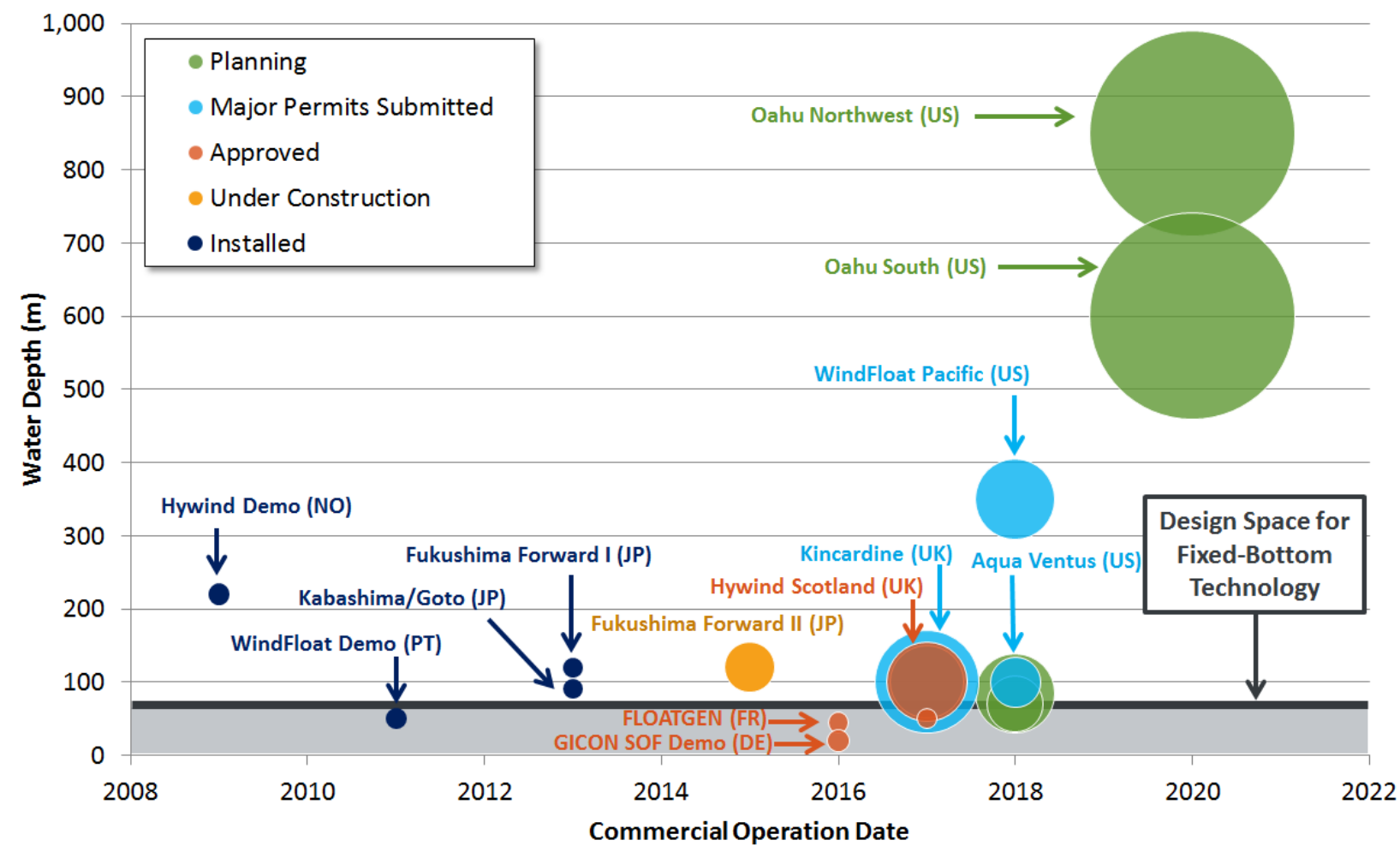

Figure 19. Global pipeline of operating and proposed floating offshore wind projects

Note: Bubble size represents project rated capacity (in MW).

Figure 19 shows that floating offshore wind projects are expected to increase both in water depth and rated size as the industry gains experience through 2020. It is evident that there are three distinct phases of maturity: 1) initial, proof-of-concept demonstration (small projects), 2) precommercial deployment (medium-sized projects), and 3) commercial-scale deployment (large projects). Although the experience gained by the early adopters (i.e., Statoil, Principle Power, and the Fukushima consortium) is expected to ease the path for new technology concepts, it is expected that each new technology will need to undergo a similar, single-turbine test and 
validation program to gain the investor confidence required to enable commercial-scale deployment.

The floating projects will likely break from the historical experience of fixed-bottom turbines (Figure 12), in which water depth was increased incrementally. Floating systems are moored to the seabed, and so the cost sensitivity of increasing water depth will be much lower than for fixed-bottom technology. This characteristic suggests that floating technology will be highly adaptable for a wide range of water depths up to at least 1,000 m (Musial and Ram 2010). Although most projects are proposed in water depths greater than $50 \mathrm{~m}$, GICON is planning on installing its prototype tension-leg platform design in water depths of just $20 \mathrm{~m}$ and believes that the design could be competitive with monopiles. In addition to being the shallowest floating turbine installed to date, this prototype, which is scheduled for installation in 2016, could also be the first wind turbine installed on a tension-leg platform and the first floating turbine in Germany (Weston 2014c).

With less dependency on depth and, possibly, lower installation costs, this type of technology has the potential to open new markets to offshore wind development that were previously inaccessible with fixed-bottom technology. That said, floating structures are generally heavier than fixed-bottom structures, and the water depth at which floating structures will become more economic than fixed structures has not yet been identified.

\subsection{Electrical Infrastructure Technology and Market Trends}

Electrical infrastructure typically has three components. The array system collects power from the transformers of individual wind turbines and delivers it to the offshore substation transformer via a grid of submarine cables (typical rating of $33 \mathrm{kV}$ ). The export system usually includes a substation that transforms array voltage up to the export voltage (typical rating of 132 and 220 $\mathrm{kV}$ ), subsea cables that transmit electricity to shore, and a land-based transmission infrastructure, including transmission lines and substation upgrades or new construction that are required to connect to the existing power grid on land. In 2014 and 2015, three important developments in electrical infrastructure emerged, as described here.

\subsubsection{Array Cable System Trends}

Array cable systems for commercial projects are typically rated at $34 \mathrm{kV}$ and connected radially to the substation. The rated capacity of cables at this voltage is approximately $36 \mathrm{MW}$ for a single cable connected to the substation, which has worked well with turbines rated below 6 MW. Moving to larger turbine sizes limits the number of turbines that can be connected to the substation with a single cable, which, all else equal, will increase the length of array cables required for a given project.

Increasing the array system voltage to $\sim 66 \mathrm{kV}$ would enable more efficient array cable layouts for projects using larger turbine ratings and reduce CapEx. Other benefits of higher array voltage would be fewer electrical losses (up to $75 \%$ ) within the array cable system, decreased substation transformer weight and number of substations, as well as the ability to adopt more redundant array cable layouts (e.g., ring configurations) to increase reliability. Progress towards higher voltage array systems has been slower than anticipated (DNV GL 2015). Two projects in the United Kingdom, the 710-MW East Anglia ONE Project and the 448-MW Neart Na Gaoithe, recently released a supply chain report that highlighted plans to adopt higher voltage array 
cables, pending the success of qualification studies sponsored by the Carbon Trust's Offshore Wind Accelerator (Vattenfall and ScottishPower Renewables 2014; Mainstream Renewable Power 2014). ${ }^{18}$

\subsubsection{Export System Trends}

The trend towards siting projects farther from shore is increasing the length of export cables and driving offshore wind project developers to adopt system designs based on higher voltages. These changes signify that export system costs are contributing more to overall life cycle costs, and are increasingly becoming a focal point for cost reduction efforts. ${ }^{19}$

In 2015, Siemens unveiled its high-voltage alternating current (HVAC) offshore transmission module (OTM), which packages the electrical conversion equipment typically found on standalone offshore substations into smaller, lighter units that can be installed directly on (slightly modified) turbine substructures. Each OTM weighs 630 metric tonnes (mT), is approximately 10 $\mathrm{m}$ high by $30 \mathrm{~m}$ long, and can accommodate $250 \mathrm{MW}$ of power. The compact size and light weight means that the units can be installed by the jack-up crane vessel used for turbine installation, removing dependencies on expensive heavy-lift vessels that can cost between $\$ 300,000$ and $\$ 850,000$ per day. Siemens anticipates that the OTM can reduce substation CapEx, including procurement and installation costs, by up to 40\% (Snieckus 2015c). The 448-MW Neart na Gaoithe in the United Kingdom announced that it will adopt this technology (Mainstream Renewable Power 2014).

For projects that are located far from shore (breakpoint between 90 and $120 \mathrm{~km}$ ), conventional HVAC systems can be prohibitively expensive when evaluated in terms of CapEx and potential revenue losses. In these situations, developers or Transmission System Operators (TSOs) have opted for HVDC solutions. TenneT, a German TSO, has chosen HVDC technology to connect several German projects to the grid, totaling $6,840 \mathrm{MW}$ by 2019 , because they are located far from shore and grouped into 600- to 1,000-MW clusters (TenneT 2015). Several of these connections have been completed; however, technical and logistical challenges led to significant schedule delays and cost overruns. Major contractors, including Siemens and ABB, have announced cost overruns, which total over $€ 1$ billion ( $\$ 1.3$ billion) when combined, and expressed that they will be taking a more cautious approach to future bids from pricing and risk acceptance perspectives (Smith 2014c; Webb and De Beaupuy 2014). ${ }^{20}$

These developments introduce uncertainty into how future HVDC contracts will be priced; yet, available evidence suggests that prices will likely increase. Energinet.dk, who will connect the 600-MW Krieger's Flak III Zone to the Danish grid, selected an HVAC configuration, despite initial plans to use an HVDC system; tender results suggested a cost level for the HVDC system

\footnotetext{
${ }^{18}$ Carbon Trust, as part of its Offshore Wind Accelerator, awarded contracts to three cable manufacturers (Prysmian, Nexans, and JDR) to support design, manufacture, and qualification tests for $66-\mathrm{kV}$ array cable designs (Carbon Trust 2014).

${ }^{19}$ For developers who are responsible for offshore grid connection. The export system is less of a focus in markets in which grid connection responsibility lies with the Transmission System Operator.

${ }^{20}$ For example, ABB indicated that it will no longer provide a wrap on converter system contracts, thereby guaranteeing a fixed-price value for executions.
} 
that was higher than budgeted (Windpower Offshore 2014). In response to these challenges, developers and TSOs are considering alternatives, including:

- An HVAC solution designed by DONG Energy and Ramboll for the 1,200-MW Horsea Project, which is located $120 \mathrm{~km}$ from the point of cable landfall, involves the installation of reactive power compensation substations midway along the export cable to counteract capacitance, ${ }^{21}$ thereby reducing the transmission losses that would otherwise be expected (Ramboll 2015)

- An upcoming (2015) OTM design by Siemens for HVDC converter platforms that could help reduce the cost of HVDC systems (Radowitz 2015).

\subsection{Vessel and Logistical Trends}

As stated earlier, existing offshore wind projects are expected to move to sites that are farther from shore, in deeper water, and subject to more severe metocean conditions. Simultaneously, there is a trend towards larger turbine sizes, which are characterized by bigger, heavier components and higher hub heights. As a result of this growth in size and weight, new logistical challenges related to construction and maintenance activities have surfaced. The U.S. industry has its own particular set of challenges, introduced by Jones Act requirements, ${ }^{22}$ which is leading developers to modify installation strategies to match the capabilities of the U.S. vessel fleet. These strategies, which are generally less efficient than those that can be achieved with the purpose-built fleet of vessels in Europe, are likely to result in a cost premium for the initial U.S. projects (Snieckus 2015a).

\subsubsection{Construction Vessels and Logistics Trends}

Douglas Westwood (2013) discusses trends in installation vessels that are generally increasing in size to handle the bigger components associated with larger turbines. Yet, the market for jack-up vessels is much more balanced because of the commissioning of several new vessels between 2013 and 2014. Despite this progress, there are very few vessels that can handle the largest turbines on the market, which are expected to have hub heights ranging from 105 to $115 \mathrm{~m}$. The shortage could be particularly apparent when turbines are located in deepwater sites; the maximum effective crane hook height is a function of water depth, jack-up leg length, soil properties (which determines leg penetration), and crane height. The industry does have 2-3 years of lead time before 6- to 8-MW turbines become the industry standard (likely in 20172019), so it is uncertain whether this concern will manifest into an actual shortage.

Blade installation operations have historically been sensitive to weather limits, specifically wind speed. Installation contractors are reporting significant progress in the growing range of weather conditions in which blades can be installed. In 2015, High Wind NV (2015) introduced the Boom Lock, which can be fitted to cranes to provide stability for lifting operation in winds averaging 15 meters per second (m/s). Siemens (2014) has developed a new lifting frame for its

\footnotetext{
${ }^{21}$ Electrical capacitance increases linearly with voltage and distance and increases the charging current required to energize cables, thereby reducing the cable's capacity to transfer power (Daniel et al. 2014)

${ }^{22}$ The Jones Act (also known as the Merchant Marine Act of 1920) prohibits the transfer of merchandise between "points in the U.S." unless the owner and crew of the vessel are "American," as certified by the Secretary of Transportation. The Secretary may, however, choose to grant an exemption if no suitable American vessels exist (Hamilton et al. 2014).
} 
75-m blades that allow for operation in average wind speeds of up to $14 \mathrm{~m} / \mathrm{s}$ and can automatically connect and disconnect from the blade, removing the need for manual intervention. By increasing operability from the estimated $8 \mathrm{~m} / \mathrm{s}$ to $12 \mathrm{~m} / \mathrm{s}$ limit in 2012, these innovations could reduce downtime related to weather, thereby reducing project schedule and cost as well as construction risk.

Although purpose-built substructure installation vessels have been discussed for many years, the industry continues to rely on a combination of purpose-built turbine installation vessels and general-purpose heavy-lift vessels (sourced from the oil and gas or marine construction industries). The recent collapse in global crude oil prices has triggered a decline in offshore oil and gas exploration and construction activities. This decline has released a key source of demand in the marine contractor market and led to reduced day rates (Offshore Aberdeen 2015).

Buchanan (2015) reports that day rates for offshore service vessels, which are a decent proxy for vessel day rates across the offshore construction industry, have fallen by as much as $30 \%$ in the Gulf of Mexico. This weak vessel demand suggests that the benefits of purpose-built substructure installation vessels are probably less than what was anticipated a few years ago.

Deepwater Wind has begun installing jackets at its 30-MW BIWF using a Jones-Act-compliant marine operations philosophy that relies on American vessels. A joint venture between Weeks Marine and Manson Construction, the foundation installation contractor for the project, is relying on three floating crane barges to perform the installation operations for each jacket, which includes the following steps:

1. The Weeks 533, which has a maximum crane capacity of $454 \mathrm{mT}$, will lift the 400 -mT jackets from a transportation barge and place them on the seabed. It will then hammer the first set of piles through the legs to provide the initial connection between the jacket and the seabed.

2. The Weeks 526 will move into position to drive the remaining sets of piles to an embedment depth of $\sim 60 \mathrm{~m}$, and fully secure the jacket.

3. Once the pile-driving operations are complete, the Weeks 533 will return to the location and place the 400-mT deck sections onto the jacket.

4. The Weeks 571 will complete welding, grouting, and painting operations, which will mark the completion of the jacket installation (Kuffner 2015a).

This operations process uses more vessels to complete jacket installation than most European projects, which have generally adopted one of two approaches. In a pin-pile design, the piles are driven through a piling template that is placed on the seafloor. The jacket is later placed on to the preinstalled piles by a separate vessel and grouted into place. In a post-pile design, the installation vessel places the jacket on the seafloor, drives piles through the pile skirt, and grouts the interface between the pile and the skirt. Pile driving is typically conducted below the water line for both pin- and post-pile designs, but pile driving in the BIWF installation method occurs above the water line.

European installation vessels have crane capacities that typically range between $800 \mathrm{mT}$ and $1,500 \mathrm{mT}$, or roughly double to triple the capacity of the Weeks 533. This additional crane capacity means that the entire jacket, including the main lattice, transition piece, deck, and 
outfitting steel can be lifted in one piece, enabling integration at the fabrication yard rather than at sea. All else constant, less time at sea generally results in lower costs because: 1) operations can generally be performed more efficiently on land, 2) there is less downtime related to unfavorable weather conditions, and 3) expensive vessels are not needed to support the operation. It is also more difficult to achieve the necessary welding quality in the offshore environment and can change the jacket design philosophy, which can potentially add weight relative to a single-piece design. The actual price for installation operations, however, depends on more than duration (e.g., vessel day rate also contributes); it is unknown how the prices for installation of the BIWF compare to European pricing data because this information has not been disclosed.

Although the installation process for the BIWF jacket may be less efficient from a timing perspective than the methods applied in Europe, it does offer several advantages. First, the process reduces underwater noise emissions relative to other jacket designs by driving piles above the water line. Minimizing noise emissions is crucial for the protection of endangered marine mammals and, in Europe, has been achieved through the use of expensive ancillary devices, such as bubble curtains, which minimize sound wave propagation. Second, it avoids having to apply grout to connect critical interfaces underwater (i.e., between the jacket and piles). Third, piling through the jacket legs avoids the need to design and fabricate a custom piling template (required for pin-pile designs) or to add pile skirt sleeves (required for post-pile designs).

The fact that a U.S. contractor is performing the operations is crucial to the future development of the domestic offshore wind market given the restrictions imposed by the Jones Act. Weeks Marine will undoubtedly gain enormous insight from its experience working on the BIWF, which will position the company to better support domestic commercial-scale deployments. This operational knowledge is expected to translate into a better understanding of how to effectively utilize existing assets and could help inform U.S. vessel requirements to make the installation

process more efficient. Finally, successful implementation will demonstrate to investors that U.S. marine contractors have the ability to deliver needed services, addressing a key risk perception about the industry.

\subsubsection{Maintenance Vessels and Logistics Trends}

OpEx are expected to vary considerably between offshore wind plant locations. From previous experience, (Maples et al. 2013; Jacquemin 2011; Pieterman 2011) the two largest locational drivers of O\&M cost differences between offshore wind projects are the distance between the project and maintenance facilities (e.g., O\&M port and/or inshore assembly area) and the prevailing metocean climate at the project site. The siting of offshore wind projects in locations that are farther from shore and in more demanding metocean conditions has amplified the challenges of safely delivering technicians and components to the project site. These accessibility issues, which affect the operator's ability to conduct scheduled and unscheduled maintenance activities, can have a large impact on both OpEx and turbine availability (which affects energy production). Operators are addressing these challenges by rapidly incorporating next-generation O\&M vessels, many of which have been developed with assistance from the Carbon Trust's Access Competition, into their logistical strategies (Carbon Trust 2015b). 
Greater distance from shore affects the travel time between the port and the wind project, reducing the effective length of the working day. As a result, increased distance from shore would either increase the duration of operations or require additional personnel to keep the duration constant. The primary impact of metocean conditions is on accessibility and, therefore, turbine downtime and equipment utilization rates. Examples of methods that operators are using to address these challenges and optimize O\&M strategies are as follows. ${ }^{23}$

For projects that are a medium distance from port (nominally between $40 \mathrm{~km}$ and $70 \mathrm{~km}$ ), operators are testing vessels known as surface effect ships, such as the UMoe Wave Craft, which increases vessel speed from 20 to 35 knots and increases the limit on technician transfers from $1.5 \mathrm{~m}$ significant wave height (Hs) to $2.5 \mathrm{~m} \mathrm{Hs}$. DONG Energy has chartered for testing at Borkum Riffgrund 1, located 54 km from its O\&M base in Norddeich (DONG Energy 2014).

For projects that are a greater distance from port (nominally beyond $70 \mathrm{~km}$ ), operators are beginning to use service operations vessels from designers such as Esvagt and Ulstein Verft. These vessels are designed to stay on-site for extended deployments, with endurance generally exceeding 1 month. These crafts are outfitted with the capability to launch small service vessels and typically have motion-compensated gangways to allow for technician transfers in harsh weather. Siemens is deploying service operations vessels at four projects and estimates that its deployment of one such vessel at Westernmost Rough will cut weather downtime from the current levels of $40 \%-45 \%$ down to levels of $10 \%-15 \%$ (Snieckus $2015 \mathrm{c}$ ).

\footnotetext{
${ }^{23}$ An optimized O\&M strategy is one that simultaneously minimizes direct OpEx while maximizing the revenue that the project can generate through power sales (maximizing availability).
} 


\section{Cost and Performance Trends}

The most pressing challenge that the U.S. offshore wind industry faces is the current high cost of offshore wind generation and the related lack of available PPAs and/or state and federal policies to support the development of the industry. NREL estimates that a hypothetical 500-MW offshore wind project built in the United States in 2013 at a typical site on the Northeast Atlantic OCS would have an $\mathrm{LCOE}^{24}$ of approximately \$215/MWh (Moné et al. 2015). This cost level suggests that offshore wind developers would require PPA prices that exceed the current wholesale prices to make projects economically feasible.

Global offshore wind stakeholders, including developers, OEMs, contractors, policymakers, regulators, and $\mathrm{R} \& \mathrm{D}$ funding bodies, all recognize the need for cost reduction to minimize reliance on public subsidies and sustain the long-term growth of the offshore wind industry. This emphasis on cost reduction is driving efforts to optimize technology and processes throughout the entire project life cycle, spanning development, construction, and operations. Recent empirical data from government surveys and competitive tenders, which are discussed in detail later in this section, suggest that LCOE is likely to decrease through at least 2020.

It is clear that the U.S. market will leverage European technology and experience, developed over more than 20 years, which suggests that the cost structure will likely be similar between the two markets and, further, that cost reductions achieved in Europe should translate to the U.S. market. Still, there are several key differences between the markets that contribute to the uncertainty about cost levels for the initial set of commercial projects in the United States. These factors include currency exchange rates, infrastructure improvements, supply chain maturity, vessel availability, workforce readiness, and physical characteristics of the offshore wind siting environment. Further, the cost level could be influenced by U.S.-specific political considerations, including regulatory structure, the tax code, and the design of incentive programs.

This section provides insight into the cost and performance trends for offshore wind projects using available empirical data about CapEx, OpEx, energy production, and finance. It also presents a case study on the recent competitive auction results in the British and Danish markets to illustrate how cost levels may be declining. NREL's forthcoming 2014 Cost of Wind Energy Review (an update to the 2013 Cost of Wind Energy Review cited above) will use the market statistics described in this chapter to calculate the estimated LCOE for a hypothetical 500-MW offshore wind project in the United States (Moné et al. forthcoming).

\subsection{Capital Expenditures}

CapEx is the single largest contributor to the life cycle costs of offshore wind plants and includes all expenditures incurred prior to the COD. Figure 20 shows the reported CapEx over time for operational projects as well as those in various stages of the near-term project pipeline. Each

\footnotetext{
${ }^{24}$ The levelized cost of energy (LCOE) is a metric that is widely used by analysts to conduct comparisons of generating costs between technologies and international markets. It is best summarized as the net present value of costs divided by the net present value of energy production. The metric excludes any subsidies (e.g., renewable energy credits) or revenue streams (e.g., capacity payments) that may be available to the project and is generally measured at the point of interconnection to the existing electricity grid. LCOE cannot be directly compared to power purchase agreement price, which generally accounts for these parameters.
} 
bubble represents the cost estimate for a single project and bubble size represents the project rated capacity. The orange line shows the capacity-weighted average CapEx and provides an indication of the overall trend from 1990 to 2020.

Costs have been reported for 8,409 MW of global offshore wind projects, or about $94 \%$ of the total installed capacity as of June 30, 2015. Figure 20 also includes the announced costs for 15 projects $(3,094 \mathrm{MW})$ that have started construction, seven projects $(2,625 \mathrm{MW})$ that have closed contracts, 17 projects $(6,020 \mathrm{MW})$ that have received regulatory approval, two projects (978 MW) that are in the permitting process, and one project $(700 \mathrm{MW})$ that is still in the planning phase. Generally, greater confidence can be placed in cost estimates that are in more mature stages of the project life cycle (i.e., costs for a project that has reached FID is typically more certain than for a project that has not yet received permits); however, preliminary estimates do provide insight into developer expectations about cost trends.

Individual CapEx data points should be viewed with a degree of skepticism because: 1) they are normally self-reported by developers and are difficult to verify independently, 2) there is limited transparency into the financial impact of cost overruns, and 3) it is often unclear whether the reported CapEx is comprehensive and fully captures the cost to install the project and connect it to the grid. ${ }^{25}$ When viewed together, though, these data provide insight into the long-term cost trends.

\footnotetext{
${ }^{25}$ For example, it is unclear if the announced capital expenditure values include soft costs such as construction financing, insurance, or fees.
} 


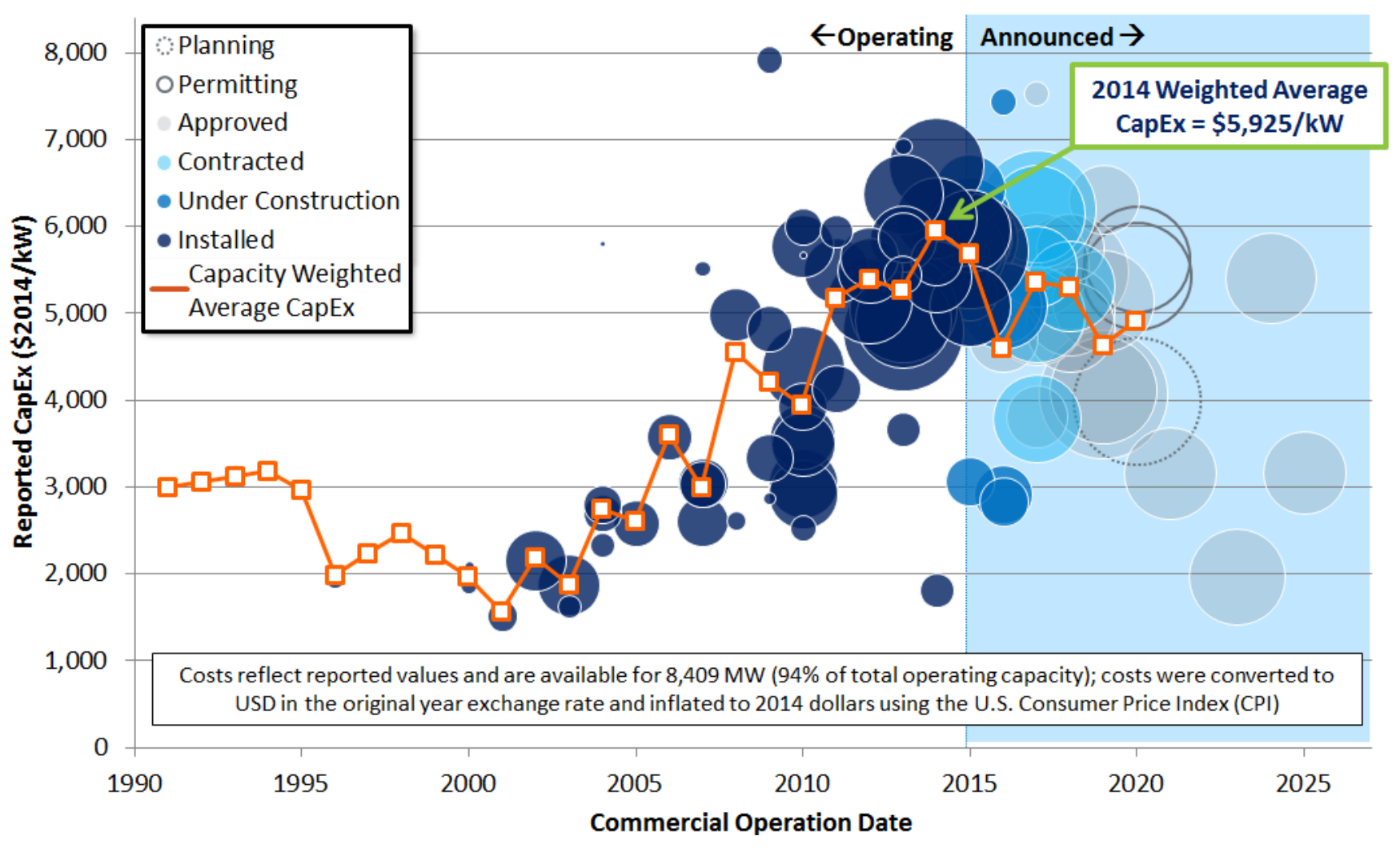

Figure 20. Global offshore wind projects weighted average capital expenditures by commercial operation date

Average CapEx has exhibited a strongly increasing trend over the past decade, roughly tripling in real terms from a low of approximately $\$ 2,000 /$ kilowatt $(\mathrm{kW})$ in the early 2000 s to a record high of $\$ 5,925 / \mathrm{kW}$ for the projects installed in 2014 . Changes in the cost structure during this period were driven by a number of factors, including: ${ }^{26}$

- Increasing technical difficulties of installing turbines in deeper water, farther from shore, and in more demanding metocean conditions (e.g., wind speeds, wave heights, and currents), which pose challenges for both technical design and construction

- Shortages in the supply chain (e.g., components, vessels, and skilled labor)

- Increasing prices for commodities and energy

- Macroeconomic trends including movements in exchange rates, commodity prices, and energy prices

- An improved appreciation of the costs and risks associated with offshore wind project implementation, leading to more conservative pricing strategies from equipment suppliers and installation contractors.

But 2014 may represent a peak in CapEx; data for the near-term pipeline suggests that the industry generally expects that average CapEx will decline and stabilize somewhere between

\footnotetext{
${ }^{26}$ For a full discussion, see UK Energy Research Centre (2010), Deloitte (2011), and Greenacre et al. (2010).
} 
$\$ 4,500 / \mathrm{kW}$ and $\$ 5,200 / \mathrm{kW}$ through 2020 . Yet, the trend beyond 2020 is quite unclear: the available data show considerable scatter and are limited to four projects that have only received regulatory approval but have yet to execute firm contracts for capital equipment.

Figure 21 shows CapEx data segmented by country and indicates that these expenditures are expected to trend downward in most markets from 2015 to 2020 (the data for Germany extend to 2025). The figure shows the third-order polynomials trend line for each country, which was found to provide the best fit, as well as the associated $\mathrm{R}^{2}$ value. ${ }^{27}$

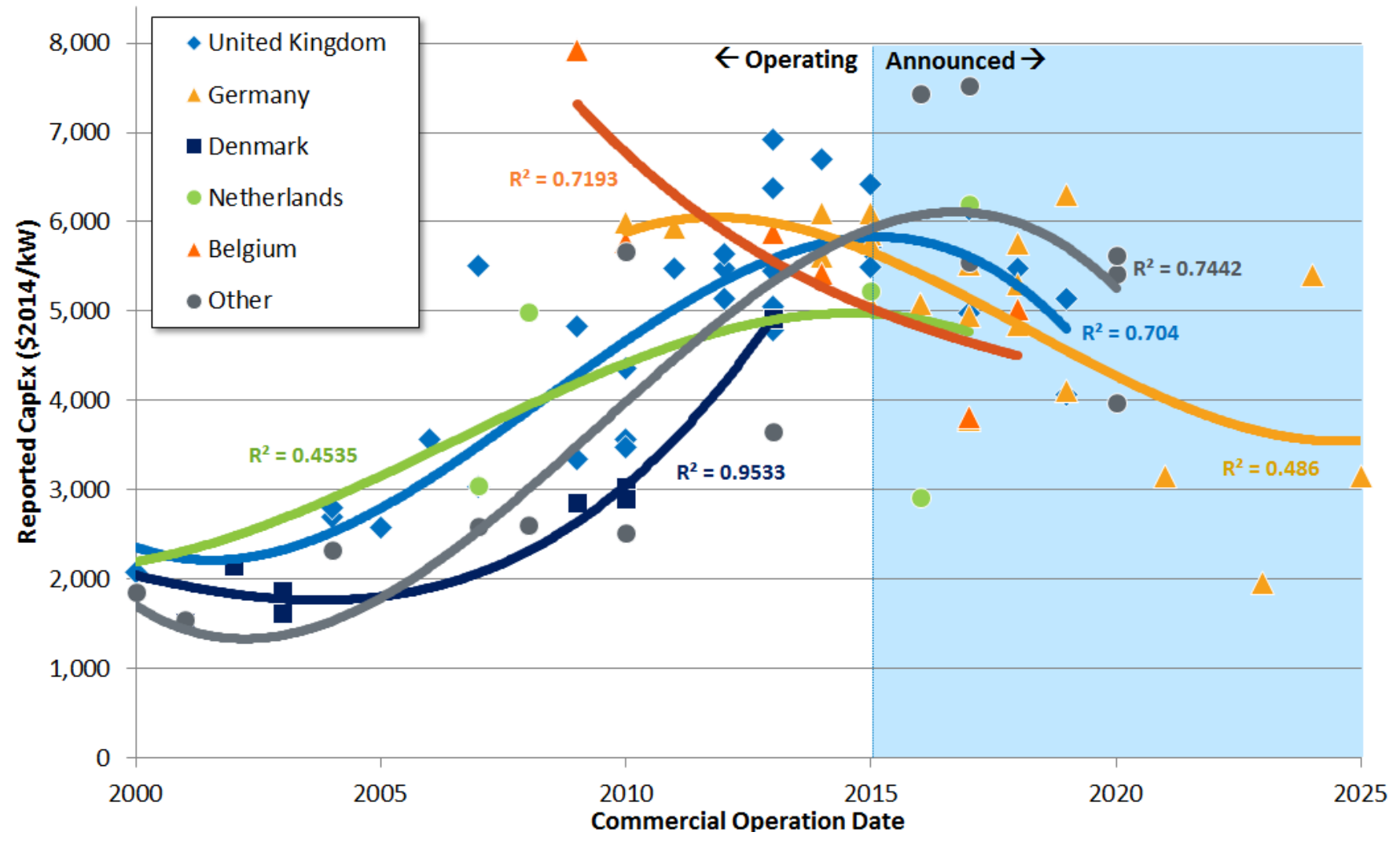

Figure 21. CapEx trends for offshore wind projects by country

Every market except Denmark shows an expected decline in CapEx in the near term. Denmark's lack of a marked decline is an anomaly, however, and could be misleading without additional context. No projects in Denmark have announced expected CapEx since the commissioning of the 400-MW Anholt projects in 2012. The next Danish project is expected to be Horns Rev III, which was just awarded a power feed-in tariff (FIT) that is $32 \%$ below the rate awarded to Anholt but is not shown on the chart because CapEx projections are not available. Although Vattenfall, the developer of Horns Rev III, has not yet published cost expectations, it is reasonable to suspect that the CapEx will be lower than Anholt, which should bring the Danish trend in line with the other countries.

\footnotetext{
${ }^{27} \mathrm{R}^{2}$ is a statistical measure that indicates how well a regression approximates the underlying data. An $\mathrm{R}^{2}$ of 1 would indicate that the regression provides a perfect fit, whereas an $\mathrm{R}^{2}$ of zero would indicate that there is no relationship between the regression and the underlying data.
} 


\subsubsection{Wind Turbine Capital Expenditures}

Offshore turbine costs are a significant fraction of the capital cost expenditures, with a percentage contribution estimated at between $30 \%$ and $45 \%$. For this report, turbine costs were compiled from publicly available data sources. Typically, turbine price data come from TSAs that are negotiated for each project, but because of their proprietary nature, these data are very limited. As a result, these limited data make statistical extrapolation of industry trends more difficult and raise some uncertainty in specific cost projections. Nevertheless, Table 5 provides a summary of the available turbine supply agreement cost data for $3,172 \mathrm{MW}$ of capacity $(\sim 20 \%$ of capacity) for projects with CODs between 2012 and 2017.

Table 5. Turbine Supply Agreement Costs

\begin{tabular}{|cccccccc|}
\hline Project Name & Country & $\begin{array}{c}\text { Order } \\
\text { Size } \\
\text { (MW) }\end{array}$ & OEM & $\begin{array}{c}\text { Turbine } \\
\text { Model }\end{array}$ & $\begin{array}{c}\text { Turbine Rating } \\
\text { (MW) }\end{array}$ & $\begin{array}{c}\text { Number of } \\
\text { Turbines }\end{array}$ & $\begin{array}{c}\text { Cost } \\
\text { (\$2014/kW) }\end{array}$ \\
\hline Dudgeon & $\begin{array}{c}\text { United } \\
\text { Kingdom }\end{array}$ & 402 & Siemens & SWT-6.0-154 & 6.0 & 67 & 2,112 \\
Witinger & Germany & 350 & Adwen & M5000-135 & 5.0 & 70 & 1,645 \\
Various & Germany & 1,494 & Senvion & 5M \& 6M & $5.0 \& 6.0$ & 250 & 2,053 \\
Gemini & Netherlands & 600 & Siemens & SWT-4.0-130 & 4.0 & 150 & 3,317 \\
Nordsee One & Germany & 332 & Senvion & 6 M & 6.15 & 54 & 1,998 \\
\hline
\end{tabular}

These publicly available TSA prices range from $\$ 1,645 / \mathrm{kW}$ to $\$ 2,112 / \mathrm{kW}$, with an average of $\$ 1,952 / \mathrm{kW}$, and typically include delivery to the staging port as well as a 5 -year warranty term. The turbine supply deal for Gemini is a clear outlier in this data set and excluded from the statistics mentioned above; the TSA price is $\$ 3,317 / \mathrm{kW}-57 \%$ higher than the next highest value. This difference is presumably because the contract includes turbine supply costs as well as a 15-year long-term service agreement that will see Siemens taking responsibility for the operation of the project (Radowitz 2014).

Variability in TSA prices is also likely introduced by differences in order size, commercial terms (e.g., warranty period and availability guarantees), and machine attributes (e.g., turbine rating and drivetrain topology). There is also evidence that turbine suppliers who are seeking to gain market share are willing to offer turbines at lower prices than OEMs that have existing market share and long-term operational experience. ${ }^{28}$

\subsection{Operational Expenditures}

OpEx covers all costs incurred after the COD—but before decommissioning - that are required to operate the project and maintain turbine availability to generate power. These expenditures are generally thought to contribute between $20 \%$ and $30 \%$ to life cycle costs for offshore wind projects, depending on site characteristics. The strongest drivers are distance from shore, accessibility limits related to local metocean conditions (e.g., wave height), and turbine rating (i.e., fewer, larger turbines suggest fewer transfers per megawatt). To optimize the balance between OpEx and availability, operators adopt different logistical strategies for individual projects depending on site conditions (DNV GL 2013).

\footnotetext{
${ }^{28}$ Insight based on NREL's involvement in the market and discussions with industry contacts.
} 
Operational expenditures for offshore wind projects are subject to considerable uncertainty because of a lack of empirical data. Although wind project owners almost always report CapEx, they rarely report OpEx. Uncertainty is further amplified because it is standard practice in the offshore wind industry for turbine OEMs to offer 5-year warranties, ${ }^{29}$ meaning that only projects installed before 2010, or just 3,400 MW of installed capacity, are subject to the full range of operating costs.

Industry and government stakeholders in the United Kingdom recognize that this lack of transparency could be a barrier to the industry in the future, obscuring potential cost reduction opportunities and failing to address investor risk perceptions. The ORE Catapult and The Crown Estate have partnered with U.K. wind plant owners to launch the System Performance, Availability and Reliability Trend Analysis, or SPARTA, in July 2015. The lead organizations announced that over half of operational capacity in the United Kingdom is now feeding data into the database and expects that data to enable cost reductions and performance improvements through enhanced operational best practices. The program aims to release aggregated data (e.g., fleet minimums, averages, and maximums) on performance metrics publicly, which should greatly improve the understating of operational costs and cost drivers (ORE Catapult and The Crown Estate 2014; The Crown Estate 2015).

\subsection{Performance}

Although a considerable amount of focus has been placed by industry and policymakers on the increases in project CapEx over the last decade, the increase in LCOE has been much smaller because plant performance has increased in parallel. Figure 22 shows the net capacity factor ${ }^{30}$ $\left(\mathrm{CF}_{\mathrm{NET}}\right)$ for offshore wind projects by $\mathrm{COD}$, segmented by country. These data cover $93 \%$ of operating projects $(8,290 \mathrm{MW}), 78 \%$ of projects under construction $(4,040 \mathrm{MW})$, and $71 \%$ of projects that have reached FID $(2,410 \mathrm{MW})$. The data come from a mix of sources including government-provided generation statistics and developer-reported values. Project performance in the near-term pipeline is based on expected generation rather than measured generation and should therefore be viewed with a degree of caution.

\footnotetext{
${ }^{29}$ Warranty costs are normally wrapped into TSA prices.

${ }^{30}$ Net capacity factor $\left(\mathrm{CF}_{\mathrm{NET}}\right)$ is a ratio of the actual energy delivered to the point of interconnection in a given period (typically a year) over the theoretical potential energy that could be delivered if the plant were to operate continuously at nameplate capacity over the same period of time. $\mathrm{CF}_{\mathrm{NET}}$ accounts for electrical losses, availability losses, and losses caused by environmental factors.
} 


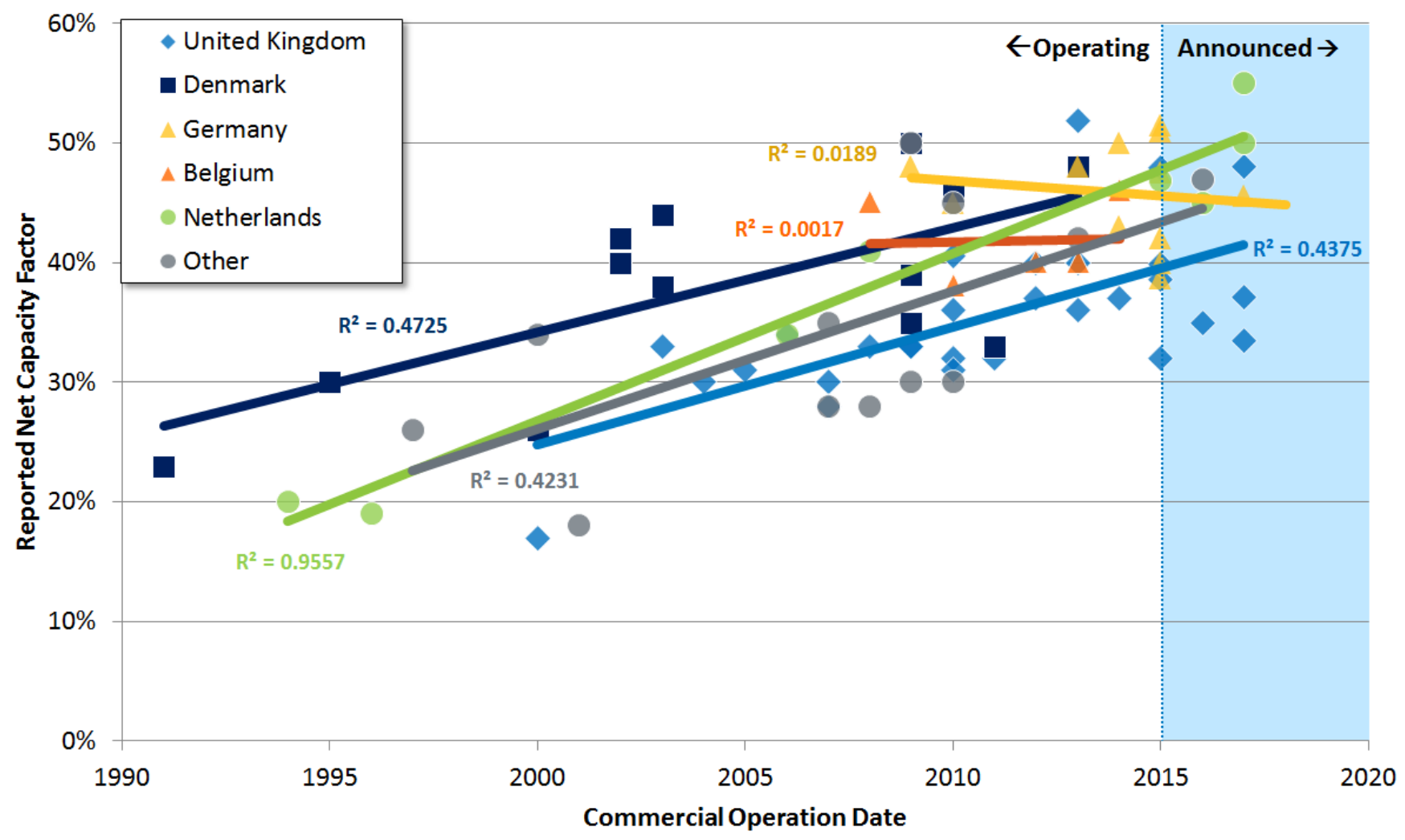

Figure 22. Net capacity factor for selected European offshore wind projects (by country)

The data in Figure 22 show that projects within all countries except for Belgium and Germany have experienced increasing net capacity factor with time. In general, capacity factors are improving for at least two reasons. First, siting decisions for initial projects emphasized locations that were close to shore and somewhat sheltered so that developers could gain experience before moving into open-ocean conditions. Offshore wind development zones are now increasingly located farther from shore to allow for larger projects and enable access to a more energetic and consistent wind resource. Second, offshore wind turbine technology has improved over the last decade (see Section 4.1); larger rotor-to-generator ratios increase the amount of energy that can be captured in a given wind resource and taller hub heights allow turbines to access higher wind speeds as a result of wind shear effects.

Belgium and Germany show flat and decreasing trends, respectively, and the poor fit for both of these trend lines suggests that there is no relationship between capacity factor and COD in these countries. Unlike offshore wind projects in other countries, the first projects in Belgium (the 30MW Thornton Bank I) and Germany (the 60-MW Alpha Ventus) were installed in unsheltered, open-ocean locations with high wind speeds, so their first deployments began with high capacity factors. The average capacity factors for Belgium (42\%) and Germany (47\%) are also higher than the global fleet-wide average of $37 \%$ for operating projects.

Capacity factors in the United States are expected to vary widely depending on the project location and turbine technology. The northeastern Atlantic has a very strong offshore wind resource, with average annual wind speeds between 9 and $10 \mathrm{~m} / \mathrm{s}$. Wind speeds gradually diminish from the north southward in the Atlantic and Gulf of Mexico, however, annual average 
wind speeds exceeding $8 \mathrm{~m} / \mathrm{s}$ can be found at locations that are far from shore, as well as areas towards the western edge of the Gulf of Mexico (Musial and Ram 2010). The 30-MW BIWF, for example, expects a net capacity factor of $47.5 \%$, which is comparable to net capacity factors at the best European project locations (AWS Truepower 2012).

\subsection{Financing Trends}

Offshore wind projects are capital-intensive, with utility-scale projects ( $>200 \mathrm{MW}$ ) generally requiring investments of more than $\$ 1$ billion. Because the majority of lifetime costs are incurred through the development and construction of the project, the LCOE is highly sensitive to the cost of financing. The effective cost of financing is typically expressed as the weighted average cost of capital (WACC), which averages the cost of all sources of capital based on the percentage contribution to the total capital structure. Holding all other assumptions constant, reducing the WACC by 100 basis points (a one-percentage-point reduction) will normally result in an LCOE savings of between $5 \%$ and $7 \%(\$ \sim 12 / \mathrm{MWh}$ to $\$ 15 / \mathrm{MWh})$. To take advantage of the monumental impact of WACC, offshore wind project owners are placing considerable effort on securing access to low-cost capital, which involves adopting project structures that minimize risk to investors as well as attracting new investor classes to the sector (PricewaterhouseCoopers 2012).

From the beginning of 2014 to the second quarter of 2015, the European offshore wind market saw significant financing activity. EWEA reports that 14 projects, totaling 4,146 MW, closed financing, with a total value of between $\$ 14.8$ and $\$ 16.9$ billion. About $43 \%$ of the total capacity that closed financing within the period was financed on a nonrecourse basis. EWEA estimates the total value of these nonrecourse debt transactions at approximately \$7 billion (EWEA 2015a; EWEA 2015b). The majority of investment activity was centered in Germany, the United Kingdom, and the Netherlands.

It is clear that a wide swath of investor classes, including commercial banks, institutional investors (e.g., pension funds, insurance funds, and infrastructure investors) and Japanese trading houses (e.g., Marubeni and Mitsubishi), are comfortable with the risks of offshore wind project investments. Freshfields (2014) reports that these investor classes are the most natural partners for utility developers; offshore wind projects offer stable cash flows over the project life and more attractive rates of return than many of the other investment opportunities in the current low-yield environment.

These partnerships are enabled by developers, such as DONG Energy, that minimize the exposure of these investors to construction risk by accepting responsibility for cost overruns and schedule delays. Construction risk can also be minimized through contracting structure. By dividing construction and procurement work packages into a small number of fixed-price contracts with well-defined interfaces, the developer can limit the exposure of investors to construction risk (Freshfields 2014). Multilateral institutions, such as export credit agencies and public financial institutions, have played key roles in attracting debt investors to the market by providing debt and repayment guarantees.

Even though transferring construction risk to contractors can be expensive from a CapEx perspective, these additional costs can be offset by the benefits of attracting low-cost investors into the financing package, thereby reducing WACC. The emphasis on securing low-cost sources of capital to minimize LCOE, as well as the large capital requirements associated with offshore 
wind projects, are expected to accelerate the trend towards financing structures that incorporate nonrecourse debt. ${ }^{31}$ In 2015, RWE closed on the 332-MW Nordsee One project, becoming the first major utility to adopt a nonrecourse financial structure for an offshore wind project (Freshfields 2014).

Currently, more than 20 banks are active in nonrecourse debt transactions for offshore wind projects, investing as a club and syndicating further to smaller banks entering the arena. In addition, banks have increased the maximum amount that they are willing to underwrite on a given deal from \$40-\$65 million in 2012 to \$130-\$200 million in 2013/2014 (Guillet 2015). Liquidity available to the sector has grown and some commentators expect that it will expand further with the arrival of major Asian banks such as the Bank of Tokyo, which had committed to underwrite the debt package for the 468-MW Cape Wind project in the United States before the status of the PPA came into question. As evidence of this liquidity, the recently financed Nordsee One project was fully funded within 6 months, with the debt offering oversubscribed and without participation from any multilateral institutions. Also, the 600-MW Gemini project closed, with approximately $\$ 2.9$ billion in debt, making it the largest single offshore wind transaction to date and proving that project size is no longer a barrier to attracting debt investors.

Despite the fact that there is limited data about rates of return, debt for European offshore wind projects is estimated to be priced at 250 and 350 basis points (bps) above the London Interbank Offer Rate, representing a $20-50$ bps premium above prices for land-based wind projects. ${ }^{32}$ This pricing suggests that the all-in cost of debt, after accounting for the cost of interest rate hedges over the full loan amortization period, ranges between 4.5\% and 5.5\% (Freshfields 2014).

Debt terms are generally characterized by the following elements:

- Debt-to-equity ratios between 50:50 and 80:20

- Debt service coverage ratios between 1.25 and 1.4

- Tenors varying between 10 and 15 years, depending on the market; the tenor is limited by the term of the subsidy available to the project to include a 2-5 year buffer between the loan repayment date and end of the power offtake agreement

- A debt service reserve account and a maintenance service reserve account that contain enough liquidity to cover 3-6 months of debt obligations and maintenance expenditures, respectively.

In 2015, the 30-MW BIWF became the first U.S. offshore wind project to close financing, with a package valued at $\$ 290$ million and proving that financiers are willing to invest in projects in the U.S. market. The nonrecourse debt package was provided by Societe Generale and Keybank, and

\footnotetext{
${ }^{31}$ Nonrecourse debt is an investment in which the providers (typically commercial banks) supply capital that only has claims on the future cashflows of the project and does not include claims on equity investor assets beyond the boundary of the project. As such, these investors are conservative and conduct considerable due diligence to ensure that their downside risk exposure (in which returns are lower than expected) is limited.

${ }^{32}$ Freshfields (2014) reports that some interviewees are uncomfortable with these low rates of return, quoting Federico Florian of KfW IPEX-Bank, "Margins are dangerously low, in my view, if you compare the risks of offshore wind lending versus onshore and the pricing differential does not reflect this. There is only a $20 \mathrm{bps}$ difference in pricing on average."
} 
is matched by $\$ 70$ million in equity provided by a division of the D.E. Shaw Group, the principal owner, and Sun Edison (Deepwater Wind 2015). The \$360-million capital structure will cover the $\$ 225$ million required to construct the project, as well as transaction fees, insurance, and the initial costs of operation. The deal does not cover the $\$ 107$ million cost of the subsea cable that will connect Block Island to the electric grid on the mainland; National Grid is responsible for that portion of the project (Kuffner 2015b).

This financial structure implies a debt-to-equity ratio of 80:20, which is more aggressively leveraged than most of the nonrecourse debt deals closed in Europe to date. Although few details about the deal have been made public, industry sources have suggested that the debt was priced at levels that are comparable to those observed in Europe.

\subsection{Evidence of Levelized Cost of Energy Reduction}

Government agencies and public-private partnerships have sponsored several studies to gain insight into the cost reduction potential that can be achieved through technology innovation, industrialization of the supply chain, policy design, and financing improvements. ${ }^{33}$ Each of these studies found significant potential to reduce the cost of energy from base year values through the early 2020s, and provided information about the conditions that governments can create to enable lower costs. Stakeholders and policymakers have used findings from these reports to set LCOE goals: $£ 100 / \mathrm{MWh}(\$ 164 / \mathrm{MWh})$ in the United Kingdom, where the developer is responsible for offshore transmission charges, and $€ 100 / \mathrm{MWh}(\sim \$ 130 / \mathrm{MWh})$ in the European Union, where transmission charges are generally the responsibility of the TSO. Policymakers have also used insights from the reports to define schemes that support deployment at current cost levels but gradually ratchet down future-year incentives to match the anticipated cost trajectory.

The emphasis on cost reduction and corresponding reduction in subsidy levels available to projects in future years is driving innovations across offshore wind plant systems, which are being quickly adopted by developers. Section 4 describes the rapid adoption of larger, advanced turbine technologies, as well as innovations in foundation design, installation techniques, and electrical infrastructure. These innovations are expected to reduce CapEx and OpEx and improve performance.

Further cost reduction is driven by the increasing maturity of the supply chain, enabled by increasing annual deployment numbers in Europe, where governments have provided visibility about the market size through 2020. This visibility attracts additional participants into the supply chain, increasing competition, and allows them to invest in purpose-built manufacturing facilities, infrastructure, and vessels. Some developers, such as DONG Energy, have entered framework agreements for the supply of standard components that can be used across multiple projects. Such agreements for components like substations, which have been historically fabricated for individual offshore projects with custom, project-specific designs, can enable suppliers to take a production-line approach to fabrication, thereby reducing costs (Juul 2014). Willow and Valpy (2015) report that the U.K. government could likely reduce cost of energy by

\footnotetext{
${ }^{33}$ See The Crown Estate (2012), Hobohm et al. (2013), TKI Wind Op Zee (2013), Valpy et al. (2014), and McClellan et al. (2015).
} 
$24 \%$ through 2030 by providing the supply chain with visibility and confidence that market size would be sustained at around 1,500 MW per year.

The push for cost reduction is being assisted by European Union policymakers, who are adopting programs designed to lower costs, reduce risk to developers, and minimize the prices required to make projects financially viable. Examples of some of these efforts are described as follows.

Governments in Denmark, the Netherlands, and Belgium are sponsoring site characterization activities (e.g., geotechnical surveys, wind resource studies, and environmental studies) and partially permitting zones prior to holding auctions for development rights and power offtake agreements. Increasing the amount of data that developers have access to before an auction for subsidies or development rights can reduce uncertainty and provide developers with the ability to predict costs and performance with improved certainty. Less risk generally means that developers can reduce contingencies and offer lower power prices.

Policymakers in Europe are moving away from setting fixed offtake prices at a national level and are now implementing auctions to encourage competition between developers. When properly designed, these auctions help policymakers discover the minimum price support required for individual projects and ensure that ratepayers get the best deal possible. Denmark conducts competitive auctions for prepermitted lease zones using power price as the main criteria; the winner of the lease auction is also awarded a FIT contract that provides a subsidy for the first 50,000 full load hours of operation (ENS 2014). The Netherlands, Belgium, and Germany are all taking steps towards implementing this type of system. The United Kingdom, which has already awarded lease rights to developers, has now implemented a system that requires developers to compete for a limited pot of funding by submitting power offtake price bids. The lowest cost bids receive a 15 -year contract for difference (CFD), which provides a fixed price per megawatthour to the project irrespective of movements in wholesale power prices.

Denmark has eliminated requirements for developers to include local content in the supply chain as a condition for receiving a FIT contract. This elimination allows developers to make procurement discussions purely based on economic factors, which should allow them to deliver the project at the lowest possible price.

Recent empirical data suggest that costs have stabilized, and many industry experts expect decreases through 2020. The U.K. government, through ORE Catapult, has set up the offshore CRMF to track the progress of the industry in meeting the cost target of $£ 100 / \mathrm{MWh}$ ( \$164/MWh) for projects that reach FID in 2020 (COD nominally 2022). The CRMF collected LCOE data by surveying the developers of 10 projects $(3,078 \mathrm{MW})$ that reached COD between 2010 and 2014, and six projects (1,793 MW) that had reached FID within the same time period. The CRMF report, released in 2015, concludes that average LCOE has declined from $£ 136 / \mathrm{MWh}$ (\$235/MWh) for projects built in 2010/2011 to £121/MWh (\$209/MWh) for projects reaching FID between 2012 and 2014, an 11\% reduction (ORE Catapult 2015).

In 2015, Denmark and the United Kingdom held competitive auctions for price support, which resulted in the lowest power prices for offshore wind in recent history. Vattenfall won the competitive tender for the 400-MW Horns Rev III project in Denmark and will receive a subsidy of $770 \mathrm{DKK} / \mathrm{MWh}(\$ 134 / \mathrm{MWh})$ for the first 50,000 MWh of operation (Lee 2015b). In the United Kingdom, CFDs were awarded to Mainstream Renewable Power for the 448-MW Neart 
Na Gaoithe project and to Iberdrola for the 714-MW East Anglia ONE project. ${ }^{34}$ The winning bids for these projects were $£ 114.4 / \mathrm{MWh}(\$ 184.5 / \mathrm{MWh})$ and $£ 119.9 / \mathrm{MWh}(\$ 193.3 / \mathrm{MWh})$, respectively (Lee 2015c). ${ }^{35}$

There are significant uncertainties associated with comparing power take-off prices because of differences in project scope (e.g., in the United Kingdom, developers are responsible for grid connection, whereas in Denmark that responsibility lies with the TSO), market structure (e.g., tax rate and depreciation structure), site characteristics (e.g., wind speed, water depth, and distance from shore), and contractual terms and conditions (e.g., contract length and treatment of inflation).

Real LCOE offers a better metric for comparison and can be approximated by averaging the total revenue stream that the project would anticipate over its lifetime and accounting for the effects of inflation. ${ }^{36}$ Table 6 summarizes the revenue sources for each of these three projects, including the first-year value of the main subsidy (CFD or FIT), the term of the subsidy, the value of other subsidies that may be available to the project, the treatment of inflation, and the average wholesale power price available to the project after the subsidy expires. ${ }^{37}$

Table 6. Summary of Lifetime Revenue for Horns Rev III, Neart Na Gaoithe, and East Anglia ONE

\begin{tabular}{|c|c|c|c|c|c|c|}
\hline Project & $\begin{array}{c}\text { Target } \\
\text { COD }\end{array}$ & $\begin{array}{c}\text { First Year } \\
\text { CFD/FIT } \\
\text { (\$2014/MWh) }\end{array}$ & $\begin{array}{l}\text { Subsidy } \\
\text { Term } \\
\text { (years) }\end{array}$ & $\begin{array}{l}\text { Other Subsidies } \\
\text { (\$2014/MWh) }\end{array}$ & $\begin{array}{c}\text { Inflation } \\
\text { Adjusted } \\
(\mathrm{Y} / \mathrm{N})\end{array}$ & $\begin{array}{c}\text { Average Power } \\
\text { Price } \\
\text { (\$2014/MWh) }\end{array}$ \\
\hline Horns Rev III & 2020 & $\$ 134$ & $12^{\mathrm{a}}$ & NA & $\mathrm{N}$ & $\$ 63^{b}$ \\
\hline Neart Na Gaoithe & 2019 & $\$ 184$ & 15 & $N A^{c}$ & $Y$ & $\$ 94^{d}$ \\
\hline East Anglia ONE & 2020 & $\$ 193$ & 15 & $N A^{c}$ & $Y$ & $\$ 94^{d}$ \\
\hline
\end{tabular}

${ }^{a}$ Subsidy term based on 50,000 full load hours, which suggests a term of 12 years (Lee 2015b)

${ }^{\mathrm{b}}$ Danish wholesale market price estimated from Energinet.dk (2013) using the average from 2020 to 2035

${ }^{c}$ The U.K. levy exemption credit (tax credit valued at \$8.7/MWh) was discontinued in July 2015 (Lee 2015d)

${ }^{\mathrm{d}}$ U.K. market price estimated from National Grid (2014) by averaging the base case scenario from 2010 to 2035.

\footnotetext{
${ }^{34}$ The project was originally being developed by a consortium involving Vattenfall and ScottishPower Renewables (an Iberdrola subsidiary); however, the developers agreed that Iberdrola would lead development (Hopson 2015).

${ }^{35}$ All values were converted using 2014 average exchange rates and reflect 2014 cost levels for consistency with the methodology in the rest of this report. If converted at 2015 exchange rates, in which the dollar has appreciated against both the euro and the pound, the subsidy values would be \$111/MWh for Horns Rev III, \$169/MWh for Neart Na Goithe, and \$177/MWh for East Anglia ONE.

${ }^{36}$ Note that this method is not perfect. A better method of approximating LCOE would be to use a discounted cash flow model with project-specific assumptions about CapEx, OpEx, energy production, and financial structure. Unfortunately, however, these values are unknown for the projects in question, which introduces some uncertainty into the analysis.

${ }^{37}$ Note that future wholesale power prices are highly uncertain and depend on a number of factors that are complicated to project. For example, Vitina et al. (2015) found that different projections of Danish wholesale power prices in 2035 ranged from $€ 30 / \mathrm{MWh}$ to $€ 80 / \mathrm{MWh}(\$ 40 / \mathrm{MWh}$ to $\$ 104 / \mathrm{MWh})$. Further, the price that wind producers receive can vary relative to the average price in markets that use time-of-day pricing, depending on the site-specific diurnal production profile (Vitina et al. 2015).
} 
The values in Table 6 are used to approximate the nominal revenue ( $\$ \mathrm{MWh})$ that each project could expect to earn in each year over a 20 -year operating life. Real LCOE is then estimated by discounting annual revenue ( $\$ \mathrm{MWh})$, applying an assumed inflation rate of $2 \%$ and then averaging the total revenue stream across the operating life (see Appendix F for details). This methodology yields LCOE estimates of \$95/MWh for Horns Rev III, \$160/MWh for Neart Na Gaoithe, and \$167/MWh for East Anglia ONE. ${ }^{38}$ Note that the estimate for Horns Rev III does not include transmission charges (estimated at $20 \%-30 \%$ of life cycle cost), whereas the projects in the United Kingdom include these charges. To normalize the comparison to the same project scope, NREL applied a 25\% adder to the Horns Rev III LCOE to approximate the cost of transmission charges, which results in an LCOE of \$120/MWh.

Even after making this adjustment, the differences between projects are still on the order of $\$ 40 / \mathrm{MWh}$ to $\$ 45 / \mathrm{MWh}$. These differences can largely be attributed to: ${ }^{39}$

- Site characteristics. Horns Rev III is located in shallow water $(15 \mathrm{~m})$, is relatively close to shore $(30 \mathrm{~km})$, and has a very energetic wind resource $(9.8 \mathrm{~m} / \mathrm{s}$ at $100 \mathrm{~m}$ above mean sea level). By contrast, East Anglia ONE is in deeper water (37 m), is farther from shore (45 $\mathrm{km})$, and has a less energetic wind resource $(9.5 \mathrm{~m} / \mathrm{s}$ above mean sea level).

- Policy conditions. The Danish government takes responsibility for some of the development costs and waives seabed lease costs, which reduces the costs and risks associated with construction and operations. Further, the final subsidy tariff is negotiated between the developer and the government, which may reduce the final price relative to the original price that won the competitive bid.

- Market structure. Although tax codes, including tax rates and depreciation schedules, were not examined in this analysis, these structural differences can have sizable effects on LCOE.

- Technology. Horns Rev III will use Vestas V164 8-MW turbines, whereas both Neart Na Gaoithe and East Anglia ONE will use Siemens SWT-7.0-154 turbines.

- Financial structure. Even though no details have emerged about the financial structures for any of these projects, differences in financing rates can have a large impact on LCOE.

Figure 23 compares the U.K. cost reduction goals to the previously mentioned empirical evidence, including the U.K. CRMF study results and LCOE estimates for Horns Rev III, Neart $\mathrm{Na}$ Gaoithe, and East Anglia ONE. To normalize the comparison to the same project scope, NREL increased the LCOE of the Horns Rev III project by $25 \%$ to approximate the cost of transmission charges, which are not within the project's scope.

\footnotetext{
${ }^{38}$ The LCOE estimates are naturally lower than the CFDs/FITs for the following reasons: 1) LCOE is calculated over a longer term than CFD/FIT contracts, so these contracts need to have higher prices to allow the developer to recover a suitable return, 2) LCOE does not take into account the cost associated with selling electricity on the wholesale market, 3 ) there are timing delays between generating electricity and receiving revenue (ORE Catapult 2015).

${ }^{39}$ See Prinsen 2015 and Stridbaek 2015.
} 


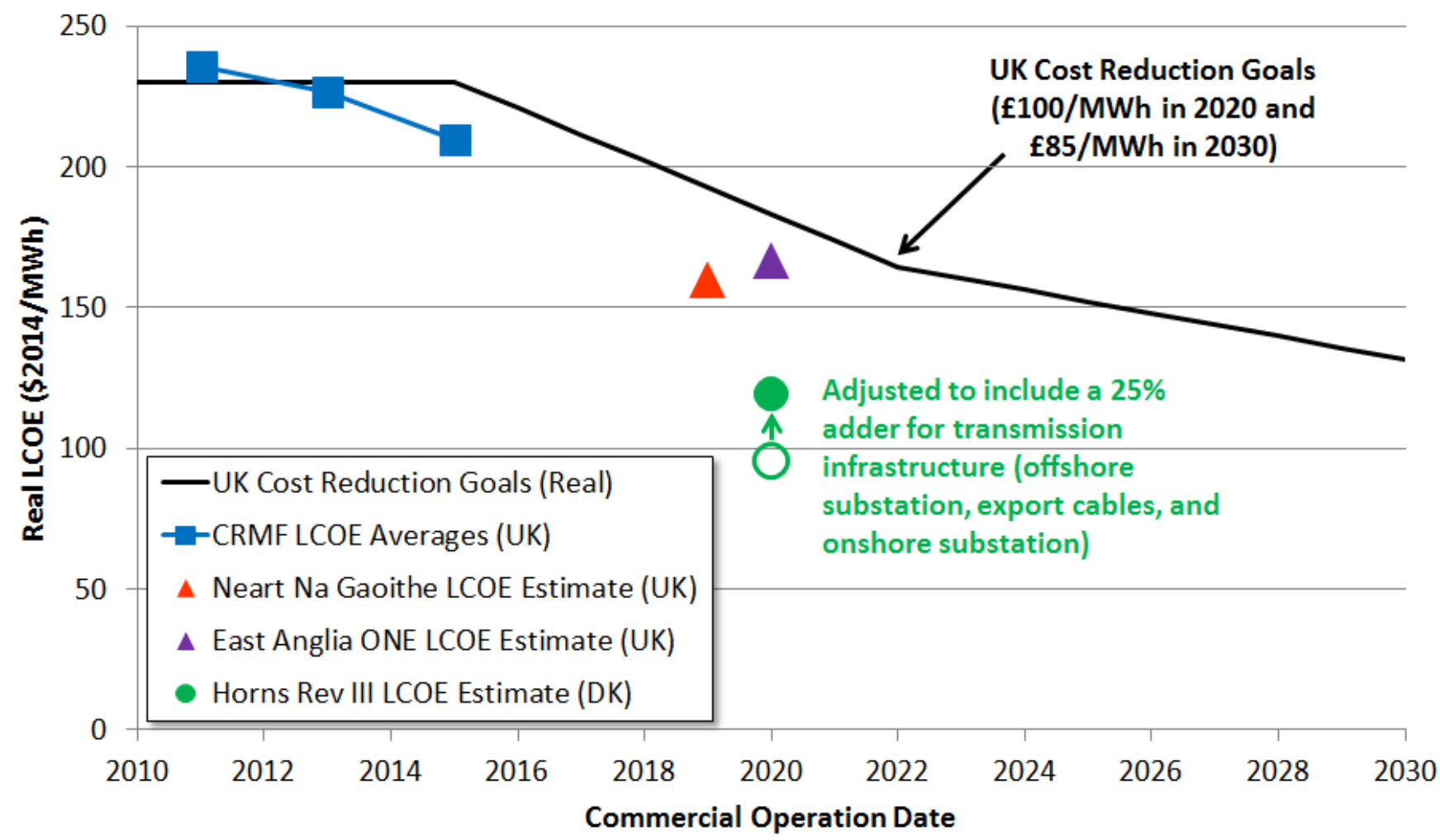

Figure 23. European LCOE estimated from empirical surveys and subsidy auction results

Note: Real LCOE is approximated by averaging the total revenue stream (subsidy tariff and market price) over the project lifetime. Converted to U.S. dollars assuming 2014 exchange rates and normalized to \$2014 using inflators from the U.S. Bureau of Labor Statistics.

The results, which incorporate the best available information about the costs of current and future offshore wind projects, show that the industry is well in advance of the trajectory required to reach its goals for projects where recent LCOE and/or pricing data were available. The key driver, according to the CRMF, is the commercialization and rapid adoption of turbines with larger nameplate ratings (6-8 MW) and increased power conversion efficiency. These larger machines reduce CapEx and OpEx by minimizing the number of units that must be installed and maintained while increasing performance. Other innovations in vessel technology and balance of systems are also contributing to the lower cost levels (ORE Catupult 2015). NREL analysis suggests that favorable macroeconomic factors also play a role, such as stable commodity prices, low activity in the offshore oil and gas sector, and international exchange rates.

The CRMF cautions that, despite making faster-than-expected progress towards targets, the industry needs certainty on future deployment volumes. Supply chain participants need to be reasonably confident that the technology and infrastructure investments necessary to further reduce costs will be utilized (ORE Catupult 2015). 


\section{Conclusion}

This report provides data and analysis to assess the status of the U.S. offshore wind industry through June 30, 2015. It builds on the foundation laid by the Navigant Consortium, which produced three market reports between 2012 and 2014. The report focuses on the aspects of the offshore wind industry that change annually and provides an objective summary of domestic and global market developments, technology trends, and economic progress to help stakeholders identify barriers and opportunities. The report introduces a new methodology to assess project status, which adds more resolution to the classification of projects in the U.S. pipeline by using discrete categories with clearly defined beginning and endpoints that are relevant to U.S. and international regulatory processes. The new system allows improved tracking of project progress through the development and operational life cycle.

There are 21 U.S. offshore wind projects in the development pipeline, representing 15,650 MW of offshore wind as of June 30, 2015. Out of the 21 projects in the development pipeline, 13 projects, representing 5,939 MW, have achieved site control or a more advanced phase of development. These 13 projects are highlighted in this report, with particular focus on the 30MW BIWF, the first U.S. project to have "steel in the water" with commercial operations expected to begin in the fall of 2016. Approximately 3,024 MW of U.S. projects have announced a COD before 2020, which is consistent with the timing of the deployment scenario laid out in DOE's Wind Vision. Beyond 2020, the Wind Vision calls for the deployment of 22,000 MW by 2030 and $86,000 \mathrm{MW}$ by 2050 ; with deployment in all major regions as the industry grows.

This report summarizes the progress of the global offshore wind industry, which had installed 8,890 MW by June 30, 2015, and is poised to set a record for annual installations with 3,990 MW of new capacity expected to begin operations in 2015. Although the majority of this capacity is being built in Europe, the industry is becoming more geographically dispersed with projects now underway in the Asian and U.S. markets. Recent evidence from industry surveys and competitive subsidy auctions in Europe suggests that the LCOE is declining from a peak in 2014. Data from recently awarded projects suggests that the industry is on track to meet cost reduction targets.

This report presents analysis of technology trends that illustrate how projects are increasingly being sited in greater water depths and farther from shore. These characteristics impose new technical requirements for offshore wind projects and have contributed to the increase in CapEx observed from 2005 to 2014 . Future cost projections, however, suggest that technology innovation and industry scale could drive a decline in LCOE through 2020. Some policymakers in the European Union are amplifying the impacts of technology innovation by designing policies that reduce risk for developers, lower the prices required to make projects financially viable, and minimize costs to ratepayers.

The progress towards cost reduction in the European offshore wind energy industry should translate to U.S. projects and allow developers to offer offshore wind power at increasingly competitive prices relative to other low-carbon sources of generation. The BIWF and ATD program are expected to enable the U.S. industry to gain valuable experience by using the bestavailable European technology, as well as other project-specific innovations, to adapt the technology to U.S. siting challenges. These projects are expected to help streamline and de-risk 
offshore wind investment in the United States by exercising the permitting process, generating important information about U.S. operating conditions, and showcasing the capabilities of the U.S. supply chain. The experience gained should illuminate opportunities as well as barriers to offshore wind development in the United States. This knowledge can be used by stakeholders to improve processes and guide the investment in equipment and infrastructure that could shorten deployment timelines and reduce LCOE for the next generation of commercial projects. 


\section{References}

4C Offshore. 2015. European Offshore Wind Overview. http://www.4coffshore.com/windfarms/reports/europeOverviewReport.aspx.

Abel, David. "Cape Wind's future called into question." January 8, 2015. The Boston Globe. Accessed August 2015. https://www.bostonglobe.com/metro/2015/01/08/legal-wranglinghorizon-for-cape-wind-after-major-utilities-pull-out/kIEXaT5x4lkfUplijpdtsL/story.html.

AREVA. "Gamesa and AREVA Create the Joint-Venture Adwen." March 9, 2015. Accessed August 2015. http://www.areva.com/EN/news-10478/gamesa-and-areva-create-the-jointventureadwen.html.

AWS Truepower. 2012. Block Island Wind Farm Energy Production Estimate. Prepared for Deepwater Wind. http://dwwind.com/wp-content/uploads/2014/08/BIWF-EnergyProduction.pdf.

BOEM. "BOEM issues first wind energy research lease in Federal offshore waters." March 24, 2015. U.S. Department of the Interior Bureau of Ocean Energy Management. Accessed August 2014. http://www.boem.gov/press03242015a/.

Broehl, J.; Labastida, R. R.; Hamilton, B. 2015. World Wind Energy Market Update 2015. International Wind Energy Development: 2015-2019. BTM Consult. https://www.navigantresearch.com/research/world-wind-energy-market-update-2015.

Brown, E. (2015). "Governor Brown Establishes Most Ambitious Greenhouse Gas Reduction Target in North America." California Office of the Governor. Accessed August 2015. http://gov.ca.gov/news.php?id=18938

Buchanan, Susan. "Offshore O\&G: Weathering the Storm.” May 28, 2015. Marine News. Accessed August 2015. http://www.marinelink.com/news/weathering-offshorestorm392017.aspx.

BLS. 2015. CPI Detailed Report (complete text and tables, including second half 2014 semiannual averages and 2014 annual averages). U.S. Bureau of Labor Statistics. Accessed August 2015. http://www.bls.gov/cpi/cpid1501.pdf.

BVG Associates. 2012. Offshore wind cost reduction pathways technology work stream. The Crown Estate. London. http://www.thecrownestate.co.uk/media/5643/ei-bvg-owcrp-technologyworkstream.pdf.

Campbell, Shaun. "Europe's offshore leader faces slower year." February 27, 2015. Windpower Offshore. Accessed August 2015. http://www.windpoweroffshore.com/article/1335234/europesoffshore-leader-faces-slower-year.

Campbell, Shaun. (2015). Europe's offshore leader faces slower year .Windpower Offshore. Accessed August 2015. http://www.windpoweroffshore.com/article/1335234/europes-offshoreleader-faces-slower-year. 
Carbon Trust. "Carbon Trust awards funding to cut offshore wind costs by up to $£ 100 \mathrm{~m}$ per year." July 15, 2014. Accessed August 2015. http://www.carbontrust.com/aboutus/press/2014/07/carbon-trust-awards-funding-to-cut-offshore-wind-costs-by-up-to-100m-peryear.

Carbon Trust. 2015a. Floating Offshore Wind: Market and Technology Review. Prepared for the Scottish government. http://www.carbontrust.com/media/670664/floating-offshore-wind-markettechnology-review.pdf.

Carbon Trust. 2015b. "Charting the course for offshore access systems.” April 30, 2015. Accessed August 2015. http://www.carbontrust.com/news/2015/05/charting-the-course-foroffshore-access-systems/.

Daniel, John, Liu, Shu, Ibanez, Eduardo, Pennock, Ken, Reed, Gregory, Hanes, Spencer. 2014. National Offshore Wind Energy Grid Interconnection Study Final Technical Report. DOE Award No. EE-0005365. http://energy.gov/sites/prod/files/2014/08/f18/NOWEGIS\%20Full\%20Report.pdf.

de Blasio, Bill. "De Blasio Administration Moves to Power 100 Percent of City Government From Renewable Sources of Energy. July 10, 2015. City of New York. Accessed August 2015. http://www1.nyc.gov/office-of-the-mayor/news/478-15/de-blasio-administration-moves-power100 -percent-city-government-renewable-sources-of.

De Clercq, Geert. "French offshore wind industry hopes to catch up with Germany." December 1, 2014. Reuters. Accessed August 2015. http://www.reuters.com/article/2014/12/01/francewind-offshore-idUSL6N0TL3RW20141201.

De Clercq, G. "France launches tender for floating offshore wind projects." August 5, 2015. Reuters. Paris. Accessed August 2015. http://www.reuters.com/article/2015/08/05/us-francewindpower-floating-idUSKCN0QA26E20150805.

De León and Leno. SB-350 Clean Energy and Pollution Reduction Act of 2015. February 24, 2015. California Legislature. Accessed September 2015. http://leginfo.legislature.ca.gov/faces/billNavClient.xhtml?bill_id=201520160SB350

Deepwater Wind. "Deepwater Wind Wins Auction to Develop Offshore Wind Energy Sites in Federal Waters." (2013). Accessed August 2015. http://dwwind.com/press/deepwater-windwins-auction-develop-offshore-wind-energy-sites-federal-waters/.

Deepwater Wind. "Block Island Wind Farm Now Fully Financed.” (2015). Accessed August 2015. http://dwwind.com/press/block-island-wind-farm-now-fully-financed/.

Del Franco, Mark. 2015a. "How Offshore Wind Can Power a State's Economic Revival." North American Windpower. Accessed August 2015. http://www.nawindpower.com/issues/NAW1508/FEAT 01 How-Offshore-Wind-Can-Power-AState-s-Economic-Revival.html. 
Del Franco, Mark. 2015b. "Dominion Virginia Power Puts The Breaks On Offshore Wind Pilot Project." North American Windpower. Accessed August 2015.

http://www.nawindpower.com/e107 plugins/content/content.php?content.14157.

Deloitte. 2011. Analysis on the Furthering of Competition in Relation to the Establishment of Large Offshore Wind Farms in Denmark. The Ministry of Climate and Energy (ENS). https://stateofgreen.com/files/download/382.

DNV GL. 2013. A Guide to UK Offshore Wind Operations and Maintenance. Scottish Enterprise and The Crown Estate. http://www.scottish-enterprise.com/knowledgehub/articles/guide/offshore-wind-operations-and-maintenance-opportunities.

DNV GL. 2015. Cost Reduction Monitoring Framework: Qualitative Summary Report. ORE Catapult and The Crown Estate. https://ore.catapult.org.uk/documents/10619/110659/CRMF+Qualitative+Summary+report/dc37f b9c-e41e-429c-862e-747f8db091c0.

DOE. 2015. WindVision: A New Era for Wind Power in the United States. U.S. Department of Energy Office of Energy Efficiency \&Renewable Energy. DOE/GO-102015-4557. http://www.energy.gov/sites/prod/files/WindVision_Report_final.pdf.

Dominion. (2015). "Virginia Commercial Offshore Leased WEA." Accessed August 2015. https://www.dom.com/corporate/what-we-do/electricity/generation/wind/virginia-commercialoffshore-leased-wea.

DOI. (2015a). Interior Department Leases Area Offshore Massachusetts for Wind Energy Development. Department of the Interior Office of the Secretary. Accessed August 2015. https://www.doi.gov/news/pressreleases/interior-department-leases-area-offshoremassachusetts-for-wind-energy-development.

DOI. (2015b). Secretary Jewell, Director Hopper Laud Construction of Nation's First Offshore Wind Farm. Department of the Interior Office of the Secretary. Accessed August 2015. https://www.doi.gov/pressreleases/secretary-jewell-director-hopper-laud-construction-nation \%E2\%80\%99s-first-offshore-wind-farm.

DONG Energy. "Innovative suction bucket jacket foundation hits ground bed." (2014). Accessed August 2015. http://www.dongenergy.com/en/media/newsroom/news/articles/innovativesuction-bucket-jacket-foundation-hits-ground-bed.

DONG Energy. "DONG Energy takes over US offshore wind development project." (2015). Accessed August 2015. http://www.dongenergy.com/en/investors/companyannouncements/company-announcement-detail?omxid=812698.

Douglas Westwood. 2014. Assessment of Vessel Requirements for the U.S. Offshore Wind Sector. U.S. Department of Energy Office of Energy Efficiency and Renewable Energy. http://wind.energy.gov/pdfs/assessment vessel requirements US offshore wind report.pdf. 
EC Harris. 2012. Offshore Wind Cost Reduction Pathways-Supply Chain Work Stream. The Crown Estate. http://www.thecrownestate.co.uk/media/5614/ei-echarris-owcrp-supply-chainworkstream.pdf.

Elkington, Chris, Blatiak, A., Ameen, H. 2013. Assessments of Ports for Offshore Wind Development in the United States. GL Garrad Hassan. Accessed August 2015. http://energy.gov/sites/prod/files/2014/03/f14/Assessment $\% 20$ of $\% 20$ Ports $\% 20$ for $\% 20$ Offshore $\%$ 20Wind $\% 20$ Development $\% 20 \mathrm{in} \% 20$ the $\% 20$ United $\% 20$ States_1.pdf.

Energinet.dk. 2013. Energinet.dk's analysis assumptions 2012-2035. Doc. 78842/13, Case $12 / 427$.

http://energinet.dk/SiteCollectionDocuments/Engelske\%20dokumenter/El/Energinet.dk\%20Anal ysis\%20assumptions, \%20April\%202013.pdf.

ENS. 2014. New Offshore Wind Tenders in Denmark.

http://www.ens.dk/sites/ens.dk/files/dokumenter/publikationer/downloads/new offshore_wind t enders_in_denmark_final.pdf.

European Commission. 2014. Guidelines on State aid for environmental protection and energy 2014-2020. Brussels, BE. http://eur-lex.europa.eu/legalcontent/EN/TXT/HTML/?uri=CELEX:52014XC0628(01)\&from=EN.

European Wind Energy Association (EWEA). 2015. The European offshore wind industry - key trends and statistics 1st half 2015. Brussels, Belgium. http://www.ewea.org/fileadmin/files/library/publications/statistics/EWEA-European-OffshoreStatistics-H1-2015.pdf.

EWEA. 2015a. The European offshore wind industry - key trends and statistics 2014. Brussels, Belgium. http://www.ewea.org/fileadmin/files/library/publications/statistics/EWEA-EuropeanOffshore-Statistics-2014.pdf.

EWEA. 2015b. The European offshore wind industry - key trends and statistics 1st half 2015. Brussels, Belgium. http://www.ewea.org/fileadmin/files/library/publications/statistics/EWEAEuropean-Offshore-Statistics-H1-2015.pdf.

Farquhar, N. 2011. "Smart from the Start": Bringing Atlantic Offshore Wind to Market." BOEM. http://www.boem.gov/uploadedFiles/BOEM/Renewable_Energy_Program/State_Activities/DOII nitiatives032411.pdf

Funk, John. (2015a). "LEEDCo begins taking core samples of Lake Erie bottom core samples." August 27, 2015. The Plain Dealer. http://www.cleveland.com/business/index.ssf/2015/08/leedco_begins_taking_core_samp.html.

Funk, John. (2015b). "Lake Erie wind turbines would cost less with new European invention." June 2, 2015. The Plain Dealer.

http://www.cleveland.com/business/index.ssf/2015/06/lake erie wind turbines would.html. 
Federal Register. 2014. Notice of Determination of No Competitive Interest for the WindFloat Pacific Project Offshore Oregon; MMAA104000. U.S. Department of the Interior. Accessed August 2015. http://www.boem.gov/Wind-Float-Pacific-DNCI/.

Freshfields Bruckhaus Deringer. 2014. European offshore wind 2014: Financing the Opportunities.

http://www.freshfields.com/uploadedFiles/SiteWide/News Room/Insight/Windfarms/Windfarms 2014/Offshore $\% 20$ wind $\% 20$ report $\% 202014$.pdf.

General Electric. "GE Strategic Transformation Accelerating.” September 8, 2015. Accessed September 2015. https://www.genewsroom.com/press-releases/ge-strategic-transformationaccelerating-281631/.

Geiger, Jacob. "Dominion says off-shore wind project could cost far more than expected." Richmond Times-Dispatch. April 23, 2015. Accessed August 2015.

http:/www.richmond.com/business/local/article babe7669-ac56-5fd3-9622-891563adbc74.html

Grandum, Svein, Ishihara, Yoshi. 2015. An overview/status on offshore wind situation in Japan. Innovation Norway-Tokyo.

http://www.norcowe.no/doc/konferanser/2014/Presentasjonar\%20SMI\%20Bergen/Grandum $\% 20$ at $\% 20$ NORCOWE\%20140909.pdf.

Greenacre, Phillip, Gross, Robert, and Heptonstall, Phil. 2010. Great Expectations: The cost of offshore wind in UK waters - understanding the past and projecting the future. UK Energy Research Centre. https://spiral.imperial.ac.uk/bitstream/10044/1/12649/6/Great $\% 20$ Expectations $\% 20$ $\% 20$ The $\% 20$ cost $\% 20$ of $\% 20$ offshore $\% 20$ wind $\% 20 \mathrm{in} \% 20 \mathrm{UK} \% 20$ waters.pdf.

Guillet, Jérôme. "Financing offshore wind - the debt market." Green Giraffe. Presented at EWEA Offshore 2015, Copenhagen, March 12, 2015. http://green-giraffe.eu/sites/greengiraffe.eu/files/150305 ewea_offshore_cph.pdf.

Hamilton, Bruce, Bielecki, Mark, Bloch, Charlie, Decker, Terese, Frantzis, Lisa, Midura, Kirsten, Paidipati, Jay, Zhao, Feng. 2014. Offshore Wind Market and Economic Analysis 2014 Annual Market Assessment. Navigant Consulting, Inc., Burlington, Massachusetts. Prepared for the U.S. Department of Energy.

http://energy.gov/sites/prod/files/2014/09/f18/2014\%20Navigant $\% 20$ Offshore $\% 20 \mathrm{Wind} \% 20 \mathrm{Mar}$ ket $\% 20 \% 26 \% 20$ Economic $\% 20$ Analysis.pdf.

Hamilton, Bruce, Bielecki, Mark, Bloch, Charlie, Decker, Terese, Frantzis, Lisa, Midura, Kirsten, Paidipati, Jay, Zhao, Feng. 2013a. Offshore Wind Market and Economic Analysis Annual Market Assessment. Navigant Consulting, Inc., Burlington, Massachusetts. http://energy.gov/sites/prod/files/2014/08/f18/2012\%20Offshore $\% 20 \mathrm{Wind} \% 20 \mathrm{Market} \% 20 \% 26$ \%20Economic\%20Analysis.pdf. 
Hamilton, Bruce, Battenberg, Lindsay, Bielecki, Mark, Bloch, Charlie, Decker, Terese, Frantzis, Lisa, Paidipati, Jay, Wickless, Andy, Zhao, Feng. 2013b. Offshore Wind Market and Economic Analysis Annual Market Assessment. Navigant Consulting, Inc., Burlington, Massachusetts. http://energy.gov/sites/prod/files/2014/08/f18/2013\%20Offshore \%20Wind $\% 20$ Market $\% 20 \% 26$ $\%$ 20Economic\%20Analysis.pdf.

High Wind. (undated). “Commercialisation of the Boom Lock.” Accessed August 2015. http://www.high-wind.eu/press-release-commercialisation-boom-lock/.

Hobohm, Jens, Krampe, Leonard, Peter, Frank, Gerken, Andree, Heinrich, Peter, Richter, Maik. 2013. Cost Reduction Potentials of Offshore Wind Power in Germany. Prognos AG and The Fichtner Group. http://www.offshore-stiftung.com/60005/Uploaded/SOW Download\%7CStudy LongVersion CostReductionPotentialsofOffshoreWindPowerinGermany.pdf.

Hopper, Abigal Ross. Cape Wind Lease Suspension Order. U.S. Department of the Interior. Bureau of Ocean Energy Management. July 24, 2015. http://www.boem.gov/Lease-Suspension$\underline{\text { Order/. }}$

Hopson, Christopher. "ScottishPower, Vattenfall go their separate ways on East Anglia." August 7, 2015. ReCharge News. London. Accessed August 2015.

http://www.rechargenews.com/incoming/1408067/scottishpower-vattenfall-go-their-separateways-on-east-anglia.

Hu, Ssu-yuan. 2012. "Policy and Promotion of Offshore Wind Power in Taiwan.” Industrial Technology Research Institute. Bureau of Energy.

http://www.re.org.tw/Files/file/01\%20\%E5\%8F\%B0\%E7\%81\%A3\%E9\%9B\%A2\%E5\%B2\%B8 \%Е9\%A2\%A8\%Е9\%9B\%BB\%E6\%94\%BF\%E7\%AD\%96\%E6\%8E\%A8\%E5\%8B\%95.pdf.

Husted, Simon. "LEEDco partners with European firm for offshore wind energy farming." June 3, 2015. The Morning Journal. 2015. Accessed August 2015.

http://www.morningjournal.com/general-news/20150602/leedco-partners-with-european-firmfor-offshore-wind-energy-farming.

Jacquemin, Jerome, Butterworth, Dan, Garret, Chris, Baldock, Nick, Henderson, Andrew. 2011. Inventory of location specific wind energy cost. Intelligent Energy Europe.

EIE/07/759/S12.499460. Accessed August 2015. http://www.windspeed.eu/media/publications/WINDSPEED_D2_2_revised_May_2011.pdf.

Jenkins, Jesse. "New Maryland Legislation Will Drive Offshore Wind Energy Development." March 11, 2013. The Energy Collective. Accessed August 2015. http://www.theenergycollective.com/jessejenkins/196881/offshore-wind-energy-developmentnew-maryland-legislation. 
Jianxiang, Yang. "Analysis: China to reevaluate offshore in new five-year plan." Windpower Offshore. June 16, 2015. Accessed August 2015.

http://www.windpoweroffshore.com/article/1351718/analysis-china-reevaluate-offshore-newfive-year-plan.

Johnson, Tom. "BPU Wants to Hire Outside Expert to Help Breathe Some Life into Offshore Wind." August 14, 2015. NJ Spotlight. http://www.njspotlight.com/stories/15/08/13/bpu-wantsto-hire-outside-expert-to-help-breathe-some-life-into-offshore-wind/.

Juul, Christian. 2014. "Cost reduction - Road to 40\% reduction in CoE." DONG Energy. http://hubnorth.webcamp01.com/wp-content/uploads/2014/06/vindmolleindustrien-konference2-juni-2014 de-indlaeg-v1.pdf.

Kempton, Willet. 2015. Saving Time and Money with Integrated Design and Policy. Greenpower 2015, Boston, Panel: Technical lessons from 20 years of EU experience. University of Delaware College of Earth, Ocean, \& Environment.

Kessler, Richard. "Massachusetts bill mandates utilities buy offshore wind power." Recharge News. January 23, 2015. Accessed August 2015.

http://www.rechargenews.com/wind/1389306/massachusetts-bill-mandates-utilities-buyoffshore-wind-power.

Korea Environmental Industry \& Technology Institute. 2013. "Establishment of a Large-Scale Offshore Wind Farm in the South-west Coast." Accessed August 2015. http://www.eiskorea.org/03_Business/02_Report down.asp?schMenuCode=MB200\&schTabCo $\mathrm{de}=\& \operatorname{strIdx}=886 \& \operatorname{strFileIdx}=1 \&$ schCom $=\&$ schSearch $=\&$ intPage $=1$.

Kuffner, Alex. (2015a). "Giant crane arrives off Block Island to install first foundation for offshore wind farm.” July 18, 2015. The Providence Journal. Providence, Rhode Island. Accessed August 2015. http://www.providencejournal.com/article/20150718/NEWS/150719266.

Kuffner, Alex. (2015b). "Deepwater Wind completes financing for Block Island wind farm." March 2, 2015. The Providence Journal. Providence, Rhode Island. Accessed August 2015. http://www.providencejournal.com/article/20150302/News/150309845/?Start=2.

Lacal Arántegui, Roberto, and Serrano González, Javier. 2015. 2014 JRC wind status report. European Commission Joint Research Center. Brussels, Belgium. http://publications.jrc.ec.europa.eu/repository/bitstream/JRC96184/reqno_jrc96184_2014\%20jrc \%20wind\%20status\%20report\%20-\%20online\%20version.pdf.

Lake Erie Energy Development Corporation (LEEDCo). "Icebreaker Offshore Wind Project to Incorporate New Foundation Design.” June 2, 2015. Accessed August 2015. http://www.leedco.org/press-releases/icebreaker-offshore-wind-project-to-incorporate-newfoundation-design. 
Lee, Andrew. (2015a). "PISA shows scope for foundation steel savings, says Dong." September 1, 2015. ReCharge News. London. Accessed August 2015.

http://www.rechargenews.com/wind/1410097/pisa-shows-scope-for-foundation-steel-savingssays-dong.

Lee, Andrew. (2015b). "Vattenfall wins race for Denmark's 400MW Horns Rev 3." February 27, 2015. ReCharge News. London. Accessed August 2015.

http:/www.rechargenews.com/wind/1393046/vattenfall-wins-race-for-denmarks-400mw-hornsrev-3.

Lee, Andrew. (2015c). "UK offers CfD support to East Anglia, Neart na Gaoithe." February 26, 2015. ReCharge News. London. Accessed August 2015.

http://www.rechargenews.com/wind/1392765/uk-offers-cfd-support-to-east-anglia-neart-nagaoithe.

Lee, Andrew. (2015d). "UK in new raid on renewables as onshore wind airs grievances." July 9, 2015. ReCharge News. London. Accessed August 2015.

http://www.rechargenews.com/wind/1405619/uk-in-new-raid-on-renewables-as-onshore-windairs-grievances.

Maine Aqua Ventus. (2014). “Maine Aqua Ventus I term sheet gains MPUC approval.” January 14, 2014. Accessed August 2015. http://maineaquaventus.com/index.php/newsfeed.

Mainstream Renewable Power. 2014. Neart na Gaoithe Offshore Wind Farm Supply Chain Plan. https://www.gov.uk/government/uploads/system/uploads/attachment_data/file/429410/UK021701-005-MRP-SUPPLY CHAIN PLAN-RPT-A2 - final redaction applied.pdf.

Maples, Ben, Saur, Genevieve, Hand, Maureen, van de Pieterman, Rene, Obdam, Tom. 2013. Installation, Operation, and Maintenance Strategies to Reduce the Cost of Offshore Wind Energy. NREL. NREL/TP-5000-57403. Accessed August 2015.

http://www.nrel.gov/docs/fy13osti/57403.pdf.

Maritime Executive. 2015. "Construction Begins On First Offshore Transfer Vessel For U.S." Accessed August 2015. http://www.maritime-executive.com/article/construction-beings-on-firstoffshore-transfer-vessel-for-us.

McClellan, Stephanie, Ozkan, Deniz, Kempton, Willett, Levitt, Andrew, Thomson, Heather. 2015. New York Offshore Wind Cost Reduction Study. University of Delaware Special Initiative on Offshore Wind. http://www.ceoe.udel.edu/File\%20Library/About/SIOW/New-YorkOffshore-Wind-Cost-Reduction-Study-ff8-2.pdf.

Milborrow, D. "Wind Economics: Making sense of European offshore tariffs." April 30, 2015. Windpower Monthly. http://www.windpowermonthly.com/article/1345433/wind-economicsmaking-sense-european-offshore-tariffs.

Moné, Christopher, Smith, Aaron, Maples, Ben, Hand, Maureen. 2015. 2013 Cost of Wind Energy Review. NREL/TP-5000-63267. Golden, CO: National Renewable Energy Laboratory. http://www.nrel.gov/docs/fy15osti/63267.pdf. 
Musial, Walter, Ram, Bonnie. 2010. Large-Scale Offshore Wind Power in the United States. NREL/TP-500-40745. National Renewable Energy Laboratory, Golden, CO (US).

http://www.nrel.gov/wind/pdfs/40745.pdf.

Musial, Walter, Elliott, Dennis, Fields, Jason, Parker, Zachary, Scott, George, Draxl, Caroline. 2013a. Assessment of Offshore Wind Energy Leasing Areas for the BOEM Maryland Wind Energy Area. NREL/TP-5000-58562. National Renewable Energy Laboratory, Golden, CO (US). http://www.nrel.gov/docs/fy130sti/58562.pdf.

Musial, Walter, Elliott, Dennis, Fields, Jason, Parker, Zachary, Scott, George, Draxl, Caroline. 2013b. Assessment of Offshore Wind Energy Leasing Areas for the BOEM New Jersey Wind Energy Area. NREL/TP-5000-60403. National Renewable Energy Laboratory, Golden, CO (US). http://www.nrel.gov/docs/fy13osti/60403.pdf.

Mrick, Steve. "Vineyard Power and corporate partner win offshore wind lease." Martha's Vineyard Times. February 4, 2015. Accessed August 2015. http://www.mvtimes.com/2015/02/04/vineyard-power-corporate-partner-win-offshore-windlease/.

National Grid. 2014. UK Future Energy Scenarios. http://fes.nationalgrid.com/media/1071/2014fes.pdf.

NJ Senate Bill 2711. State of New Jersey 216th Legislature. January 15, 2015. http://www.njleg.state.nj.us/2014/Bills/S3000/2711_I1.PDF.

North American Windpower. (2015a). “Carper, Collins Reintroduce Offshore Wind Bill.” July 10, 2015. Accessed August 2015.

https://www.nawindpower.com/e107_plugins/content/content.php?content.14406.

North American Windpower. (2015b). "Wanting 'A Seat at the Table,' Erie County, Pa. Joins LEEDCo.” April 21, 2015. Accessed August 2015.

http://www.nawindpower.com/e107_plugins/content/content.php?content.14145.

Offshore Aberdeen. "Low oil price switches offshore focus to renewable projects." (2015). North Business Media. Aberdeen. Accessed August 2015. http://www.offshoreaberdeen.com/focus/low-oil-price-switches-offshore-focus-to-renewableprojects,offshore-aberdeen.

ORE Catapult. 2015. Cost Reduction Monitoring Framework: Summary Report to the Offshore Wind Programme Board.

https://ore.catapult.org.uk/documents/10619/110659/ORE+Catapult+report+to+the+OWPB/a8c7 3f4e-ba84-493c-8562-acc87b0c2d76.

Oregon.gov. "Governor Brown Announces Advisory Group to Boost State Economy While Expanding Access to Renewable Energy.” August 26, 2015. Accessed August 2015. http://www.oregon.gov/newsroom/Pages/NewsDetail.aspx?newsid=783. 
Orrell, Alice, and Foster, Nikolas. 2015. 2014 Distributed Wind Market Report. Pacific Northwest National Laboratory. PNNL-24460. Accessed September 2015. http://www.energy.gov/sites/prod/files/2015/08/f25/2014-Distributed-Wind-Market-Report8.7 0.pdf.

ORE Catapult and The Crown Estate. 2014. SPARTA: The performance data exchange platform for offshore wind. https://ore.catapult.org.uk/documents/10619/106434/SPARTA/66bd6331a17e-430f-b7ad-1c908eeef6da.

Principle Power, Inc. WindFloat Pacific Project Overview. 2015. Accessed August 2015. http://windfloatpacific.com/about/.

PricewaterhouseCoopers. 2012. Offshore wind cost reduction pathways study - Finance work stream. The Crown Estate. London. http://www.thecrownestate.co.uk/media/451398/ei-km-inpe-cost-052012-offshore-wind-cost-reduction-pathways-finance-workstream.pdf.

Prinsen, Bob. (2015). International Comparison Level Offshore Wind. Ecofys. Commissioned by TKI Wind Op Zee. Presented at IEA Wind Task 26 Workshop. Copenhagen, Denmark.

Radowitz, Bernd. "Siemens nails 600MW Gemini deal." (2014). RECharge News. Berlin. Accessed August 2015. http://www.rechargenews.com/wind/offshore/1362118/Siemens-nails600MW-Gemini-deal.

Radowitz, Bernd. "Siemens sees DC offshore transformer module next year." (2015). RECharge News. Hamburg. Accessed August 2015. http://www.rechargenews.com/wind/1398901/siemenssees-dc-offshore-transformer-module-next-year.

Ramboll. "Ramboll Delivers Unprecedented Substation Design for Hornsea One." March 11, 2015. Accessed August 2015. http://www.ramboll.com/media/rgr/ramboll-deliversunprecedented-substation-design-for-hornsea-one.

RENews “Baryonyx quits U.S. Offshore.” February 6, 2014. http://renews.biz/67568/baryonyxquits-us-offshore/.

Recharge News. "Wind Power Deals \& Company News.” April 20, 2015. Accessed August 2015. http:/www.rechargenews.com/wind/1397505/wind-power-deals-and-company-news.

Schwartz, Marc, Heimiller, Donna, Haymes, Steve, Musial, Walt. 2010. Assessment of Offshore Wind Energy Resources for the United States. NREL/TP-500-45889. National Renewable Energy Laboratory, Golden, CO (US). http://www.nrel.gov/docs/fy10osti/45889.pdf.

Sen, Arijit. "2015 New York State Energy Plan - a Great First Step Towards Being a Game Changer." July 17, 2015. Columbia Law School Sabin Center for Climate Change Law. Accessed August 2015. http://blogs.law.columbia.edu/climatechange/2015/07/17/2015-newyork-state-energy-plan-a-great-first-step-towards-being-a-game-changer/. 
Sheldrick, Aaron, and Kato, Issei. "Japan restarts reactor in test of Abe's nuclear policy." August 11, 2015. Rueters. Accessed August 2015. http://www.reuters.com/article/2015/08/11/us-japannuclear-restarts-idUSKCN0QF0YW20150811.

Siemens. "Lifting Mechanism for Mounting Huge Rotor Blades." September 24, 2014. Accessed August 2015.

http://www.siemens.com/press/en/presspicture/?press=/en/presspicture/innovationnews/2014/in2 $\underline{0140905-02 . h t m}$.

Smith, Patrick. (2014a). “Question of the week: Do we need a 10MW turbine?” June 9, 2014. Windpower Monthly. Accessed August 2015.

http://www.windpowermonthly.com/article/1297819/question-week-need-10mw-turbine.

Smith, Patrick. (2014b). "Dong contracts SPT for substation suction foundations." Windpower Offshore. May 22, 2014. Accessed August 2015.

http://www.windpoweroffshore.com/article/1295464/dong-contracts-spt-substation-suctionfoundations.

Smith, Patrick. (2014c). "Costs force ABB to abandon offshore converter work.” Windpower Offshore. November 19, 2014. Accessed August 2015.

http://www.windpoweroffshore.com/article/1322618/costs-force-abb-abandon-offshoreconverter-work.

Snieckus, Darius and Lee, Andrew. (2015). "Areva-Gamesa tie-up seeks 20\% market share." EWEA OFFSHORE COPENHAGEN 2015. http://www.ewea.org/offshore2015/wpcontent/uploads/EWEA-Offshore-2015-Day2.pdf.

Snieckus, Darius. (2014). "IN DEPTH: How gravity can bring down offshore costs." December 2, 2104. RECharge News. London. Accessed August 2015.

http://www.rechargenews.com/wind/europe_africa/1385197/IN-DEPTH-How-gravity-can-bringdown-offshore-costs.

Snieckus, Darius. (2015a). "SPT Offshore to deploy suction-pile foundation at Dudgeon." May 21, 2015. RECharge News. London. Accessed August 2015.

http://www.rechargenews.com/wind/1400547/spt-offshore-to-deploy-suction-pile-foundation-atdudgeon.

Snieckus, Darius. (2015b). "Universal Foundation on cusp of Denmark deal.” April 20, 2015. RECharge News. Frederickshavn, Denmark. Accessed August 2015.

http://www.rechargenews.com/wind/1397553/universal-foundation-on-cusp-of-denmark-deal.

Snieckus, Darius. (2015c). "Siemens puts giant service vessel to work." EWEA OFFSHORE COPENHAGEN 2015. http://www.ewea.org/offshore2015/wp-content/uploads/EWEAOffshore-2015-Day1.pdf.

Steel, William. "Denmark issues call for offshore prototypes. ”August 7, 2015. Windpower Off shore. Accessed August 2015. http://www.windpoweroffshore.com/article/1359216/denmarkissues-call-offshore-prototypes. 
Steiner-Dicks, Katherine. "Policy uncertainty biggest threat to France's 2030 renewable targets and long awaited offshore wind plans." February 19, 2015. Wind Energy Update. Accessed August 2014. http://analysis.windenergyupdate.com/offshore-wind/policy-uncertainty-biggestthreat-frances-2030-renewable-targets-and-long-awaited.

Stridbaek, U. (2015). Offshore wind is getting cheaper. DONG Energy. Presented March 23, 2015. https://costing.irena.org/media/9984/Ulrik_Stridbaek_DongEnergy_Cost\%20reduction\%20poten tials $\% 20$ for $\% 20$ offshore $\% 20$ wind.pdf.

Stromsta, Karl-Erik. (2015a). "IN DEPTH: Block Island is finally moving from dream to reality." May 7, 2015. Recharge News. Accessed August 2015. http://www.rechargenews.com/wind/1398218/in-depth-block-island-is-finally-moving-fromdream-to-reality.

Stromsta, Karl-Erik. (2015b). "Deepwater sees PPA for ONE in '12-18 months'." August 4, 2015. Recharge News. Accessed August 2015. http://www.rechargenews.com/wind/1407667/deepwater-sees-ppa-for-one-in-12-18-months.

Stromsta, Karl-Erik. (2015c). "Renexia plans 500MW US offshore." October 8, 2014. Recharge News. Accessed August 2015. http://www.rechargenews.com/wind/1379488/Renexia-plans500MW-US-offshore.

Subsea World News. "EDF-Led Consortium Needs Supplier of Gravity-Based Foundations for French OWF." May 23, 2014. Accessed August 2015. http://subseaworldnews.com/2014/05/23/edf-led-consortium-needs-supplier-of-gravity-basedfoundations-for-french-owf/.

Tavares, Isaac, Brennan, Feargal. "The SLIC Project: Advancing Fatigue Design Guidance \& Standards for Offshore Wind. Centrica and Cranfield University. Presented at EWEA Offshore 2015, Copenhagen, March 10-12, 2015.

http://www.ewea.org/offshore2015/conference/allposters/PO081.pdf.

Tegen, Suzanne, Hand, Maureen, Maples, Ben, Lantz, Eric, Schwabe, Paul, Smith, Aaron. 2012. The 2010 Cost of Wind Energy Review. NREL TP-5000-52920. Golden, CO: National Renewable Energy Laboratory. http://www.nrel.gov/docs/fy12osti/52920.pdf.

Tegen, Suzanne, Lantz, Eric, Hand, Maureen, Maples, Ben, Smith, Aaron, Schwabe, Paul. 2013. 2011 Cost of Wind Energy Review. NREL TP-5000-56266 Golden, CO: National Renewable Energy Laboratory. http://www.nrel.gov/docs/fy13osti/56266.pdf.

TenneT. 2014. "TenneT awards twelfth offshore grid connection for wind farms in the German part of the North Sea." April 15, 2014. Accessed August 2015. http://www.tennet.eu/nl/news/article/tennet-awards-twelfth-offshore-grid-connection-for-windfarms-in-the-german-part-of-the-north-sea.html. 
The Crown Estate. 2012. Offshore Wind Cost Reduction Pathways Study.

http://www.thecrownestate.co.uk/media/5493/ei-offshore-wind-cost-reduction-pathwaysstudy.pdf.

The Crown Estate. "Pioneering SPARTA system for offshore wind farms goes live." July 1, 2015. London. Accessed August 2015. http://www.thecrownestate.co.uk/news-andmedia/news/2015/pioneering-sparta-system-for-offshore-wind-farms-goes-live/.

The White House. "Fact Sheet: President Obama to Announce Historic Carbon Pollution Standards for Power Plants." August 3, 2015. Office of the Press Secretary. Accessed August 2015. https://www.whitehouse.gov/the-press-office/2015/08/03/fact-sheet-president-obamaannounce-historic-carbon-pollution-standards.

TKI Wind Op Zee. (2013). "How Dutch innovations support 40\% cost price reduction." http://tki-windopzee.eu/files/2014-09/General\%20Presentation\%20TKI\%20Wind\%20op\%20 $\underline{\text { Zee} \% 20(3) . p d f .}$

UK Energy Research Center. (2010). Great Expectations: The cost of offshore wind in UK waters - understanding the past and projecting the future. UK Energy Research Centre. ISBN 1 90314409 4. http://www.ukerc.ac.uk/publications/great-expectations-the-cost-of-offshore-windin-uk-waters-understanding-the-past-and-projecting-the-future.html.

United States Department of Agriculture (USDA). "Economic Research Service." (2015). Accessed August 2015. http://www.ers.usda.gov/data-products/agricultural-exchange-rate-dataset.aspx.

University of Maine. (2015). "Our Research - VolturnUS 1:8." University of Maine Advanced Structures and Composites Center. Accessed August 2015. https://composites.umaine.edu/ourresearch/volturnus/.

Valpy, Bruce, English, Philip, Martínez, Antoni, Simonot, Emilien. 2014. Future renewable energy costs: offshore wind. BVG Associates and KIC InnoEnergy. http:/www.kicinnoenergy.com/wp-content/uploads/2014/09/KIC IE OffshoreWind anticipated innovations impact1.pdf.

van de Pieterman, Rene, Braam, Henk, Obdam, Tom, Rademakers, Luc, van der Zee, T. (2011). "Optimisation of maintenance strategies for offshore wind farms." Energy research Centre of the Netherlands. Presented at the Offshore 2011 Conference. November 29-December 1, 2011. Accessed August 2015. http://www.ecn.nl/docs/library/report/2011/m11103.pdf.

Vattenfall and ScottishPower Renewables. (2014). East Anglia ONE Offshore Windfarm Supply Chain Plan. UK Department of Energy and Climate Change. https:/www.gov.uk/government/uploads/system/uploads/attachment_data/file/429411/EA1_SC plan_600MW_DECC_Shortened 19.3.15.pdf.

Vestas. (2013). Vestas and Mitsubishi Heavy Industries form a joint venture dedicated to offshore wind energy. September 27, 2013. Vestas Wind Systems A/S. Aarhus, Denmark. http://vestas.com/en/media/ /media/c25bb62b1a6d4d0d8a8873a36597fb46.ashx. 
Vitina, Aisma. Lüers, Silke, Wallasch, Anna-Kathrin, Berkhout, Volker, Duffy, Aidan, Cleary, Brendan, Husabø, Leif, Weir, David, Lacal-Arántegui, Roberto, Hand, Maureen, Lantz, Eric, Belyeu, Kathy, Wiser, Ryan, Bolinger, Mark, Hoen, Ben. 2015. IEA Wind Task 26: Wind Technology, Cost, and Performance Trends in Denmark, Germany, Ireland, Norway, the European Union, and the United States: 2007-2012. International Energy Agency. http://ieawind.org/task 26 public/PDF/IEA\%20Wind\%20Task\%2026\%20WP1\%20Report $\% 206$ 4332.pdf.

Wagner, Lorry. 31 August 2015. LEEDCo. Email Correspondence.

Watanabe, Chisaki. "MHI Vestas Set to Challenge Siemens With Largest Wind Turbine." March 30, 2015. Bloomberg Business. Accessed August 2015.

http://www.bloomberg.com/news/articles/2015-03-31/mhi-vestas-set-to-challenge-siemens-withlargest-wind-turbine.

Webb, Alex and De Beaupuy, Francois. "Siemens Missing Profit Estimate Shows Alstom TieUp Risk.” May 7, 2014. Bloomberg Business. Accessed August 2014.

http:/www.bloomberg.com/news/articles/2014-05-07/siemens-profit-misses-estimates-on-morepower-charges.

Weston, David. (2014a). "Vestas "V200 10MW turbine” application revealed.” July 7, 2014. Windpower Offshore. Accessed August 2015. http://www.windpoweroffshore.com/article/1302319/vestas-v200-10mw-turbine-applicationrevealed.

Weston, David. (2014b). "Gallery: Lightweight offshore foundations installed.” December 12, 2014. Windpower Monthly. Accessed August 2015.

http://www.windpowermonthly.com/article/1326269/gallery-lightweight-offshore-foundationsinstalled.

Weston, David. (2014c). “Gicon floating foundation construction underway.” July 24, 2014. Windpower Offshore. Accessed August 2015. http://www.windpoweroffshore.com/article/1305260/gicon-floating-foundation-constructionunderway.

Weston, D. (2015a). “Denmark seeks nearshore contractors for 350MW.” February 23, 2015. Windpower Offshore. http://www.windpoweroffshore.com/article/1335062/denmark-seeksnearshore-contractors-350mw.

Weston, David. (2015b). "Taiwan boosts offshore ambition." August 18, 2015. Windpower Offshore. Accessed August 2015. http://www.windpoweroffshore.com/article/1360496/taiwanboosts-offshore-ambition.

Weston, David. (2015c). "Seatower gravity-base foundation installed." February 9, 2015. Windpower Offshore. Accessed August 2015.

http://www.windpoweroffshore.com/article/1333039/seatower-gravity-base-foundation-installed. 
Wheeler, Timothy. "Planning for Md. offshore wind project gets underway." June 20, 2015. The Baltimore Sun. Accessed August 2015. http://www.baltimoresun.com/features/green/blog/bsmd-offshore-wind-20150619-story.html\#page=1.

Willow, Chris, and Valpy, Bruce. 2015. Approaches to cost-reduction in offshore wind. BVG Associates. Committee on Climate Change. Accessed August 2015.

https://www.theccc.org.uk/wp-content/uploads/2015/06/BVG-Associates-2015-Approaches-tocost-reduction-in-offshore-wind.pdf.

Windpower Monthly. "EWEA Offshore: India could have offshore wind by 2019." March 12, 2015. Accessed August 2015. http://www.windpowermonthly.com/article/1337919/eweaoffshore-india-offshore-wind-2019.

Wiser, Ryan and Bollinger, Mark. 2015. 2014 Wind Technologies Market Report. Lawrence Berkeley National Laboratory. U.S. Department of Energy Office of Energy Efficiency \&Renewable Energy. DOE/GO-102015-4702.

http://energy.gov/sites/prod/files/2015/08/f25/2014-Wind-Technologies-Market-Report-8.7.pdf 


\section{Appendix A. U.S. Offshore Wind Projects: Under Construction and Approved}

Table A-1. U.S. Offshore Wind Projects Currently Under Construction or Approved

\begin{tabular}{|c|c|c|}
\hline \multicolumn{2}{|c|}{ Project: Block Island Wind Farm (BIWF) } & \multirow{12}{*}{$\begin{array}{l}\text { Status } \\
\text { Deepwater Wind reached financial close for the BIWF in March } 2015 \text {. The } \\
\text { project is currently under construction: five jacket foundations will be } \\
\text { installed in summer 2015; the } 34.5-k i l o v o l t \text { cable connecting Block Island to } \\
\text { the mainland will be installed in spring 2016, and the five } 6-\mathrm{MW} \text { direct-drive } \\
\text { turbines (Alstom) will be installed in summer } 2016 \text {. This project is now } \\
\text { expected to be the first operating offshore wind project in the United States. }\end{array}$} \\
\hline Developer & Deepwater Wind & \\
\hline State & Rhode Island & \\
\hline Jurisdiction & State & \\
\hline Status & Under Construction & \\
\hline Capacity (MW) & 30 & \\
\hline Turbines (\#) & 5 & \\
\hline Average Distance to Shore (km) & 4.5 & \\
\hline Average Water Depth $(\mathrm{m})$ & 26 & \\
\hline Turbine Rating (MW) & 6 & \\
\hline Foundation Type & Four-Legged Jacket & \\
\hline Target COD & 2016 & \\
\hline \multicolumn{2}{|c|}{ Project: Fishermen's Atlantic City Windfarm } & Status \\
\hline Developer & Fishermen's Energy & \multirow{11}{*}{$\begin{array}{l}\text { Fishermen's Atlantic City Windfarm is one of three Advanced Technology } \\
\text { Demonstration projects selected by the U.S. Department of Energy to } \\
\text { receive up to } \$ 47 \text { million in federal funding. The project has all of the } \\
\text { permits necessary to proceed with construction and is looking to secure } \\
\text { offshore renewable energy certificates from the State of New Jersey. The } \\
\text { New Jersey Board of Public Utilities (BPU) has twice rejected Fishermen's } \\
\text { Energy's proposal citing insufficient public benefit, a decision that was } \\
\text { upheld by the Appellate Division of the Superior Court of New Jersey in May } \\
2015 . \text { The company is appealing this decision to the New Jersey State } \\
\text { Supreme Court. In parallel, the New Jersey State Senate passed a bill in } \\
\text { February } 2015 \text { that would force the BPU to award offshore renewable } \\
\text { energy certificates to a project that is a '...nominal } 20 \text { MW and no more } \\
\text { than } 25 \text { MW in nameplate capacity' and located '.... offshore of a municipality } \\
\text { in which casino gaming is authorized.' The bill now goes to the State } \\
\text { Assembly and must be signed by Governor Chris Christi. }\end{array}$} \\
\hline State & New Jersey & \\
\hline Jurisdiction & State & \\
\hline Status & Approved & \\
\hline Capacity (MW) & 24 & \\
\hline Turbines (\#) & 6 & \\
\hline Average Distance to Shore $(\mathrm{km})$ & 4.5 & \\
\hline Average Water Depth (m) & 12 & \\
\hline Turbine Rating (MW) & 4.0 & \\
\hline Foundation Type & $\begin{array}{c}\text { Inward Battered Guided } \\
\text { Structure Jacket }\end{array}$ & \\
\hline Target COD & 2017 & \\
\hline
\end{tabular}




\begin{tabular}{|c|c|c|}
\hline \multicolumn{2}{|l|}{ Project: Cape Wind Offshore } & \multirow{2}{*}{ Status } \\
\hline Developer & $\begin{array}{l}\text { Energy Management } \\
\text { Incorporated }\end{array}$ & \\
\hline State & Massachusetts & \multirow{6}{*}{$\begin{array}{l}\text { Cod, was poised to be the first commercial wind plant in the United States, } \\
\text { with construction originally scheduled to begin in May 2015; however, } \\
\text { National Grid and EVERSOURCE (formerly NSTAR) delivered notices of } \\
\text { cancellation of Cape Wind's PPAs in January } 2015 \text { after a milestone to } \\
\text { obtain financing, start construction, or submit financial collateral was } \\
\text { allegedly not met. Cape Wind contests the lawfulness and effect of such } \\
\text { notices and believes that the milestones were extended pursuant to the } \\
\text { terms of the agreements, citing extensive legal battles that could not be } \\
\text { predicted when the contract was executed, and is expected to challenge the } \\
\text { decision. }\end{array}$} \\
\hline Jurisdiction & Federal & \\
\hline Status & Approved & \\
\hline Capacity (MW) & 468 & \\
\hline Turbines (\#) & 130 & \\
\hline Average Distance to Shore (km) & 13 & \\
\hline Average Water Depth (m) & 10 & \multirow{4}{*}{$\begin{array}{l}\text { Cape Wind was originally scheduled to start construction on May 1, 2015, } \\
\text { but filed a request with the Massachusetts Energy Facilities Siting Board to } \\
\text { extend the deadline by } 2 \text { years. BOEM also approved Cape Wind's request } \\
\text { for a 2-year suspension of the operations term of its lease, although the } \\
\text { developer remains responsible for annual lease payments }\end{array}$} \\
\hline Turbine Rating (MW) & 3.6 & \\
\hline Foundation Type & Monopile & \\
\hline Target COD & 2018 & \\
\hline
\end{tabular}




\section{Appendix B. U.S. Offshore Wind Projects: Major Permits Submitted}

Table B-1. U.S. Offshore Wind Projects That Have Submitted Major Permits

\begin{tabular}{|c|c|c|}
\hline \multicolumn{2}{|l|}{ Project: WindFloat Pacific } & \multirow{2}{*}{$\begin{array}{l}\text { Status } \\
\text { WindFloat Pacific is one of three Advanced Technology }\end{array}$} \\
\hline Developer & Principle Power, Inc. & \\
\hline State & Oregon & \multirow{10}{*}{$\begin{array}{l}\text { Demonstration (ATD) projects selected by the U.S. Department of } \\
\text { Energy (DOE) for up to } \$ 47 \text { million in federal funding. The project is } \\
\text { expected to consist of an array of } 6-\text { to } 8-M W \text { turbines installed on } \\
\text { two to three floating WindFloat semisubmersible foundations. } \\
\text { Principle Power has received a determination of no competitive } \\
\text { interest from the Bureau of Ocean Energy Management for its } \\
\text { proposed lease area off the Oregon coast. The bureau is } \\
\text { conducting an environmental assessment, which is expected to be } \\
\text { published in } 2015 \text {. Principle Power is pursuing permits and power } \\
\text { offtake agreements through the WindFloat Pacific Offshore Wind } \\
\text { Advisory Committee announced by Oregon Governor Kate Brown. }\end{array}$} \\
\hline Jurisdiction & Federal & \\
\hline Status & Major Permits Submitted & \\
\hline Capacity (MW) & Up to $25 \mathrm{MW}$ & \\
\hline Turbines (\#) & 6 & \\
\hline Average Distance to Shore (km) & 29 & \\
\hline Average Water Depth $(\mathrm{m})$ & 350 & \\
\hline Turbine Rating (MW) & 6 & \\
\hline Foundation Type & Semisubmersible & \\
\hline Target COD & 2018 & \\
\hline \multicolumn{2}{|c|}{ Virginia Offshore Wind Technology Advancement Project (VOWTAP) } & Status \\
\hline Developer & Dominion Virginia Power & \multirow{11}{*}{$\begin{array}{l}\text { VOWTAP is one of three ATD projects selected by DOE for up to } \\
\$ 47 \text { million in federal funding. The project is at the eastern edge of } \\
\text { Dominion's commercial Virginia lease and includes two Alstom } \\
\text { Haliade } 150-6 \mathrm{MW} \text { turbines on inward battered guided structures. } \\
\text { Dominion is planning to use the experience gained from VOWTAP } \\
\text { to inform its future commercial-scale projects. } \\
\text { Dominion recently announced that the project schedule would be } \\
\text { delayed to } 2018 \text { after the initial bid for construction came in higher } \\
\text { than expected. Dominion and its partners have formed a task force } \\
\text { to study ways to reduce cost. }\end{array}$} \\
\hline State & Virginia & \\
\hline Jurisdiction & Federal & \\
\hline Status & Major Permits Submitted & \\
\hline Capacity (MW) & 12 & \\
\hline Turbines (\#) & 2 & \\
\hline Average Distance to Shore (km) & 42 & \\
\hline Average Water Depth (m) & 25 & \\
\hline Turbine Rating (MW) & 6 & \\
\hline Foundation Type & Inward Battered Guided Structure & \\
\hline Target COD & & \\
\hline
\end{tabular}




\begin{tabular}{|c|c|c|}
\hline \multicolumn{2}{|l|}{ Project: Aqua Ventus I } & \multirow{7}{*}{$\begin{array}{l}\text { Status } \\
\text { The DeepCwind consortium, a public-private partnership led by the } \\
\text { University of Maine and involving more than } 30 \text { industry partners, is } \\
\text { developing the Maine Aqua Ventus I project. The consortium is } \\
\text { proposing to deploy two 6-MW wind turbines on VolturnUS floating } \\
\text { semisubmersible foundations at a site that is located } 3 \mathrm{~km} \text { south of } \\
\text { Monhegan Island. }\end{array}$} \\
\hline Developer & University of Maine & \\
\hline State & Maine & \\
\hline Jurisdiction & State & \\
\hline Status & Major Permits Submitted & \\
\hline Capacity (MW) & 12 & \\
\hline Turbines (\#) & 2 & \\
\hline Average Distance to Shore (km) & 4 & \multirow{5}{*}{$\begin{array}{l}\text { Although the project was not selected for the second phase of the } \\
\text { ATD program, it was awarded } \$ 3 \text { million by DOE to finalize design. }\end{array}$} \\
\hline Average Water Depth $(\mathrm{m})$ & 95 & \\
\hline Turbine Rating (MW) & 6 & \\
\hline Foundation Type & Semisubmersible & \\
\hline Target COD & 2018 & \\
\hline \multicolumn{2}{|l|}{ Project: Icebreaker (Great Lakes) } & Status \\
\hline Developer & $\begin{array}{l}\text { Lake Erie Energy Development } \\
\text { Corporation (LEEDCo) }\end{array}$ & \multirow{11}{*}{$\begin{array}{l}\text { LEEDCo plans to install an 18-MW offshore wind plant in Lake Erie } \\
\text { and would be one of the first in the world to deploy offshore wind } \\
\text { turbines in freshwater with exposure to surface ice. Known as } \\
\text { Icebreaker, this project consists of six 3-MW Siemen's direct-drive } \\
\text { wind turbines at a site that is } 7 \text { miles north of Cleveland. LEEDCo } \\
\text { signed a } 50 \text {-year submerged land lease with the State of Ohio in } \\
2014 \text { and is pursuing permits and power offtake agreements. In } \\
\text { addition, the company has announced strategic partnerships with } \\
\text { suppliers including Siemens and Fred. Olsen Windcarrier. } \\
\text { Although the project was not selected for the second phase of the } \\
\text { ATD program, it was awarded } \$ 3 \text { million by DOE to finalize design. }\end{array}$} \\
\hline State & Ohio & \\
\hline Jurisdiction & State & \\
\hline Status & Major Permits Submitted & \\
\hline Capacity (MW) & 18 & \\
\hline Turbines (\#) & 6 & \\
\hline Average Distance to Shore (km) & 9.1 & \\
\hline Average Water Depth $(\mathrm{m})$ & 18 & \\
\hline Turbine Rating (MW) & 3 & \\
\hline Foundation Type & Suction Bucket & \\
\hline Target COD & 2018 & \\
\hline
\end{tabular}




\section{Appendix C. U.S. Offshore Wind Projects: Planning with Site Control}

Table C-1. U.S. Offshore Wind Projects in the Planning - Site Control Phase

\begin{tabular}{|c|c|c|}
\hline \multicolumn{2}{|l|}{ Project: Deepwater ONE } & \multirow{6}{*}{$\begin{array}{l}\text { Status } \\
\text { Deepwater Wind won the competitive lease auction for the two lease } \\
\text { areas within the Rhode Island and Massachusetts Area of Mutual Interest. } \\
\text { The plan includes a regional transmission system linking Long Island, } \\
\text { New York, to southeastern New England. The developer has announced } \\
\text { that it will begin to survey the lease areas starting in summer } 2015 \text {. }\end{array}$} \\
\hline Developer & Deepwater Wind & \\
\hline State & Rhode Island - Massachusetts & \\
\hline Jurisdiction & Federal & \\
\hline Status & Planning - Site Control & \\
\hline Capacity (MW) & 1,000 & \\
\hline Turbines (\#) & To Be Announced (TBA) & \multirow{6}{*}{$\begin{array}{l}\text { The Long Island Power Authority did not select Deepwater Wind's } 210- \\
\text { MW offshore proposal in its latest tender for } 280 \mathrm{MW} \text { of renewable energy } \\
\text { supply, instead contracting with } 122 \mathrm{MW} \text { of solar. The developer has } \\
\text { indicated that it is working with stakeholders, including policymakers, } \\
\text { regulators, and utilities in Rhode Island and Massachusetts to create } \\
\text { conditions that could lead to a power purchase agreement. }\end{array}$} \\
\hline Average Distance to Shore (km) & 30 & \\
\hline Average Water Depth $(\mathrm{m})$ & 40 & \\
\hline Turbine Rating (MW) & 6 & \\
\hline Foundation Type & Jacket & \\
\hline Target COD & 2020 & \\
\hline \multicolumn{2}{|l|}{ Project: DONG Energy Lease } & Status \\
\hline Developer & DONG Energy & \multirow{11}{*}{$\begin{array}{l}\text { Renewable Energy Systems Americas won the competitive lease auction } \\
\text { for Area OCS-A } 0500 \text { and sold the project development rights to DONG } \\
\text { Energy, a worldwide offshore wind developer. The Bureau of Ocean } \\
\text { Energy Management (BOEM) approved the sale on July } 18,2015 . \\
\text { The lease could support more than } 1 \mathrm{GW} \text { and construction could begin } \\
\text { after } 2020 \text {. }\end{array}$} \\
\hline State & Massachusetts & \\
\hline Jurisdiction & Federal & \\
\hline Status & Planning - Site Control & \\
\hline Capacity (MW) & 1,000 & \\
\hline Turbines (\#) & TBA & \\
\hline Average Distance to Shore (km) & 50 & \\
\hline Average Water Depth $(\mathrm{m})$ & 45 & \\
\hline Turbine Rating (MW) & TBA & \\
\hline Foundation Type & TBA & \\
\hline Target COD & 2022 & \\
\hline \multicolumn{2}{|l|}{ Project: OffshoreMW Lease } & Status \\
\hline Developer & OffshoreMW, Vineyard Power & \multirow{11}{*}{$\begin{array}{l}\text { Martha's Vineyard Offshore Wind Alliance, a partnership between } \\
\text { OffshoreMW and Vineyard Power, won the competitive lease auction for } \\
\text { Lease Area OCS-A 501, approximately } 22 \mathrm{~km} \text { south of Martha's Vineyard. } \\
\text { Early plans call for building a project that is } \sim 400 \mathrm{MW} \text { in size, supplying } \\
\text { Martha's Vineyard with electricity from up to } 100 \mathrm{MW} \text { of the project, and } \\
\text { exporting the balance to the mainland. Martha's Vineyard Offshore Wind } \\
\text { Alliance is a community benefit agreement, which aims to develop a } \\
\text { community-owned wind project that maximizes the benefits of offshore } \\
\text { wind for Martha's Vineyard and Massachusetts. }\end{array}$} \\
\hline State & Massachusetts & \\
\hline Jurisdiction & Federal & \\
\hline Status & Planning - Site Control & \\
\hline Capacity (MW) & 400 & \\
\hline Turbines (\#) & TBA & \\
\hline Average Distance to Shore (km) & 23 & \\
\hline Average Water Depth $(\mathrm{m})$ & 45 & \\
\hline Turbine Rating (MW) & 6 & \\
\hline Foundation Type & TBA & \\
\hline Target COD & 2020 & \\
\hline
\end{tabular}




\begin{tabular}{|c|c|c|}
\hline \multicolumn{2}{|c|}{ Project: Dominion Virginia Power Lease } & \multirow{12}{*}{$\begin{array}{l}\text { Status } \\
\text { Dominion Virginia Power won the competitive lease auction for the } \\
\text { Virginia wind energy area that is located approximately } 50 \mathrm{~km} \text { offshore } \\
\text { Virginia beach. The company plans to develop the zone using a phased } \\
\text { approach, up to a maximum capacity of approximately } 2 \mathrm{GW} \text {. It has hired } \\
\text { Ramboll, a Danish engineering firm, to conduct preliminary design work. }\end{array}$} \\
\hline Developer & Dominion Virginia Power & \\
\hline State & Virginia & \\
\hline Jurisdiction & Federal & \\
\hline Status & Planning - Site Control & \\
\hline Capacity (MW) & 2,000 & \\
\hline Turbines (\#) & TBA & \\
\hline Average Distance to Shore (km) & 50 & \\
\hline Average Water Depth (m) & 30 & \\
\hline Turbine Rating (MW) & 6 & \\
\hline Foundation Type & TBA & \\
\hline Target COD & $2022-2024$ & \\
\hline \multicolumn{2}{|l|}{ Project: Mid-Atlantic Wind Park } & Status \\
\hline Developer & NRG Bluewater & \multirow{11}{*}{$\begin{array}{l}\text { NRG Bluewater received one of the first U.S. offshore leases from BOEM } \\
\text { in October } 2012 \text { as part of its "Smart from the Start" program; however, } \\
\text { Delmarva has since canceled a power purchase agreement for } 200 \mathrm{MW} \\
\text { of the power. After announcing that the project was officially on hold in } \\
2012 \text {, a spokesman for the company stated in } 2013 \text { that NRG will } \\
\text { maintain the lease as it seeks investors or buyers. Although it is unclear } \\
\text { whether the project will be developed or sold, this report considers it to be } \\
\text { in the "planning - site control" phase because the lease between NRG } \\
\text { and BOEM is still active (see Table 1). }\end{array}$} \\
\hline State & Delaware & \\
\hline Jurisdiction & Federal & \\
\hline Status & Planning - Site Control & \\
\hline Capacity (MW) & 450 & \\
\hline Turbines (\#) & 150 & \\
\hline Average Distance to Shore (km) & 17 & \\
\hline Average Water Depth $(\mathrm{m})$ & 20 & \\
\hline Turbine Rating (MW) & TBA & \\
\hline Foundation Type & Monopile & \\
\hline Target COD & TBA & \\
\hline \multicolumn{2}{|l|}{ Project: U.S. Wind Lease } & Status \\
\hline Developer & U.S. Wind & \multirow{11}{*}{$\begin{array}{l}\text { U.S. Wind, a subsidiary of the Italian developer Renexia, won the } \\
\text { competitive lease auction for the two Maryland wind energy areas. The } \\
\text { company is looking at a project size of } 500 \mathrm{MW} \text { to constrain it to areas } \\
\text { with water depths of no more than } 26 \text { meters. U.S. Wind started } \\
\text { conducting geotechnical and geophysical surveys on site in summer } \\
2015 \text {. }\end{array}$} \\
\hline State & Maryland & \\
\hline Jurisdiction & Federal & \\
\hline Status & Planning - Site Control & \\
\hline Capacity (MW) & 500 & \\
\hline Turbines (\#) & TBA & \\
\hline Average Distance to Shore (km) & 24 & \\
\hline Average Water Depth (m) & 25 & \\
\hline Turbine Rating (MW) & TBA & \\
\hline Foundation Type & Monopile & \\
\hline Target COD & 2020 & \\
\hline
\end{tabular}




\section{Appendix D. U.S. Offshore Wind Projects: Early-Stage Planning (Without Site Control)}

Table D-1. U.S. Offshore Wind Projects in the Early-Stage (Without Site Control) Phase

\begin{tabular}{|c|c|c|}
\hline \multicolumn{2}{|l|}{ Project: Oahu Northwest } & \multirow{2}{*}{$\begin{array}{l}\text { Status } \\
\text { AW Hawaii filed an unsolicited lease request to the Bureau of Ocean }\end{array}$} \\
\hline Developer & AW Hawaii, LLC & \\
\hline State & Hawaii & \multirow{10}{*}{$\begin{array}{l}\text { Energy Management (BOEM) in February } 2015 \text { to develop two offshore } \\
\text { wind projects off the coast of Oahu. BOEM made the determination that AW } \\
\text { Hawaii Wind, LLC is legally, financially, and technically qualified to hold an } \\
\text { Outer Continental Shelf (OCS) lease and will publish a Request for } \\
\text { Information (RFI) to determine whether there is competitive interest in the } \\
\text { lease area for this project site known as Oahu Northwest. }\end{array}$} \\
\hline Jurisdiction & Federal & \\
\hline Status & Planning - Early Stage & \\
\hline Capacity (MW) & 408 & \\
\hline Turbines (\#) & 51 & \\
\hline Average Distance to Shore (km) & 19 & \\
\hline Average Water Depth $(\mathrm{m})$ & 850 & \\
\hline Turbine Rating (MW) & 8 & \\
\hline Foundation Type & Semisubmersible & \\
\hline Target COD & 2020 & \\
\hline \multicolumn{2}{|l|}{ Project: Oahu Southwest } & \multirow{12}{*}{$\begin{array}{l}\text { Status } \\
\text { AW Hawaii filed an unsolicited lease request to BOEM in February } 2015 \text { to } \\
\text { develop two offshore wind projects off the coast of Oahu. BOEM made the } \\
\text { determination that AW Hawaii Wind, LLC is legally, financially, and } \\
\text { technically qualified to hold an OCS lease and will publish an RFI to } \\
\text { determine whether there is competitive interest in the lease area for this } \\
\text { project site known as Oahu Southwest. }\end{array}$} \\
\hline Developer & AW Hawaii, LLC & \\
\hline State & Hawaii & \\
\hline Jurisdiction & Federal & \\
\hline Status & Planning - Early Stage & \\
\hline Capacity (MW) & 408 & \\
\hline Turbines (\#) & 51 & \\
\hline Average Distance to Shore (km) & 27 & \\
\hline Average Water Depth (m) & 600 & \\
\hline Turbine Rating (MW) & 8 & \\
\hline Foundation Type & Semisubmersible & \\
\hline Target COD & 2020 & \\
\hline
\end{tabular}




\begin{tabular}{|c|c|}
\hline \multicolumn{2}{|c|}{ Project: Kitty Hawk Wind Energy Area (WEA) } \\
\hline Developer & To Be Determined (TBD) \\
\hline State & North Carolina \\
\hline Jurisdiction & Federal \\
\hline Status & Planning - Early Stage \\
\hline Capacity (MW) & 1,486 \\
\hline Turbines (\#) & To Be Announced (TBA) \\
\hline Average Distance to Shore (km) & 38 \\
\hline Average Water Depth (m) & 30 \\
\hline Turbine Rating (MW) & TBA \\
\hline Foundation Type & TBA \\
\hline Target COD & TBA \\
\hline \multicolumn{2}{|l|}{ Project: Wilmington West WEA } \\
\hline Developer & TBD \\
\hline State & North Carolina \\
\hline Jurisdiction & Federal \\
\hline Status & Planning - Early Stage \\
\hline Capacity (MW) & 626 \\
\hline Turbines (\#) & TBA \\
\hline Average Distance to Shore (km) & 19 \\
\hline Average Water Depth (m) & 30 \\
\hline Turbine Rating (MW) & TBA \\
\hline Foundation Type & TBA \\
\hline Target COD & TBA \\
\hline \multicolumn{2}{|l|}{ Project: Wilmington East WEA } \\
\hline Developer & TBD \\
\hline State & North Carolina \\
\hline Jurisdiction & Federal \\
\hline Status & Planning - Early Stage \\
\hline Capacity (MW) & 1,622 \\
\hline Turbines (\#) & TBA \\
\hline Average Distance to Shore (km) & 28 \\
\hline Average Water Depth (m) & 30 \\
\hline Turbine Rating (MW) & TBA \\
\hline Foundation Type & TBA \\
\hline Target COD & TBA \\
\hline
\end{tabular}

Status

BOEM published a revised Environmental Assessment for the North Carolina wind energy areas (WEAs) in September 2015 and found no significant environmental or socioeconomic impacts. The agency will now hold a meeting with the North Carolina Renewable Energy Task Force to discuss its proposed approach for competitive auction. After considering task force input, BOEM will then publish a Proposed Sale Notice in the Federal Register.

\section{Status}

BOEM published a revised Environmental Assessment for the North Carolina WEAs in September 2015 and found no significant environmental or socioeconomic impacts. The agency will now hold a meeting with the North Carolina Renewable Energy Task Force to discuss its proposed approach for competitive auction. After considering task force input, BOEM will then publish a Proposed Sale Notice in the Federal Register.

\section{Status}

BOEM published a revised Environmental Assessment for the North Carolina WEAs in September 2015 and found no significant environmental or socioeconomic impacts. The agency will now hold a meeting with the North Carolina Renewable Energy Task Force to discuss its proposed approach for competitive auction. After considering task force input, BOEM will then publish a Proposed Sale Notice in the Federal Register. 


\begin{tabular}{|c|c|}
\hline \multicolumn{2}{|l|}{ Project: New Jersey North } \\
\hline Developer & TBD \\
\hline State & New Jersey \\
\hline Jurisdiction & Federal \\
\hline Status & Planning - Early Stage \\
\hline Capacity (MW) & 2,226 \\
\hline Turbines (\#) & TBA \\
\hline Average Distance to Shore (km) & 15 \\
\hline Average Water Depth (m) & 25 \\
\hline Turbine Rating (MW) & TBA \\
\hline Foundation Type & TBA \\
\hline Target COD & TBA \\
\hline \multicolumn{2}{|l|}{ Project: New Jersey South } \\
\hline Developer & TBD \\
\hline State & New Jersey \\
\hline Jurisdiction & Federal \\
\hline Status & Planning - Early Stage \\
\hline Capacity (MW) & 1,948 \\
\hline Turbines (\#) & TBA \\
\hline Average Distance to Shore (km) & 15 \\
\hline Average Water Depth $(\mathrm{m})$ & 24 \\
\hline Turbine Rating (MW) & TBA \\
\hline Foundation Type & TBA \\
\hline Target COD & TBA \\
\hline \multicolumn{2}{|l|}{ Project: New York Call Area } \\
\hline Developer & TBD \\
\hline State & New York \\
\hline Jurisdiction & Federal \\
\hline Status & Planning - Early Stage \\
\hline Capacity (MW) & 987 \\
\hline Turbines (\#) & TBA \\
\hline Average Distance to Shore (km) & 35 \\
\hline Average Water Depth (m) & 30 \\
\hline Turbine Rating (MW) & TBA \\
\hline Foundation Type & TBA \\
\hline Target COD & TBA \\
\hline
\end{tabular}

Status

BOEM published a Proposed Sale Notice for the New Jersey WEA in July 2014 and confirmed that it intends to hold a competitive auction in fall 2015.

\section{Status}

BOEM published a Proposed Sale Notice for the New Jersey WEA in July 2014 and confirmed that it intends to hold a competitive auction in fall 2015.

\section{Status}

BOEM is working with the New York Intergovernmental Renewable Energy Task Force to identify potential WEAs in New York. The agency published a Notification of Intent to prepare an Environmental Assessment for the call area in May 2014. 


\section{Appendix E. Global Proposed Full-Scale Floating Projects Through 2020}

Table E-1. Proposed Full-Scale Floating Projects Worldwide (Through 2020)

\begin{tabular}{|c|c|c|c|c|c|c|c|c|c|}
\hline Project & $\begin{array}{c}\text { Lead } \\
\text { Organization }\end{array}$ & Status & Country & $\begin{array}{c}\text { Turbine } \\
\text { Capacity } \\
\text { (MW) }\end{array}$ & $\begin{array}{l}\text { Project } \\
\text { Capacity } \\
\text { (MW) }\end{array}$ & $\begin{array}{l}\text { Water } \\
\text { Depth } \\
\text { (m) }\end{array}$ & $\begin{array}{l}\text { Foundation } \\
\text { Type }\end{array}$ & $\begin{array}{l}\text { Year } \\
\text { Online }\end{array}$ & Description \\
\hline Hywind Demo & Statoil & Installed & NO & 2.3 & 2.3 & 220 & Spar & 2009 & $\begin{array}{l}\text { First full-scale floating turbine } \\
\text { (Siemens) on a Hywind spar } \\
\text { foundation }\end{array}$ \\
\hline $\begin{array}{l}\text { WindFloat } \\
\text { Atlantic I }\end{array}$ & $\begin{array}{l}\text { Principle } \\
\text { Power, Inc. }\end{array}$ & Installed & PT & 2.0 & 2.0 & 50 & Semisubmersible & 2011 & $\begin{array}{c}\text { Second full-scale turbine (Vestas) } \\
\text { on a three-column WindFloat } \\
\text { semisubmersible foundation } \\
\text { (Principle Power) }\end{array}$ \\
\hline $\begin{array}{l}\text { Kabashima/ } \\
\text { Goto }\end{array}$ & MOE & Installed & $J P$ & 2.0 & 2.0 & 91 & Spar & 2013 & $\begin{array}{l}\text { Two-MW Hitachi turbine on a hybrid } \\
\text { concrete-steel spar foundation }\end{array}$ \\
\hline $\begin{array}{l}\text { Fukushima } \\
\text { Forward I }\end{array}$ & METI & Installed & JP & 2.0 & 2.0 & 120 & Semisubmersible & 2013 & $\begin{array}{l}\text { Two-MW turbine (Hitachi) on a four- } \\
\text { column semisubmersible foundation } \\
\text { (Mitsui), as well as a 66-kV floating } \\
\text { substation on an advanced spar } \\
\text { foundation (Japan Marine United) }\end{array}$ \\
\hline $\begin{array}{l}\text { Fukushima } \\
\text { Forward II }\end{array}$ & METI & $\begin{array}{c}\text { Under } \\
\text { Construction }\end{array}$ & JP & $7.0 ; 5.0$ & 12 & 120 & $\begin{array}{l}\text { Semisubmersible; } \\
\text { Spar }\end{array}$ & $\begin{array}{c}2015 / \\
2016\end{array}$ & $\begin{array}{l}\text { Seven-MW turbine (MHI-Vestas) on } \\
\text { a V-shaped semisubmersible } \\
\text { foundation (MHI) and a 5-MW } \\
\text { turbine (Hitachi) on an advanced } \\
\text { spar foundation that incorporates } \\
\text { heave plates (Japan Marine United) }\end{array}$ \\
\hline FLOATGEN & Ideol; Adwen & Approved & $\mathrm{FR}$ & 2.0 & 2.0 & 45 & Semisubmersible & 2016 & $\begin{array}{l}\text { Two-MW turbine (Gamesa) on a } \\
\text { concrete semisubmersible } \\
\text { foundation featuring damping pool } \\
\text { technology (Ideol) }\end{array}$ \\
\hline $\begin{array}{l}\text { GICON SOF } \\
\text { Pilot }\end{array}$ & GICON & Approved & DE & 2.3 & 2.3 & 20 & $\begin{array}{l}\text { Tension-Leg } \\
\text { Platform }\end{array}$ & 2016 & $\begin{array}{l}\text { A 2.3-MW turbine (Siemens) on a } \\
\text { tension-leg platform (GICON); likely } \\
\text { to be the first operating wind turbine } \\
\text { on this type of platform in the world }\end{array}$ \\
\hline
\end{tabular}




\begin{tabular}{|c|c|c|c|c|c|c|c|c|c|}
\hline Project & $\begin{array}{c}\text { Lead } \\
\text { Organization }\end{array}$ & Status & Country & $\begin{array}{c}\text { Turbine } \\
\text { Capacity } \\
\text { (MW) }\end{array}$ & $\begin{array}{l}\text { Project } \\
\text { Capacity } \\
\text { (MW) }\end{array}$ & $\begin{array}{l}\text { Water } \\
\text { Depth } \\
\text { (m) }\end{array}$ & $\begin{array}{l}\text { Foundation } \\
\text { Type }\end{array}$ & $\begin{array}{l}\text { Year } \\
\text { Online }\end{array}$ & Description \\
\hline $\begin{array}{l}\text { Hywind } \\
\text { Scotland }\end{array}$ & Statoil & Permitting & UK & 6.0 & 30 & 100 & Spar & 2017 & $\begin{array}{l}\text { Five 6-MW Siemens turbines on } \\
\text { Hywind spars (Statoil) in Scotland }\end{array}$ \\
\hline $\begin{array}{l}\text { WindFloat } \\
\text { Atlantic II }\end{array}$ & $\begin{array}{l}\text { Principle } \\
\text { Power }\end{array}$ & Permitting & PT & $6.0-8.0$ & 25 & 100 & Semisubmersible & 2017 & $\begin{array}{l}\text { Three- to four-turbine array on a } \\
\text { WindFloat semisubmersible } \\
\text { (Principle Power) }\end{array}$ \\
\hline VERTIWIND & $\begin{array}{l}\text { Technip; } \\
\text { Nenuphar }\end{array}$ & Approved & $\mathrm{FR}$ & 2.0 & 2.0 & 50 & Semisubmersible & 2017 & $\begin{array}{l}\text { Two-MW vertical-axis turbine on a } \\
\text { semisubmersible foundation }\end{array}$ \\
\hline SEA REED & DCNS; Alstom & Planning & FR & 6.0 & 12 & 70 & Semisubmersible & 2018 & $\begin{array}{c}\text { Two 6-MW Alstom turbines on steel } \\
\text { substructures (WindFlo) }\end{array}$ \\
\hline $\begin{array}{l}\text { WindFloat } \\
\text { Pacific }\end{array}$ & $\begin{array}{l}\text { Principle } \\
\text { Power }\end{array}$ & Permitting & US & $6.0-8.0$ & 30 & 350 & Semisubmersible & 2018 & $\begin{array}{l}\text { Up-to-25-MW project on WindFloat } \\
\text { semisubmersibles (Principle Power) } \\
\text { off Coos Bay, Oregon }\end{array}$ \\
\hline Kincardine & $\begin{array}{l}\text { Pilot Offshore } \\
\text { Renewables }\end{array}$ & Permitting & UK & $6.0-8.0$ & 50 & 100 & Semisubmersible & 2017 & $\begin{array}{c}\text { Proposed } 50- \\
\text { MW project using WindFloat } \\
\text { semisubmersibles (Principle Power) }\end{array}$ \\
\hline Aqua Ventus I & DeepCWind & Permitting & US & 6.0 & 12 & 100 & Semisubmersible & 2018 & $\begin{array}{c}\text { Two 6-MW turbines on a concrete } \\
\text { semisubmersible foundation and } \\
\text { composite tower; a } 1 / 8^{\text {th }} \text {-scale } \\
\text { prototype was demonstrated in the } \\
\text { Gulf of Maine in } 2013\end{array}$ \\
\hline Dounreay & $\begin{array}{l}\text { Highland and } \\
\text { Islands } \\
\text { Enterprise }\end{array}$ & Planning & UK & $6.0-8.0$ & 30 & 85 & Floating & 2018 & $\begin{array}{l}\text { DBD Systems Eco-tension-leg } \\
\text { platform proposed for one or more } \\
\text { sites; combines a concrete tension- } \\
\text { leg platform with a concrete gravity } \\
\text { anchor }\end{array}$ \\
\hline $\begin{array}{l}\text { Oahu NW } \\
\text { Lease } \\
\text { Request }\end{array}$ & $\begin{array}{l}\text { AW Hawaii } \\
\text { Wind, LLC }\end{array}$ & Planning & US & $6.0-8.0$ & 408 & 850 & Semisubmersible & 2019 & $\begin{array}{c}\text { Developer submitted an unsolicited } \\
\text { lease application for a commercial } \\
\text { array with WindFloat } \\
\text { semisubmersibles in Hawaii }\end{array}$ \\
\hline
\end{tabular}




\begin{tabular}{|c|c|c|c|c|c|c|c|c|c|}
\hline Project & $\begin{array}{c}\text { Lead } \\
\text { Organization }\end{array}$ & Status & Country & $\begin{array}{c}\text { Turbine } \\
\text { Capacity } \\
\text { (MW) }\end{array}$ & $\begin{array}{l}\text { Project } \\
\text { Capacity } \\
\text { (MW) }\end{array}$ & $\begin{array}{c}\text { Water } \\
\text { Depth } \\
\text { (m) }\end{array}$ & $\begin{array}{c}\text { Foundation } \\
\text { Type }\end{array}$ & $\begin{array}{l}\text { Year } \\
\text { Online }\end{array}$ & Description \\
\hline $\begin{array}{l}\text { Oahu South } \\
\text { Lease } \\
\text { Request }\end{array}$ & $\begin{array}{l}\text { AW Hawaii } \\
\text { Wind, LLC }\end{array}$ & Planning & US & $6.0-8.0$ & 408 & 600 & Semisubmersible & 2019 & $\begin{array}{c}\text { Developer submitted an unsolicited } \\
\text { lease application for a commercial } \\
\text { array with WindFloat } \\
\text { semisubmersibles in Hawaii }\end{array}$ \\
\hline $\begin{array}{l}\text { Fukushima } \\
\text { Forward III }\end{array}$ & METI & Planning & JP & TBA & 100 & - & TBA & 2020 & $\begin{array}{c}\text { Large commercial installation that } \\
\text { expands upon the Fukushima } \\
\text { Demonstration Projects (Phase I } \\
\text { and II) }\end{array}$ \\
\hline
\end{tabular}

Note: Proposed commercial plans depend on the success of demonstration and precommercial arrays; also subject to political factors. Acronyms used in table: Minister of Environment (MOE); Ministry of Economic, Trade and Industry (METI); Mitsubishi Heavy Industries (MHI); To be announced (TBA). 


\section{Appendix F. Revenue Analysis for Recent European Subsidy Auctions}

Horns Rev III Revenue Analysis (Nominal USD)
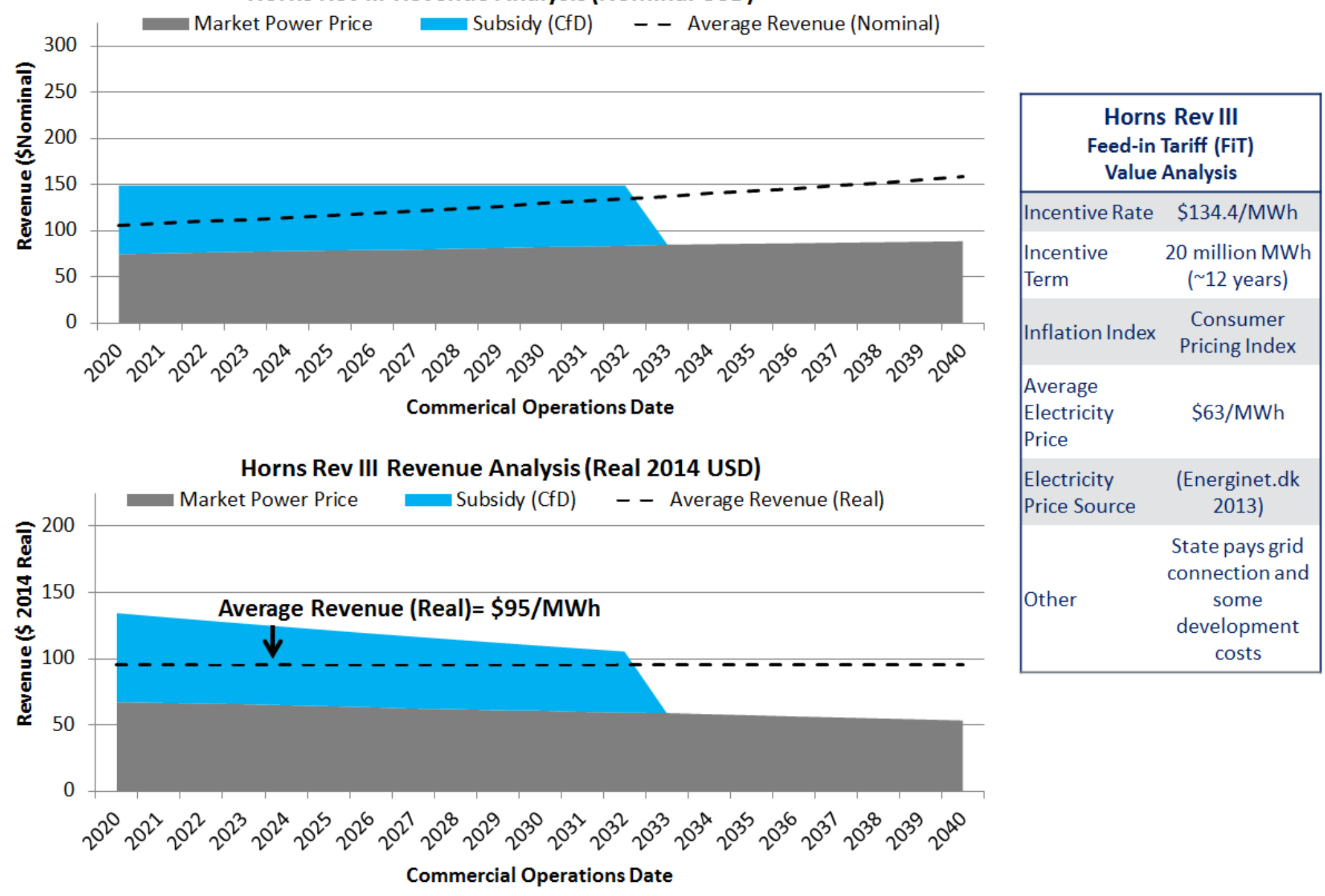

Figure F-1. Horns Rev III revenue analysis 


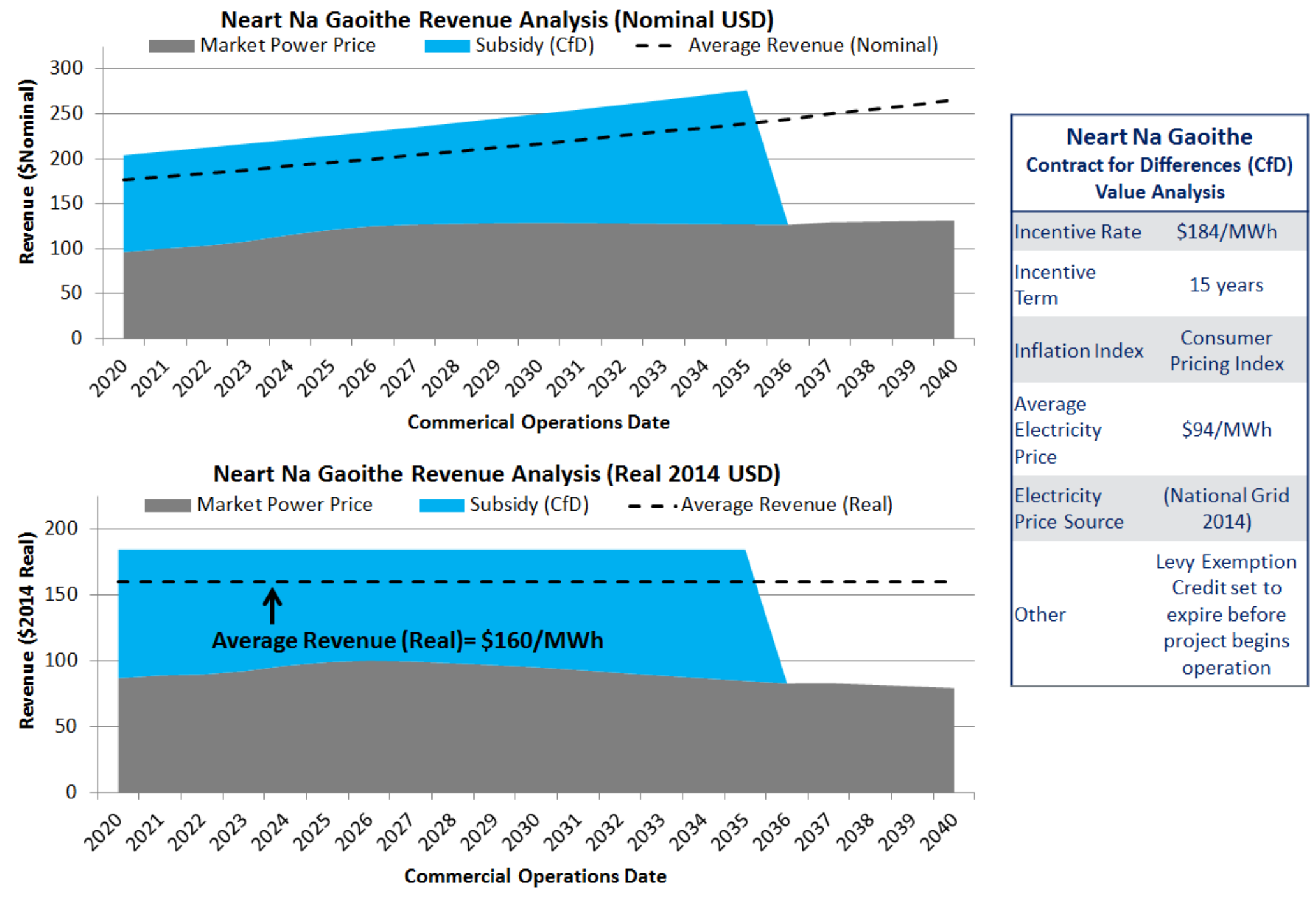

Figure F-2. Neart Na Gaoithe revenue analysis 

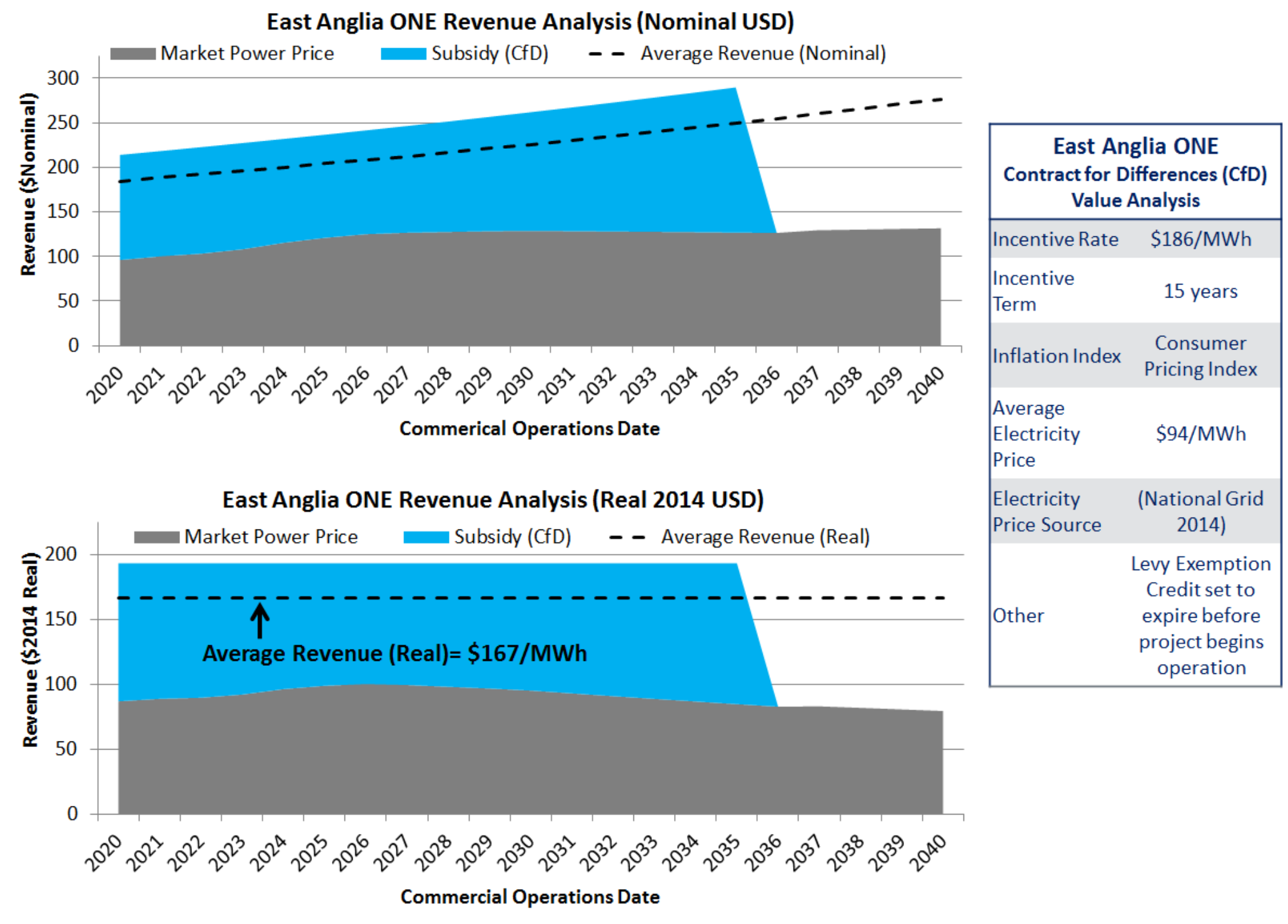

Figure F-3. East Anglia ONE revenue analysis 


\section{Wind Energy Websites}

\author{
U.S. Department of Energy Wind Program \\ wind.energy.gov
}

National Renewable Energy Laboratory

nrel.gov/wind

\section{American Wind Energy Association}

awea.org

\author{
Bureau of Ocean Energy Management \\ boem.gov/Renewable-Energy
}

International Energy Agency - Wind Agreement ieawind.org

European Wind Energy Association

ewea.org

\section{For more information on this report, contact:}

Aaron Smith, National Renewable Energy Laboratory

303-384-7191; Aaron.Smith@nrel.gov

Tyler Stehly, National Renewable Energy Laboratory

303-384-7190; Tyler.Stehly@nrel.gov

Walter Musial, National Renewable Energy Laboratory

303-384-6956; Walter.Musial@nrel.gov

On the Cover: Deepwater Wind begins the installation of the first of five steel jacket foundations at the 30-megawatt Block Island Wind

Farm offshore Rhode Island. Photo courtesy of Deepwater Wind

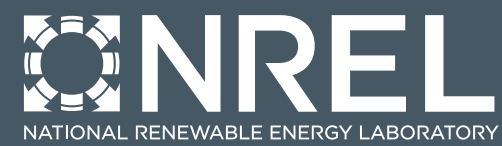

NREL is a national laboratory of the U.S. Department of Energy, Office of Energy Efficiency \& Renewable Energy, operated by the Alliance for Sustainable Energy, LLC.
This report is available at no cost from the National Renewable Energy Laboratory (NREL) at www.nrel.gov/publications.

NREL/TP-5000-64283 • September 2015

NREL prints on paper that contains recycled content. 